U.S. DEPARTMENT OF THE INTERIOR

U.S. GEOLOGICAL SURVEY

Prepared in cooperation with the

BUREAU OF LAND MANAGEMENT

\title{
Hydrologic Characteristics of the Agua Fria National Monument, Central Arizona, Determined from the Reconnaissance Study
}

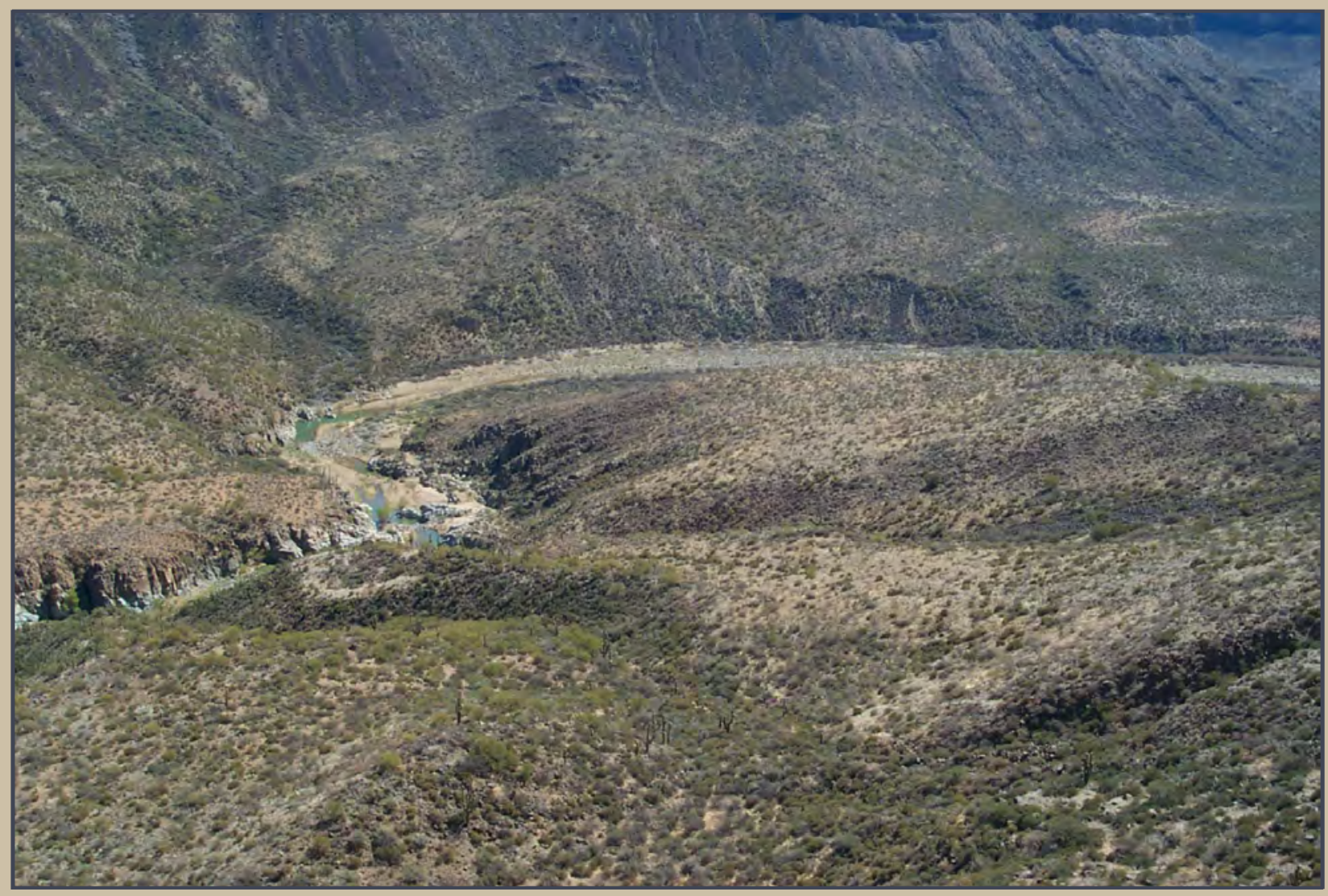

Scientific Investigations Report 2004-5163

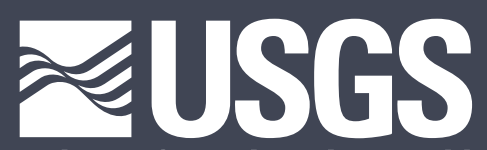


This page left blank intentionally. 


\section{Hydrologic Characteristics of the Agua Fria National Monument, Central Arizona, Determined from the Reconnaissance Study}

By John B. Fleming

Prepared in cooperation with the

BUREAU OF LAND MANAGEMENT

Scientific Investigations Report 2004-5163

U.S. Department of the Interior

U.S. Geological Survey 


\title{
U.S. Department of the Interior Gale A. Norton, Secretary
}

\author{
U.S. Geological Survey \\ Charles G. Groat, Director
}

\section{U.S. Geological Survey, Reston, Virginia: 2005}

For sale by U.S. Geological Survey, Information Services

Box 25286, Denver Federal Center

Denver, CO 80225-0286

Prepared by the Arizona Water Science Center, Tucson.

For more information about the USGS and its products:

Telephone: 1-888-ASK-USGS

World Wide Web: http://www.usgs.gov/

Any use of trade, product, or firm names in this publication is for descriptive purposes only and does not imply endorsement by the U.S. Government.

Although this report is in the public domain, permission must be secured from the individual copyright owners to reproduce any copyrighted materials contained within this report. 


\section{Contents}

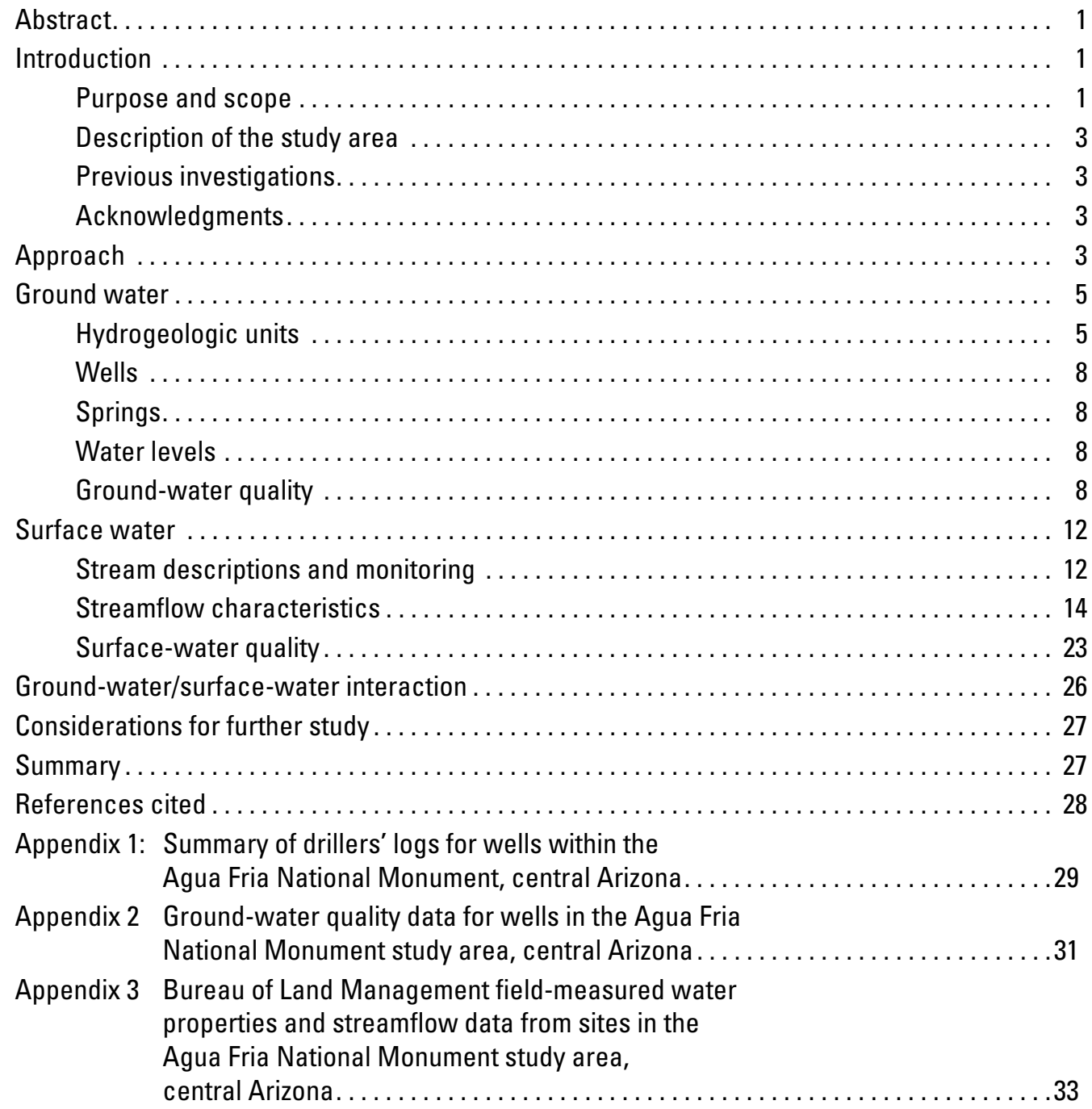




\section{Figures}

1-7. Maps showing:

1. Locations of the study area, Agua Fria National Monument, the U.S. Geological Survey streamflow-gaging station, and precipitation gages, central Arizona ......................... 2

2. Vegetation types in the Agua Fria National Monument study area, central Arizona .................................. 4

3. Geology and locations of wells for which a driller's log is available, Agua Fria National Monument study area,

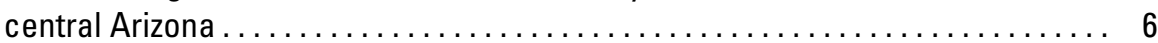

4. Locations of springs in the Agua Fria National Monument area,

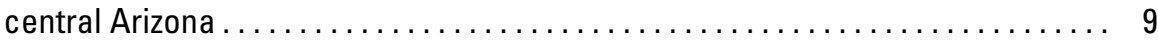

5. Potentiometric surface, 2003, Agua Fria National Monument area, central Arizona .................................... 11

6. Agua Fria River and major tributaries in the Agua Fria National Monument study area, central Arizona . ........................ 13

7. Surface-water sites in the Agua Fria National Monument study area, central Arizona, at which data were collected by the U.S. Geological Survey or the Bureau of Land Management, 1980-2002. . .

8-17. Graphs showing:

8. Mean monthly streamflow at Agua Fria River near Mayer,

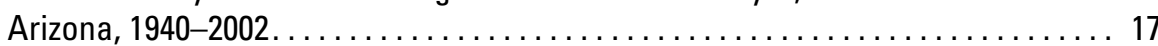

9. Mean daily streamflow at Agua Fria River near Mayer, Arizona, 1940-2002...................................... 17

10. Mean monthly streamflow at Agua Fria River near Rock Springs, Arizona, 1970-2002 . ............................ 17

11. Mean daily streamflow at Agua Fria River near Rock Springs, Arizona, 1970-2002 .......................... 17

12. Mean monthly precipitation at gages near the Agua Fria National Monument area, central Arizona . ......................................... 18

13. Annual peak streamflow at Agua Fria River near Mayer, Arizona, 1940-2002.................................. 19

14. Annual mean streamflow at Agua Fria River near Mayer, Arizona, 1940-2001................................ 19

15. Annual peak streamflow at Agua Fria River near Rock Springs, Arizona, 1920-2002 ........................... 20

16. Annual mean streamflow at Agua Fria River near Rock Springs, Arizona, 1971-2001

17. Streamflow of the Agua Fria River at the seepage study sites, Agua Fria National Monument, central Arizona, 


\section{Tables}

1. Springs in the Agua Fria National Monument study area, central Arizona . ........ 10

2. Field-measured water properties and discharge data from the Bureau of Land Management for springs in the Agua Fria National Monument

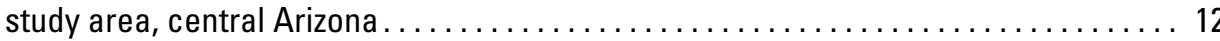

3. Lengths of perennial reaches of the Agua Fria River and tributaries of the Agua Fria River, Agua Fria National Monument study area, central Arizona ............................................ 14

4. U.S. Geological Survey streamflow-gaging stations on the Agua Fria River in the Agua Fria National Monument study area, central Arizona. ........... 14

5. Surface-water sites on the Agua Fria River in the Agua Fria National Monument study area, central Arizona, for which records were available in the U.S. Geological Survey National Water Information System, 2003

6. Surface-water sites in the Agua Fria National Monument study area, central Arizona, at which streamflow and field properties were measured by Bureau of Land Management staff, June 1992 to November 1998

7. Surface-water sites on the Agua Fria River in the Agua Fria National

Monument, central Arizona, at which streamflow, specific conductance, and temperature were measured during the

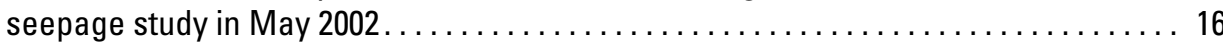

8. Precipitation gages in the Agua Fria National Monument study area, central Arizona ................................................. 18

9. Duration of mean daily flow, Agua Fria River near Mayer,

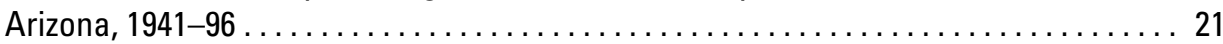

10. Duration of daily mean flow, Agua Fria River near Rock Springs, Arizona,

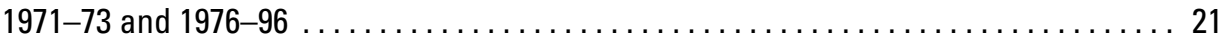

11. Magnitude and probability of high flow, Agua Fria River near

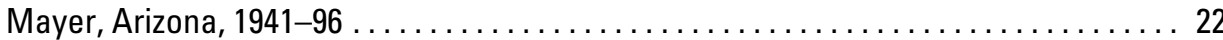

12. Magnitude and probability of high flow, Agua Fria River near

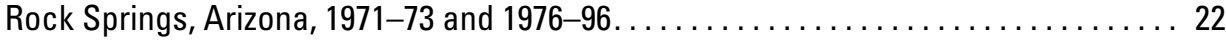

13. Magnitude and probability of low flow, Agua Fria River near

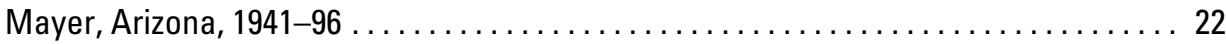

14. Magnitude and probability of low flow, Agua Fria River near Rock Springs, Arizona, 1971-73 and 1976-96........................ 23

15. Streamflow data from sites on the Agua Fria River in the Agua Fria National Monument study area, central Arizona, that were retrieved from the U.S. Geological Survey National Water

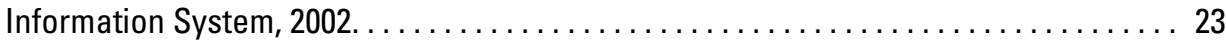

16. Streamflow of Agua Fria River at the seepage study sites, Agua Fria National Monument, central Arizona, May 2002.

17. Specific-conductance, $\mathrm{pH}$, and selected cation concentration data for sites on the Agua Fria River in the Agua Fria National Monument study area, central Arizona, that were retrieved from the U.S. Geological Survey National Water Information System, 2002

18. Average stream-property values at sites in the Agua Fria National Monument study area, central Arizona, measured by Bureau of Land Management staff, June 1992 to November 1998

19. Specific-conductance and temperature data for the seepage study sites along the Agua Fria River, Agua Fria National Monument, central Arizona, May 2002. 


\section{Conversion Factors and Datums}

\begin{tabular}{|c|c|c|}
\hline Multiply & By & To obtain \\
\hline \multicolumn{3}{|c|}{ Length } \\
\hline inch (in) & 2.54 & centimeter \\
\hline inch (in) & 25.4 & millimeter \\
\hline foot $(\mathrm{ft})$ & 0.3048 & meter \\
\hline mile (mi) & 1.609 & kilometer \\
\hline \multicolumn{3}{|c|}{ Area } \\
\hline acre & 4,047 & square meter \\
\hline acre & 0.4047 & hectare \\
\hline acre & 0.004047 & square kilometer \\
\hline square foot $\left(\mathrm{ft}^{2}\right)$ & 929.0 & square centimeter \\
\hline square foot $\left(\mathrm{ft}^{2}\right)$ & 0.09290 & square meter \\
\hline square mile $\left(\mathrm{mi}^{2}\right)$ & 2.590 & square kilometer \\
\hline \multicolumn{3}{|c|}{ Volume } \\
\hline acre-foot (acre-ft) & 0.001233 & cubic hectometer \\
\hline cubic foot per second $\left(\mathrm{ft}^{3} / \mathrm{s}\right)$ & 0.02832 & cubic meter per second \\
\hline
\end{tabular}

Temperature in degrees Celsius $\left({ }^{\circ} \mathrm{C}\right)$ may be converted to degrees Fahrenheit $\left({ }^{\circ} \mathrm{F}\right)$ as follows:

$$
\mathrm{F}=\left(1.8^{\circ} \mathrm{C}\right)+32
$$

Vertical coordinate information is referenced to the National Geodetic Vertical Datum of 1929 (NGVD 29) - a geodetic datum derived from a general adjustment of the first-order level nets of both the United States and Canada, formerly called Sea Level Datum of 1929; horizontal coordinate information is referenced to the North American Datum of 1927 (NAD 27). Altitude, as used in this report, refers to distance above or below NGVD 29.

\section{ABBREVIATED WATER-QUALITY UNITS}

Chemical concentration and water temperature are given only in metric units. Chemical concentration in water is given in milligrams per liter (mg/L) or micrograms per liter $(\mu \mathrm{g} / \mathrm{L})$. Milligrams per liter is a unit expressing the solute mass (milligrams) per unit volume (liter) of water. One thousand micrograms per liter is equivalent to 1 milligram per liter. For concentrations less than 7,000 milligrams per liter, the numerical value is about the same as for concentrations in parts per million. Specific conductance is given in microsiemens per centimeter at 25 degrees Celsius $\left(\mu \mathrm{S} / \mathrm{cm}\right.$ at $\left.25^{\circ} \mathrm{C}\right)$. 
WELL-NUMBERING AND NAMING SYSTEM

WELL (A-11-02)25bdd

R. 2 E.

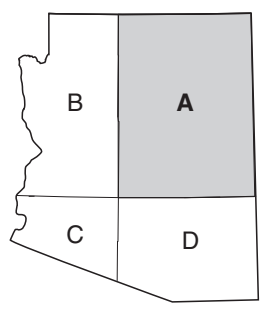

\begin{tabular}{|c|c|c|c|c|c|}
\hline 6 & 5 & 4 & 3 & 2 & 1 \\
\hline 7 & 8 & 9 & 10 & 11 & 12 \\
\hline 18 & 17 & 16 & 15 & 14 & 13 \\
\hline 19 & 20 & 21 & 22 & 23 & 24 \\
\hline 30 & 29 & 28 & 27 & 26 & 25 \\
\hline 31 & 32 & 33 & 34 & 35 & 36 \\
\hline
\end{tabular}

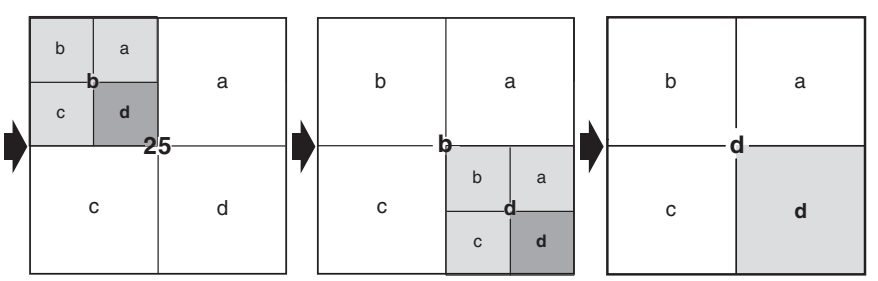

Quadrant A, Township 11 North, Range 2 East, section 25, 160-acre tract b, 40-acre tract d, 10-acre tract d

The well numbers used by the U.S. Geological Survey in Arizona are in accordance with the Bureau of Land Management's system of land subdivision. The land survey in Arizona is based on the Gila and Salt River Meridian and Base Line, which divide the State into four quadrants that are designated by capital letters A, B, C, and D in a counterclockwise direction, beginning in the northeast quarter. The first digit of a well number indicates the township, the second the range, and the third the section in which the well is situated. The lowercase letters a, b, c, and d after the section number indicate the well location within the section. The first letter denotes a particular 160-acre tract, the second the 40 -acre tract, and the third the 10-acre tract. These letters also are assigned in a counterclockwise direction, beginning in the northeast quarter. If the location is known within the 10 -acre tract, three lowercase letters are shown in the well number. Where more than one well is within a 10 -acre tract, consecutive numbers beginning with 1 are added as suffixes. In the example shown, well number (A-11-02)25bdd designates the well as being in the SE1/4, SE1/4, NW1/4, section 25, Township 11 North, and Range 2 East. 
This page left blank intentionally. 


\section{Hydrologic Characteristics of the Agua Fria National Monument, Central Arizona, Determined from the Reconnaissance Study}

By John B. Fleming

\section{Abstract}

Hydrologic conditions in the newly created Agua Fria National Monument were characterized on the basis of existing hydrologic and geologic information, and streamflow data collected in May 2002. The study results are intended to support the Bureau of Land Management's future water-resource management responsibilities, including quantification of a Federal reserved water right within the monument. This report presents the study results, identifies data deficiencies, and describes specific approaches for consideration in future studies.

Within the Agua Fria National Monument, the Agua Fria River flows generally from north to south, traversing almost the entire 23-mile length of the monument. Streamflow has been measured continuously at a site near the northern boundary of the monument since 1940. Streamflow statistics for this site, and streamflow measurements from other sites along the Agua Fria River, indicate that the river is perennial in the northern part of the monument but generally is intermittent in downstream reaches. The principal controls on streamflow along the river within the monument appear to be geology, the occurrence and distribution of alluvium, inflow at the northern boundary and from tributary canyons, precipitation, and evapotranspiration. At present, (2004) there is no consistent surface-water quality monitoring program being implemented for the monument.

Ground-water recharge within the monument likely results from surface-water losses and direct infiltration of precipitation. Wells are most numerous in the Cordes Junction and Black Canyon City areas. Only eight wells are within the monument. Ground-water quality data for wells in the monument area consist of specific-conductance values and fluoride concentrations. During the study, ground-water quality data were available for only one well within the monument. No ground-water monitoring program is currently in place for the monument or surrounding areas.

\section{Introduction}

The Agua Fria National Monument is a recently (2000) designated preserve in central Arizona (fig. 1) that is managed by the Bureau of Land Management (BLM). Information was needed to provide a basis for development of resource-management strategies. In 2002 the U.S. Geological Survey (USGS), in cooperation with the BLM, began a hydrologic characterization of the monument. This reconnaissance study compiled information that can be used by the BLM to support future water-resource management responsibilities within the monument, including quantification of a Federal Reserve water right.

\section{Purpose and Scope}

The purpose of this report is to present existing hydrologic and geologic information, supplemented with new streamflow data, and describe the surface-water and ground-water conditions in the monument on the basis of this information. The report describes the ground-water flow system and its interaction with streams within the monument and in adjacent areas, and in general terms, the surface-water flow regime. The study results will enable the BLM to design and implement detailed hydrologic and hydrogeologic datacollection programs. 


\section{Hydrologic Characteristics of the Agua Fria National Monument, Central Arizona, Reconnaissance Study}

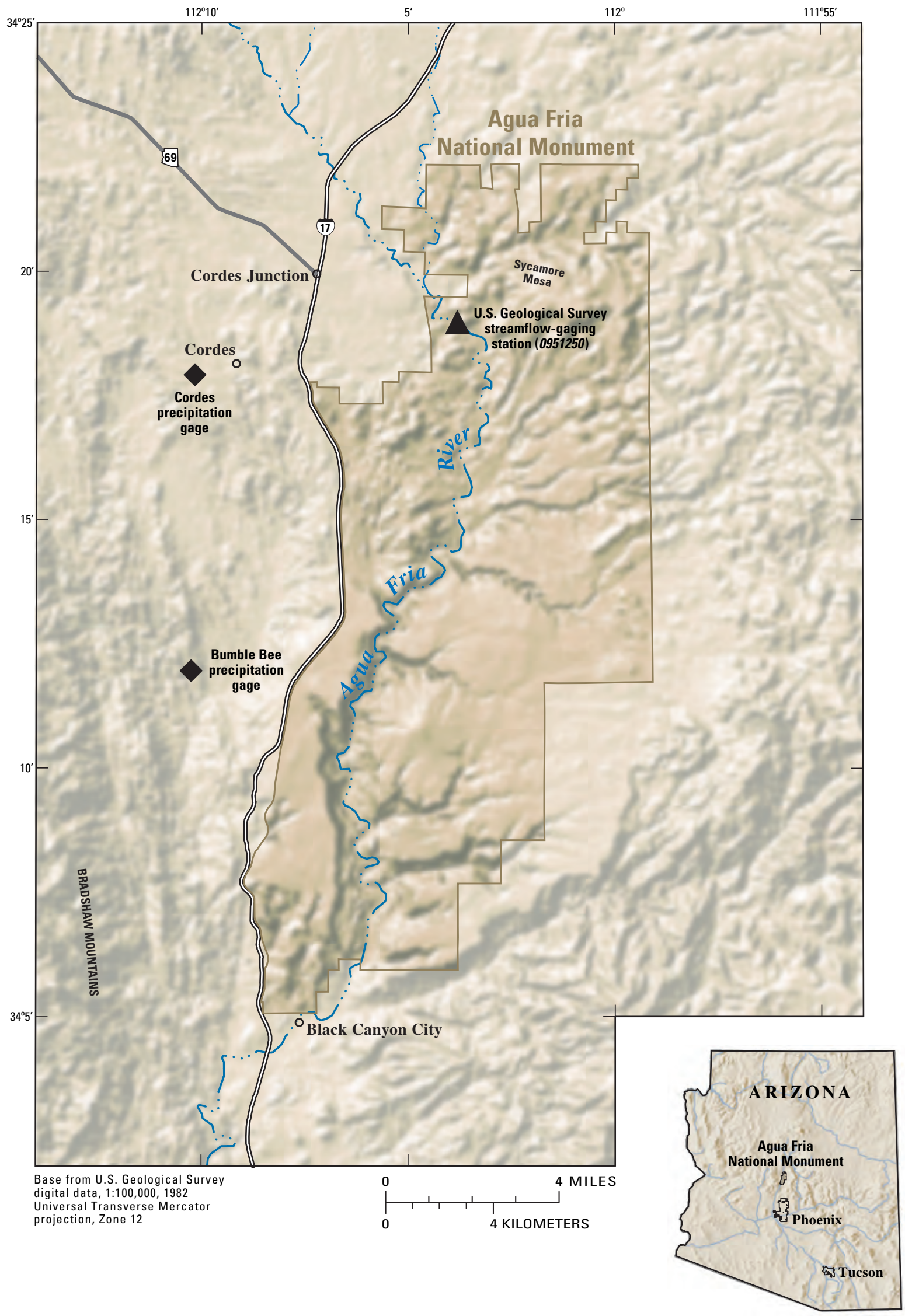

Figure 1. Locations of the study area, Agua Fria National Monument, the U.S. Geological Survey streamflow-gaging station, and precipitation gages, central Arizona. 


\section{Description of the Study Area}

The Agua Fria National Monument lies within the Transition Zone between the Basin and Range and Colorado Plateau Physiographic Provinces (Fenneman, 1931) about $40 \mathrm{mi}$ north of Phoenix, Arizona (fig. 1). It encompasses about 71,000 acres within the Agua Fria watershed and includes $23 \mathrm{mi}$ of perennial and intermittent reaches of the Agua Fria River that support highly valued riparian areas. The study area was extended beyond the monument boundaries to include information on hydrologic and geologic factors in areas adjacent to the monument that, in part, control hydrologic conditions within the monument.

Within the monument, the Agua Fria River generally flows from north to south, traversing almost the entire length of the monument (fig. 1). The geology within the monument is closely reflected in the terrain. Precambrian granitic rocks and schist in the Bradshaw Mountains bordering the western margin of the monument are exposed as rugged, deep canyons with steep slopes. To the east, surficial units are mostly Tertiary and Quaternary basaltic rocks underlain by Precambrian granitic rocks and schist (Wilson, 1988). These areas are typified by broad, gently sloping mesas separated by deeply incised, steep side canyons. In the southern half of the monument, the river has carved a deep canyon through the basaltic rocks and into the Precambrian granitic rocks and schist that, in some places, exceeds 1,000 ft. Land-surface altitude within the monument ranges from about 2,050 ft along the Agua Fria River near Black Canyon City to about 4,600 ft in the northern hills near Sycamore Mesa.

The semiarid climate in the monument is characterized by hot and relatively dry summers and mild winters. Average seasonal high temperatures measured in Cordes, Arizona, northwest of the monument, range from $35^{\circ} \mathrm{C}$ in the summer to $13.9^{\circ} \mathrm{C}$ in the winter (Western Regional Climate Center, Desert Research Institute, 2004). Precipitation predominantly occurs during two periods. Summer monsoonal rains, which generally occur from July through September, are characterized by often intense, isolated thunderstorms. Winter precipitation from December through March is predominantly rain, but includes snow. Average annual precipitation within the monument probably is less than 20 inches. Precipitation amounts vary greatly with altitude; higher altitudes generally receive greater amounts (Sellers and Hill, 1974).

The varied geology and climate within the monument provide favorable habitat for a wide variety of desert plants including several species of grasses, mesquite, palo verde, yucca, and cacti, such as prickly pear and saguaro (fig. 2). Vegetated areas along the Agua Fria River contain mixed grasses, shrubs, and trees.

\section{Previous Investigations}

Although no detailed geologic mapping specific to the monument has been conducted, Anderson and Blacet (1972) provide detailed geology for most of the northern half of the monument. A less detailed map of Yavapai County was published by the Arizona Bureau of Mines (1958). Additional geologic data (Richard and others, 2000) are also available. Littin (1981) provided the first generalized description of the hydrogeologic conditions in the Agua Fria watershed. He described the major hydrogeologic units; produced maps showing locations of wells and springs, water-level conditions, and generalized direction of ground-water flow; and presented water-quality data. Wilson (1988) reported on the water resources in the northern part of the Agua Fria watershed and provided an updated description of the hydrogeologic conditions in the area that would eventually become the northern half of the monument. Partly in response to public concern over increased development in the watershed, Barnett and others (2003) provided a reassessment of the hydrogeologic conditions in the upper Agua Fria watershed with an emphasis on planning for sustainability of water resources.

\section{Acknowledgments}

Paul Summers and Jim Fogg (BLM, Denver, Colorado), and Lin Fehlman and Chris Horyza (BLM, Phoenix Field Office, Arizona) provided geographic information system (GIS) covers, maps, and water-quality and streamflow data, as well as thoughtful and valuable editorial comments on drafts of the manuscript. Kelly Ashton, Robert Fritzinger, and Fletcher Brinkerhoff, USGS, Tucson, Arizona, assisted with data collection.

\section{Approach}

Information was compiled from the Arizona Geological Survey, the USGS National Water Information System (NWIS), the BLM Phoenix Field Office archives, and databases maintained by the Arizona Departments of Environmental Quality and Water Resources, the Western Regional Climate Center in Reno, Nevada, and the Arizona Game and Fish Department. Information included bibliographic data, hydrologic data, spatial data sets, paper maps, published reports, and other relevant documents. 


\section{Hydrologic Characteristics of the Agua Fria National Monument, Central Arizona, Reconnaissance Study}

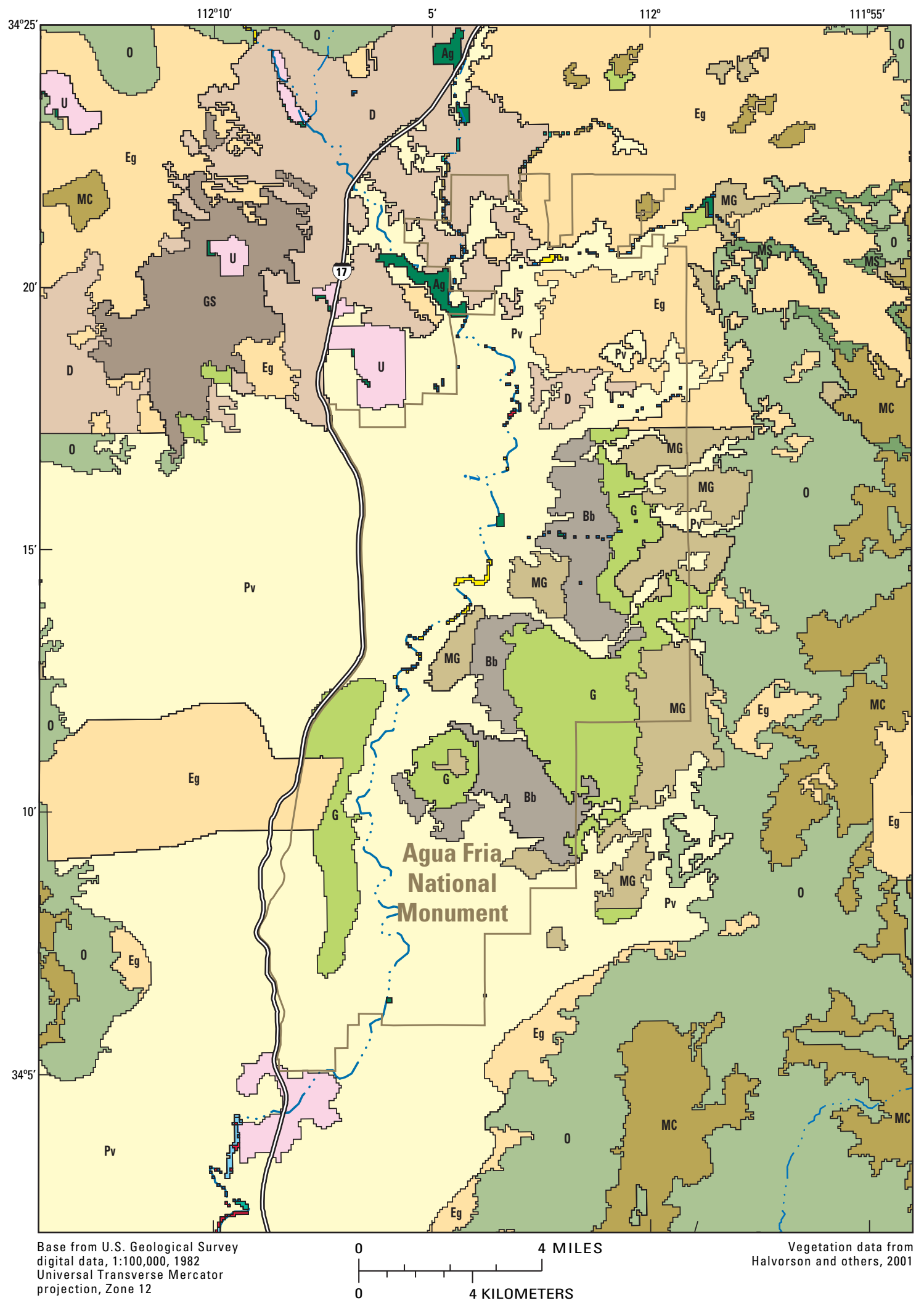

Figure 2. Vegetation types in the Agua Fria National Monument study area, central Arizona. 
EXPLANATION

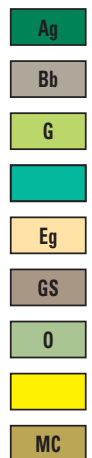

Agriculture

Blackbrush/mixed scrub

Mixed grass/mixed scrub

Riparian forest/mixed riparian scrub

Chaparral/mixed evergreen sclerophyll

Mixed chaparral/mixed grass/scrub complex

Chaparral/shrub live oak/pointleaf manzanita

Riparian/mixed riparian scrub

Mixed pinyon-juniper/mixed chaparral/scrub

Figure 2. Continued.

A reconnaissance field trip was conducted in March 2002 to develop a preliminary understanding of the physical setting. In May 2002, a seepage study was conducted during which streamflow, specific conductance, and temperature were measured at 14 sites along the Agua Fria River within the monument. Existing data were combined with these newly collected data to aid in the preliminary characterization of the surfacewater and ground-water hydrology of the study area.

\section{Ground Water}

The main water-bearing unit within the monument is the stream-channel alluvium, which is bounded by outcrops of igneous and metamorphic rocks. Although no thickness data exist for the alluvial aquifer along the river channel within the monument, the distance between bedrock outcrops bisected by the channel and evidence of high-volume scouring flows indicate that, in some areas, the cross-sectional area of the alluvium is probably less than a few hundred square feet. This is especially true where the river has incised the bedrock to form a deep canyon. Recharge to the alluvial aquifer probably is from infiltration of surface water and precipitation. Decreases in streamflow along the river in the monument indicate that surface water is being lost to the alluvial aquifer.

A secondary aquifer could comprise the igneous and metamorphic rock units that transmit water as a result of secondary porosity related to fracturing. The main source of recharge for these units likely is local precipitation that infiltrates directly into permeable zones associated with

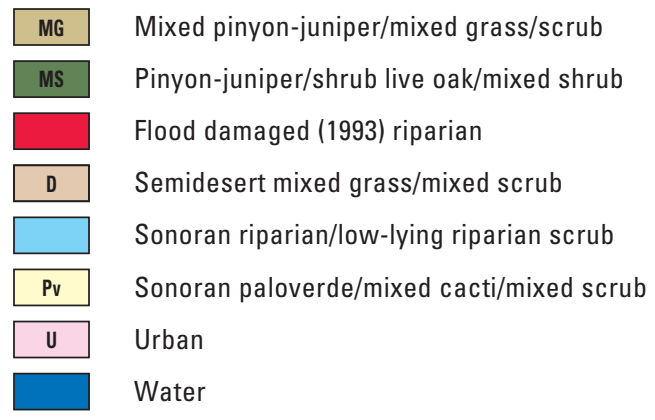

fracturing and indirectly though overlying alluvium. Ground water within these zones likely discharges at several springs in and near the monument.

\section{Hydrogeologic Units}

According to Richard and others (2000), geologic units in the study area vary in age from about 1.8 billion years for Proterozoic metamorphic rocks to modern for alluvial and eolian deposits (fig. 3). Along much of its length within the monument, the Agua Fria River has incised the Tertiary basaltic rocks, Tertiary sedimentary units, and Proterozoic granitic rocks that make up the river canyon. These rocks likely are the principal sources of alluvium within the canyon. On the basis of a review of drillers' logs, the alluvium ranges in size from silt to boulder, and in some areas, the alluvial thickness exceeds $150 \mathrm{ft}$. The areal extent and thickness of alluvium likely are the principal controls on the availability of usable ground water. The reported depths to water from the same drillers' logs range from an unknown height above land surface to $328 \mathrm{ft}$ below land surface.

Available geologic maps show no faults or other major structural features within the monument. Richard and others (2000) reported largely northwest-trending faults east and west of the monument, and northeasttrending faults northwest and southeast of the monument. The nearest of these faults, which offset only the Proterozoic rocks, are about $3 \mathrm{mi}$ east of the eastern monument boundary (fig. 3). 


\section{Hydrologic Characteristics of the Agua Fria National Monument, Central Arizona, Reconnaissance Study}

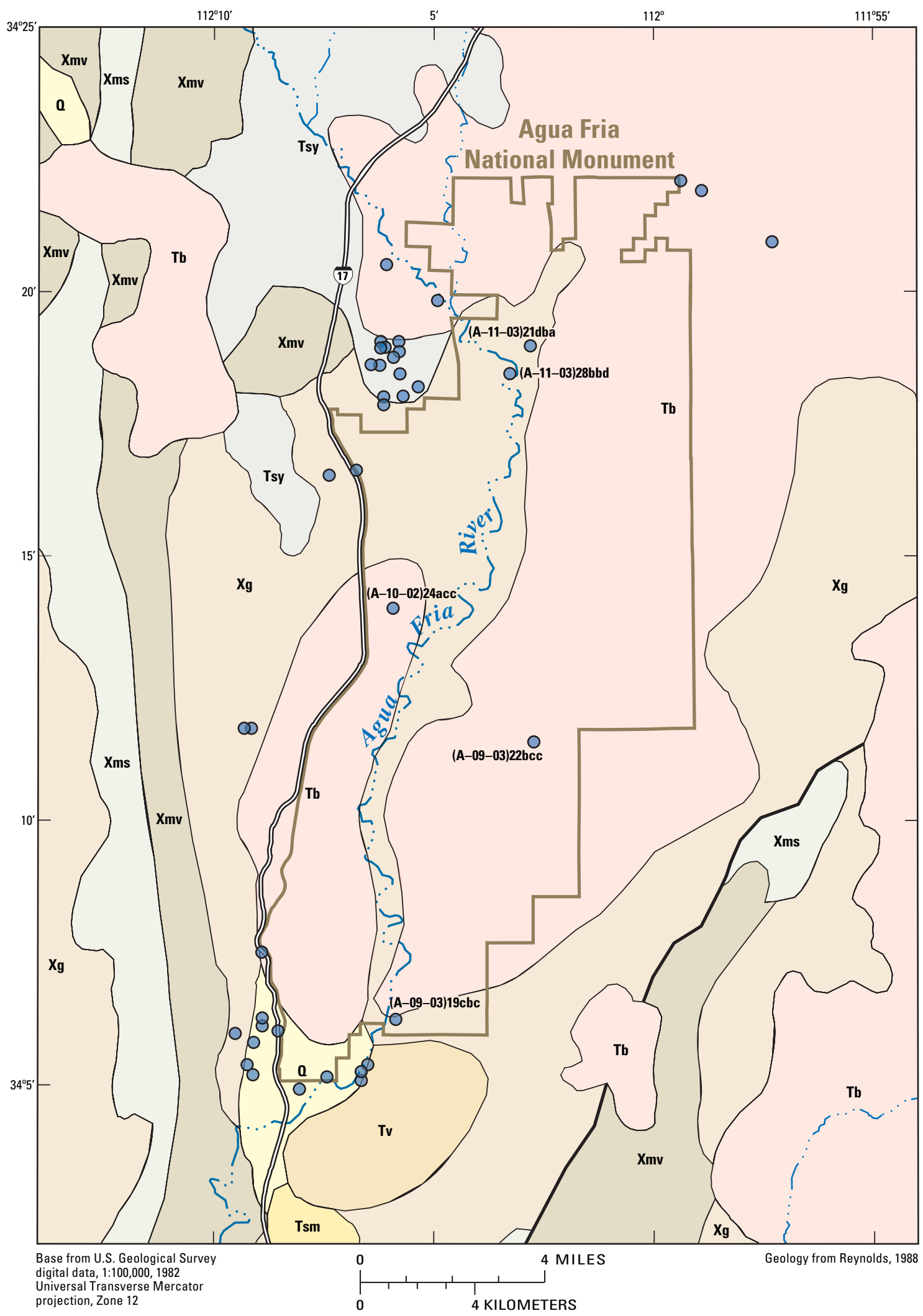

Figure 3. Geology and locations of wells for which a driller's log is available, Agua Fria National Monument study area, central Arizona. 
Ground Water 7

\section{EXPLANATION}

$0 \quad$ Surficial deposits - Alluvium in present-day valleys and piedmonts, eolian deposits, and local glacial deposits

Tsy Sedimentary rocks - Units deposited during and after late Tertiary normal faulting, sedimentary parts of Bidahochi Formation, and the Bouse Formation; commonly capped by patches of Quaternary surficial deposits

Tb Basaltic rocks - Units such as the Hickey Formation, erupted after most mid-Tertiary volcanism and tectonism.

HOLOCENE TO MIDDLE PLIOCENE

PLIOCENE TO MIDDLE MIOCENE

LATE TO MIDDLE MIOCENE

Tsm Sedimentary rocks - Deposited during mid-Tertiary orogenic activity in the Basin and Range Province and southwestern Transition Zone.

Tv Volcanic rocks - Silicic to mafic flows and pyroclastic rocks; includes some subvolcanic intrusions.

$\mathrm{Xg}$ Granitoid rocks - Granite, granodiorite, tonalite, quartz diorite, diorite, and gabbro; commonly foliated.

Xms Metasedimentary rocks

EARLY PROTEROZOIC

Xmv Metavolcanic rocks

Fault

Well for which a driller's log is available; labeled wells correspond to identifier in appendix 1

Figure 3. Continued. 


\section{Hydrologic Characteristics of the Agua Fria National Monument, Central Arizona, Reconnaissance Study}

On the basis of the distribution of low-permeability crystalline igneous and metamorphic basement rocks that separate ground-water flow systems, Wilson (1988) divided much of the Agua Fria watershed into three ground-water subareas: Lonesome Valley, Mayer, and Black Hills. Wilson (1988) provides generalized descriptions for the hydrogeologic rock units that make up the major aquifer in each of these subareas. The Black Hills subarea, which occupies most of the southeastern half of the watershed, includes the monument and adjacent areas. Within the monument, the hydrogeologic units are the Quaternary alluvium, Tertiary basaltic rocks, and the early Proterozoic granitic rocks.

The basaltic rocks into which tributary drainages are incised are higher in altitude than the alluvium, overlie granitic rocks, and crop out in the eastern half of the monument. Because the thickness of the basaltic rocks is unknown, the amount of water that could be moving through these rocks cannot easily be estimated. Basaltic rocks west of the river that underlie the southern half of the monument's western boundary have a limited extent due to erosional isolation and likely contribute little water to the alluvium.

\section{Wells}

Data obtained from the Arizona Department of Water Resources (ADWR) and USGS databases for wells in the study area include drillers' logs and information about well use, well location, water levels, and water quality. Of the 88 wells for which data were obtained, only 8 are within the monument. Many of the 88 wells are in the Cordes Junction and Black Canyon City areas and are private, domestic, or agricultural wells that are not routinely monitored for water levels or water quality.

Drillers' logs were obtained from the ADWR database for 39 wells in or near the monument (fig. 3 ). Of these 39 wells, 5 are within the monument. Most of the 39 wells are in the towns of Cordes and Black Canyon City as there is little ground-water development in rural areas. Drillers' logs generally are consistent with the mapped geology. In areas mapped as Quaternary surficial deposits, which include alluvium, drillers' logs showed that these deposits vary in thickness from $0 \mathrm{ft}$ to as much as $150 \mathrm{ft}$ and are typically underlain by metamorphic rocks including granite and schist (fig. 3). In areas mapped as Tertiary basaltic rocks, drillers' logs showed thicknesses in excess of $500 \mathrm{ft}$ in some areas. A summary of the five drillers' logs for wells within the monument is given in appendix 1 of this report.

\section{Springs}

Data obtained from the USGS Ground-Water Site Inventory (GWSI) database indicated four springs in the study area. Of these, only one (Badger Spring) is reported as being within the monument (fig. 4 and table 1). Data obtained from the BLM database indicated 24 springs in the study area (fig. 4 and table 1). There is disagreement, however, between the two databases with respect to the location of Badger Spring.

There are more springs in the northern part of the monument than in the southern part. In relation to the scale of the mapped geology in the area, many of the springs appear to issue from dissected areas within the Tertiary basaltic rocks and the early Proterozoic granitic rocks and metasedimentary units. Littin (1981) reported that most springs issuing from basaltic rocks are seasonal, whereas most springs issuing from granitic rocks and metasedimentary units are perennial; however, the means by which this conclusion was drawn are not clear.

\section{Water Levels}

Littin (1981) constructed a map of ground-water altitude and generalized direction of ground-water flow in the Agua Fria area. That work, however, had little or no detailed information for the area that is now the monument. As a follow-up to the work of Littin (1981), León and Ferré (2003) constructed a ground-water altitude map for the upper Agua Fria watershed using water levels measured between January 1962 and April 2002 at 363 wells (fig. 5). Although data are sparse for areas within the monument and east of the monument, the map shows that ground-water flow is generally from north to south and follows the longitudinal axis of the river channel. Water-level altitudes range from about $3,900 \mathrm{ft}$ near the northern boundary of the monument to about 2,000 ft near the southern boundary.

\section{Ground-Water Quality}

Water-quality data supplied by the BLM included measured discharge and field-measured water properties-specific conductance, dissolved solids, $\mathrm{pH}$, dissolved oxygen, turbidity, and temperature-for 19 springs (table 2). No clear correlation was evident between measured values and spring location. No waterquality data were available for springs inventoried in the USGS GWSI database.

Water-quality data were available for 22 of the 88 wells identified in the Agua Fria National Monument study area. These data consisted of specific-conductance values and fluoride concentrations. For these 22 wells, specific-conductance values ranged from 490 to $3,380 \mu \mathrm{S} / \mathrm{cm}$, and fluoride concentrations ranged from 0.3 to $14.0 \mathrm{mg} / \mathrm{L}$.

Water-quality data were available for one well within the monument. A list of these data is provided in appendix 2 of this report. 


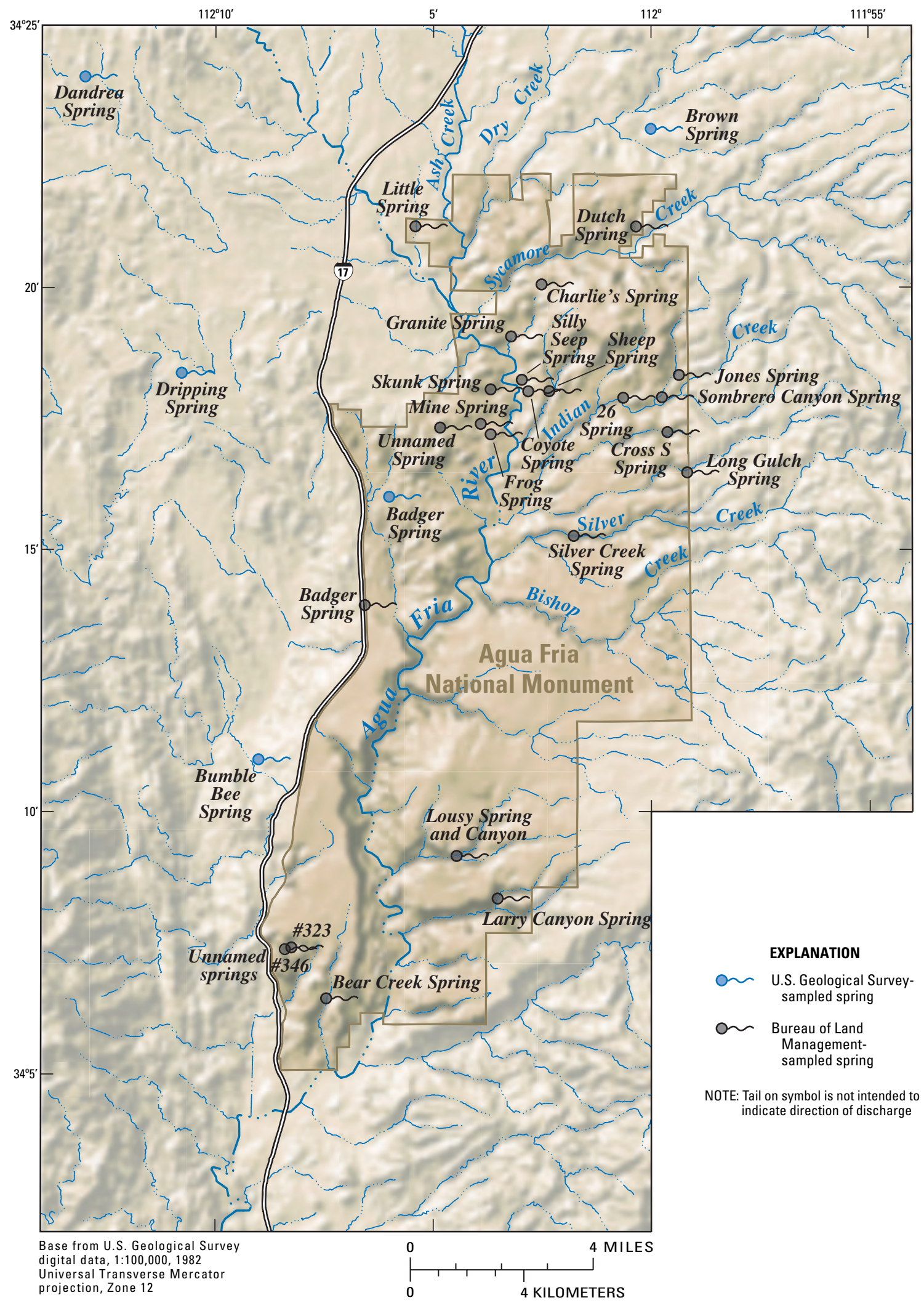

Figure 4. Locations of springs in the Agua Fria National Monument area, central Arizona. 


\section{Hydrologic Characteristics of the Agua Fria National Monument, Central Arizona, Reconnaissance Study}

Table 1. Springs in the Agua Fria National Monument study area, central Arizona

[Data from Bureau of Land Management and U.S. Geological Survey databases]

\begin{tabular}{|c|c|c|c|}
\hline Name & Latitude/longitude & Name & Latitude/longitude \\
\hline \multicolumn{4}{|c|}{ From Bureau of Land Management database } \\
\hline Dutch Spring & $34^{\circ} 21^{\prime} 08.4^{\prime \prime} / 112^{\circ} 00^{\prime} 19.9^{\prime}$ & Jones Spring & $34^{\circ} 18^{\prime} 19.2^{\prime \prime} / 111^{\circ} 59^{\prime} 21.5^{\prime \prime}$ \\
\hline Charlie's Spring & $34^{\circ} 20^{\prime} 02.3^{\prime \prime} / 112^{\circ} 02^{\prime} 30.0^{\prime \prime}$ & Sombrero Canyon Spring & $34^{\circ} 17^{\prime} 53.6^{\prime \prime} / 111^{\circ} 59^{\prime} 45.3^{\prime \prime}$ \\
\hline 26 Spring & $34^{\circ} 17^{\prime} 53.3^{\prime \prime} / 112^{\circ} 00^{\prime} 38.9^{\prime \prime}$ & Long Gulch Spring & $34^{\circ} 16^{\prime} 27.7^{\prime \prime} / 111^{\circ} 59^{\prime} 09.8^{\prime \prime}$ \\
\hline Sheep Spring & $34^{\circ} 18^{\prime} 00.7^{\prime \prime} / 112^{\circ} 02^{\prime} 20.0^{\prime \prime}$ & Badger Spring & $34^{\circ} 13^{\prime} 56.3^{\prime \prime} / 112^{\circ} 06^{\prime} 33.7^{\prime \prime}$ \\
\hline Coyote Spring & $34^{\circ} 18^{\prime} 00.3^{\prime \prime} / 112^{\circ} 02^{\prime} 48.3^{\prime \prime}$ & Lousy Spring and Canyon & $34^{\circ} 09^{\prime} 09.8^{\prime \prime} / 112^{\circ} 04^{\prime} 27.2^{\prime \prime}$ \\
\hline Mine Spring & $34^{\circ} 17^{\prime} 23.4^{\prime \prime} / 112^{\circ} 03^{\prime} 54.3^{\prime \prime}$ & Unnamed Spring \#346 & $34^{\circ} 07^{\prime} 23.2^{\prime \prime} / 112^{\circ} 08^{\prime} 23.2^{\prime \prime}$ \\
\hline Frog Spring & $34^{\circ} 17^{\prime} 11.5^{\prime \prime} / 112^{\circ} 03^{\prime} 40.9^{\prime \prime}$ & Bear Creek Spring & $34^{\circ} 06^{\prime} 27.3^{\prime \prime} / 112^{\circ} 07^{\prime} 26.9^{\prime \prime}$ \\
\hline \multicolumn{4}{|c|}{ From U.S. Geological Survey database } \\
\hline Brown Spring & $34^{\circ} 23^{\prime} 00^{\prime \prime} / 112^{\circ} 00^{\prime} 50^{\prime \prime}$ & Unnamed Spring & $34^{\circ} 23^{\prime} 25^{\prime \prime} / 112^{\circ} 13^{\prime} 45^{\prime \prime}$ \\
\hline Bumble Bee Spring & $34^{\circ} 11^{\prime} 35^{\prime \prime} / 112^{\circ} 09^{\prime} 25^{\prime \prime}$ & Badger Spring & $34^{\circ} 16^{\prime} 05^{\prime \prime} / 112^{\circ} 06^{\prime} 40^{\prime \prime}$ \\
\hline
\end{tabular}




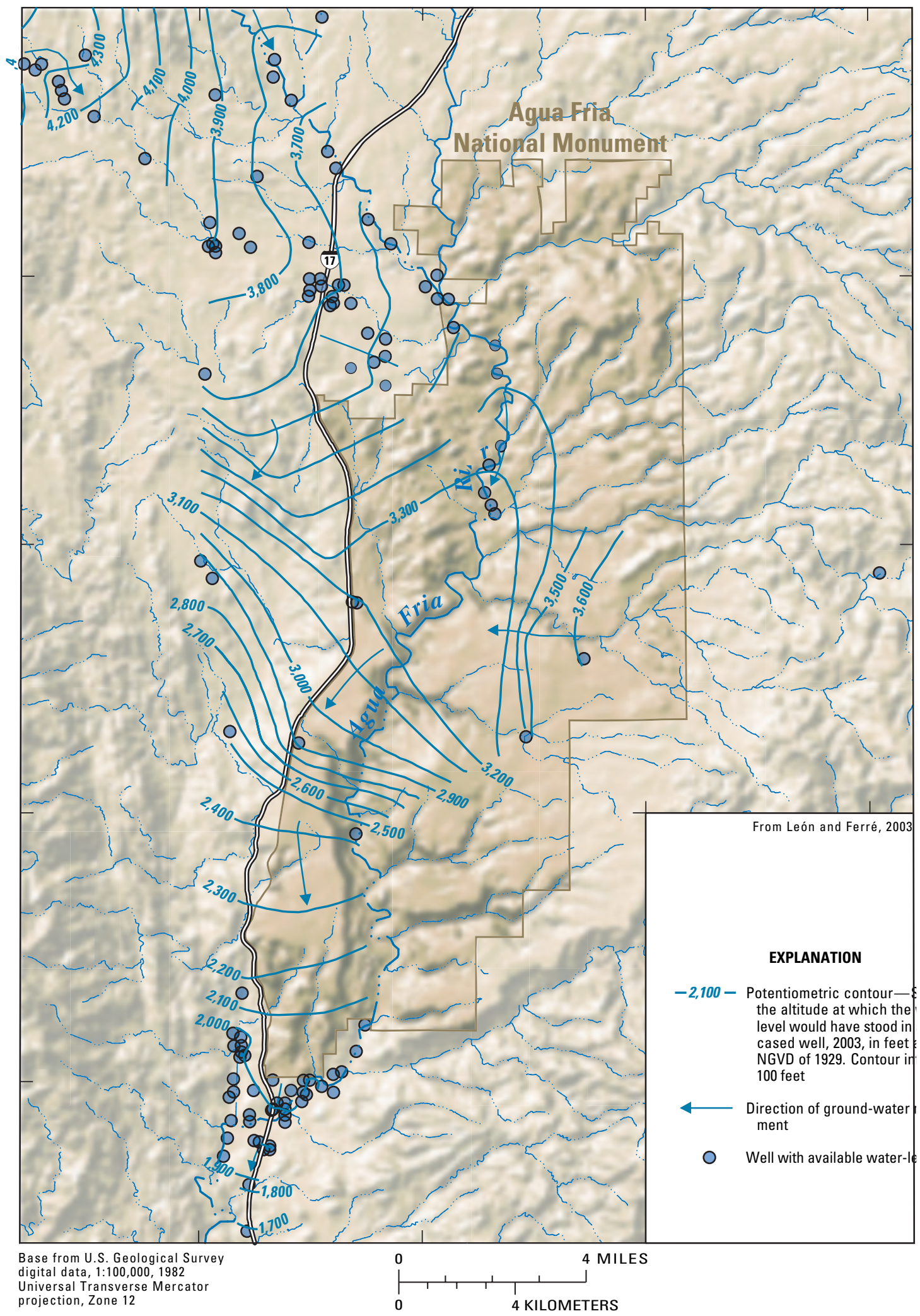

Figure 5. Potentiometric surface, 2003, Agua Fria National Monument area, central Arizona. 


\section{Hydrologic Characteristics of the Agua Fria National Monument, Central Arizona, Reconnaissance Study}

Table 2. Field-measured water properties and discharge data from the Bureau of Land Management for springs in the Agua Fria National Monument study area, central Arizona

$\left[\mu \mathrm{S} / \mathrm{cm}\right.$, microsiemens per centimeter; ${ }^{\circ} \mathrm{C}$, degrees Celsius; NTU, nephelometric turbidity units; $\mathrm{mg} / \mathrm{L}$, milligrams per liter; ppm, parts per million; GPM, gallons per minute; ---, not reported]

\begin{tabular}{|c|c|c|c|c|c|c|c|c|c|}
\hline Name & Sampling date(s) & $\begin{array}{c}\text { Specific } \\
\text { conductance } \\
(\mu \mathrm{S} / \mathrm{cm})\end{array}$ & pH & $\begin{array}{c}\text { Temperature } \\
\left({ }^{\circ} \mathrm{C}\right)\end{array}$ & $\begin{array}{l}\text { Turbidity } \\
\text { (NTU) }\end{array}$ & $\begin{array}{c}\text { Dissolved } \\
\text { oxygen } \\
\text { (mg/L) }\end{array}$ & $\begin{array}{c}\text { Dissolved } \\
\text { oxygen } \\
\text { (percent } \\
\text { saturation) }\end{array}$ & $\begin{array}{c}\text { Dissolved } \\
\text { solids } \\
\text { (ppm) }\end{array}$ & $\begin{array}{c}\text { Discharge } \\
\text { (GPM) }\end{array}$ \\
\hline Little Spring & 09/---/1985 & --- & --- & --- & --- & --- & --- & --- & 1 \\
\hline Charlie's Spring & 09/28/1993 & 470 & 7.5 & 19 & --- & --- & --- & --- & 3 \\
\hline Granite Spring & 09/29/1993 & 920 & 7.5 & 18 & --- & --- & --- & --- & .375 \\
\hline 26 Spring & 09/13/1993 & 540 & 7.9 & 27 & --- & --- & --- & --- & .375 \\
\hline Sheep Spring & 09/---/1993 & --- & --- & --- & --- & --- & --- & --- & 3.1 \\
\hline Coyote Spring & 09/16/1993 & 740 & 7.7 & 19 & --- & --- & --- & --- & 6 \\
\hline Silly Seep & 09/16/1993 & 470 & 7.8 & 18 & --- & --- & --- & --- & Seep \\
\hline Skunk Spring & 09/16/1993 & 710 & 7.7 & 25 & --- & --- & --- & --- & .375 \\
\hline Unnamed Spring & --- & --- & --- & --- & --- & --- & --- & --- & Seep \\
\hline Mine Spring & 09/02/1993 & 1,000 & 7.4 & 20 & --- & --- & --- & --- & .13 \\
\hline Frog Spring & 09/02/1993 & 1,280 & 7.3 & 28 & --- & --- & --- & --- & .4 \\
\hline Silver Creek Spring & 08/---/1993 & 540 & 7.6 & 23 & --- & --- & --- & --- & 1.8 \\
\hline Jones Spring & 09/13/1993 & 170 & 8.7 & 29 & --- & --- & --- & --- & Pool \\
\hline Sombrero Canyon Spring & 09/09/1993 & 550 & 7.2 & 21 & --- & --- & --- & --- & 4.5 \\
\hline Badger Spring & $04 / 09 / 1998$ & 1,270 & 7.8 & 15 & --- & --- & --- & & 1.8 \\
\hline Lousy Spring & $\begin{array}{l}09 / 24 / 1992- \\
10 / 24 / 1995\end{array}$ & ${ }^{1} 557$ & 18.0 & 22 & ${ }^{1} 0.88$ & ${ }^{17} 7.1$ & ${ }^{1} 89.9$ & ${ }^{1} 368$ & ${ }^{1} .24$ \\
\hline Larry Canyon Spring & --- & --- & --- & --- & --- & --- & --- & --- & 5.87 \\
\hline Dripping Spring & $\begin{array}{l}\text { 09/3/1992- } \\
05 / 21 / 1998\end{array}$ & ${ }^{1} 452$ & 17.8 & 19 & ${ }^{1} 1.3$ & ${ }^{1} 5.8$ & ${ }^{1} 70.7$ & $1_{301}$ & ${ }^{1} .01$ \\
\hline Bear Creek Spring & --- & --- & --- & --- & --- & --- & --- & --- & 1 \\
\hline
\end{tabular}

${ }^{1}$ Denotes average of measured values.

\section{Surface Water}

\section{Stream Descriptions and Monitoring}

Brown and others (1981) classified as perennial several reaches of the Agua Fria River and identified perennial reaches in tributaries of the Agua Fria River within and near the monument boundaries (Ash Creek, Little Ash Creek, Big Bug Creek, Little Sycamore Creek, Sycamore Creek, Indian Creek, and Silver Creek; fig. 6 and table 3). It is not known how the perennial reaches were delineated. More recent data by the Arizona Game and Fish Department (Valencia and others, 1993; Wahl and others, 1997) provided reclassification of several reaches of the Agua Fria River and its tributaries. GIS covers for these reclassified areas were not available during this study.

Within the monument, the Agua Fria River flows generally north to south, traversing almost the entire 23-mile length of the monument. The river is perennial in the northern part of the monument. Further downstream, however, streamflow is intermittent. Several tributary streams join the river within the monument; most of these drain the eastern part of the monument (fig. 6). 


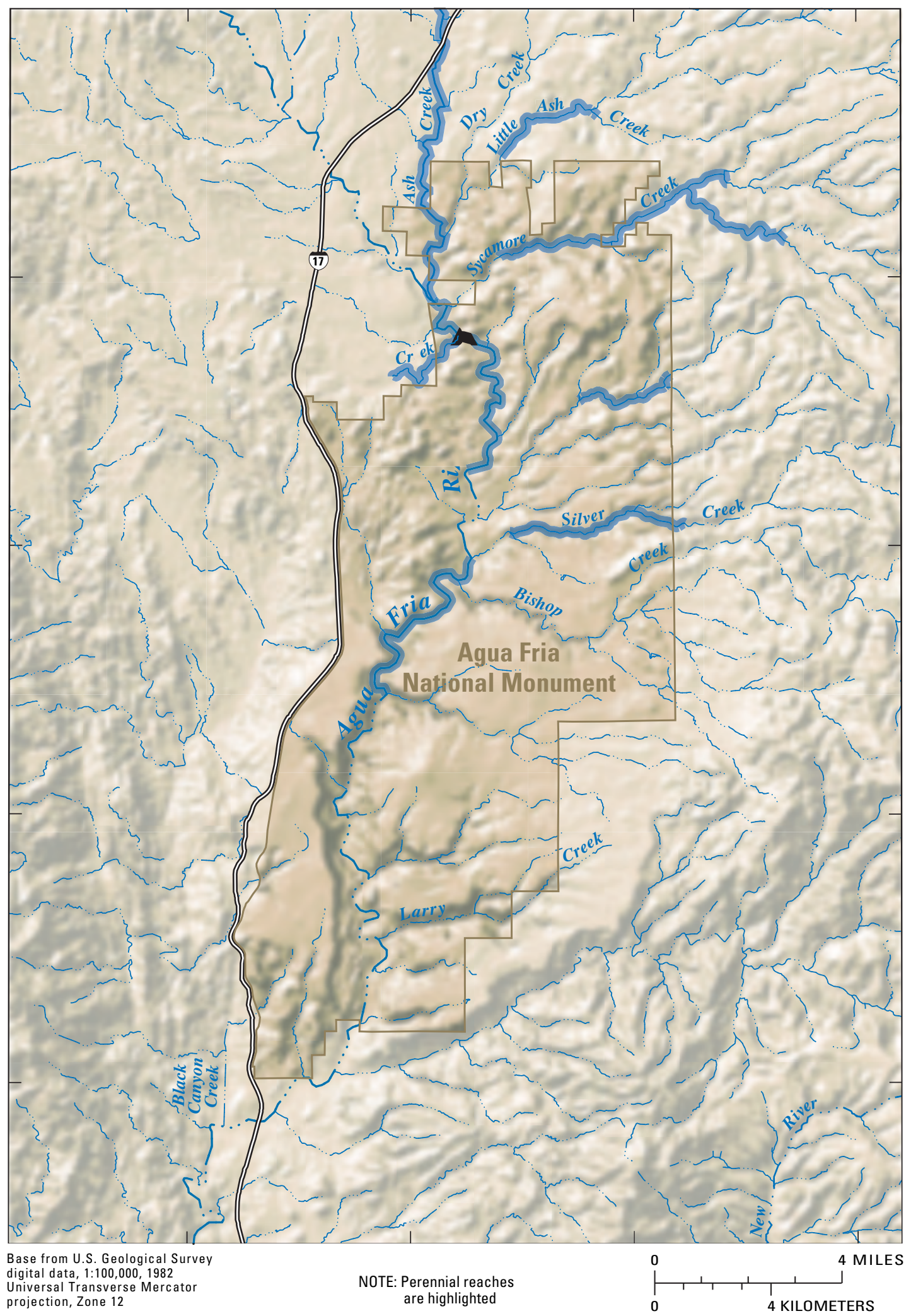

Figure 6. Agua Fria River and major tributaries in the Agua Fria National Monument study area, central Arizona. 


\section{Hydrologic Characteristics of the Agua Fria National Monument, Central Arizona, Reconnaissance Study}

Table 3. Lengths of perennial reaches of the Agua Fria River and tributaries of the Agua Fria River, Agua Fria National Monument study area, central Arizona

[Modified from Brown and others, 1981]

\begin{tabular}{lc}
\hline \multicolumn{1}{c}{ Name } & Length (miles) \\
\hline Agua Fria River & 6.2 \\
Ash Creek & 8.1 \\
Little Ash Creek & 2.9 \\
Little Sycamore Creek & 1.1 \\
Sycamore Creek & 7.9 \\
Big Bug Creek & 2.4 \\
Indian Creek & 2.4 \\
Silver Creek & 4.2 \\
\hline
\end{tabular}

Streamflow in the Agua Fria River near the monument is monitored by the USGS at two streamflowgaging stations (fig. 6 and table 4). One station is within the monument near the northern boundary and the other is about $8.3 \mathrm{mi}$ downstream from the southern boundary (not shown on figures). The upstream station (Agua Fria River near Mayer, Arizona, 09512500) is at the Sycamore damsite about $0.18 \mathrm{mi}$ downstream from the mouth of Big Bug Creek and has been in operation since 1940.

Table 4. U.S. Geological Survey streamflow-gaging stations on the Agua Fria River in the Agua Fria National Monument study area, central Arizona

\begin{tabular}{cccc}
\hline Station name & $\begin{array}{c}\text { Station } \\
\text { number }\end{array}$ & $\begin{array}{c}\text { Drainage area } \\
\text { (square miles) }\end{array}$ & $\begin{array}{c}\text { Period of } \\
\text { record }\end{array}$ \\
\hline $\begin{array}{c}\text { Agua Fria River near } \\
\text { Mayer, Arizona }\end{array}$ & 09512500 & 585 & $1940-2004$ \\
$\begin{array}{c}\text { Agua Fria River near } \\
\text { Rock Springs, Arizona }\end{array}$ & 09512800 & 1,111 & $1970-2004$ \\
\hline
\end{tabular}

Streamflow measured at Agua Fria near Mayer represents drainage from an area of $585 \mathrm{mi}^{2}$ that includes flow from tributaries Ash, Little Ash, Dry, Sycamore, and Big Bug Creeks. The downstream station (Agua Fria River near Rock Springs, Arizona, 09512800) is $2.5 \mathrm{mi}$ southwest of Rock Springs, Arizona, and has been in operation since January 1970. Streamflow measured at this site represents base flow and runoff from a drainage area of $1,111 \mathrm{mi}^{2}$ that includes outflow from tributaries Indian Creek, Silver Creek, Bishop Creek, Antelope Creek, Badger Spring Wash, Lousy Canyon, Larry Creek, and Black Canyon Creek. Data for these two stations are available online at http://waterdata.usgs.gov/ az/nwis/.
Additional surface-water data were obtained from USGS NWIS database records, from BLM surface-water monitoring records, and from data collected by USGS staff during a seepage study conducted in May 2002.

The USGS NWIS database contained records for six sites on the Agua Fria River within and near the monument boundaries for which either water-quality or streamflow data were available (fig. 7 and table 5). The two sites outside the monument are Agua Fria River above Arcosanti and Agua Fria River above Sycamore Creek. The four sites within the monument are Agua Fria River below Sycamore Creek; Agua Fria River near Mayer, Arizona; Agua Fria River near Bloody Basin Road; and Agua Fria River below Bloody Basin Road at Horseshoe Ranch.

Streamflow and field properties were measured at main-stem and tributary sites by BLM staff between June 1992 and November 1998 (fig. 7 and table 6). Measurements were made at 16 sites within and near the boundaries of the monument including 3 sites along the Agua Fria River and 13 sites along tributaries within and near the monument. Field properties included specific conductance, dissolved solids, $\mathrm{pH}$, dissolved oxygen, and turbidity.

In May 2002, a seepage study was conducted to measure streamflow, specific conductance, and temperature along the Agua Fria River at 14 sites within and near the monument (fig. 7 and table 7). During this study, almost the entire length of the river within the monument was traversed. Measurements were made using standard USGS procedures (Rantz and others, 1982; Wilde and Radtke, 1998).

\section{Streamflow Characteristics}

Streamflow in the Agua Fria River within the monument varies by season. Snowmelt runoff and rainfall contribute to high streamflows during the winter and early spring, respectively. Streamflow is also high in late summer as a result of runoff from monsoonal storms. Streamflow is low in May, June, October, and November (figs. 8, 9, 10, and 11) when precipitation typically is significantly less than at other times of the year.

Winter rains (those during November-March) have a significant effect on streamflow (figs. 8 and 10). Although the mean monthly rainfall is higher during the summer monsoon season, diminished evapotranspiration demands and elevated antecedent soil-moisture conditions during the winter provide greater opportunity for runoff. Additionally, winter storms tend to cover large areas. 


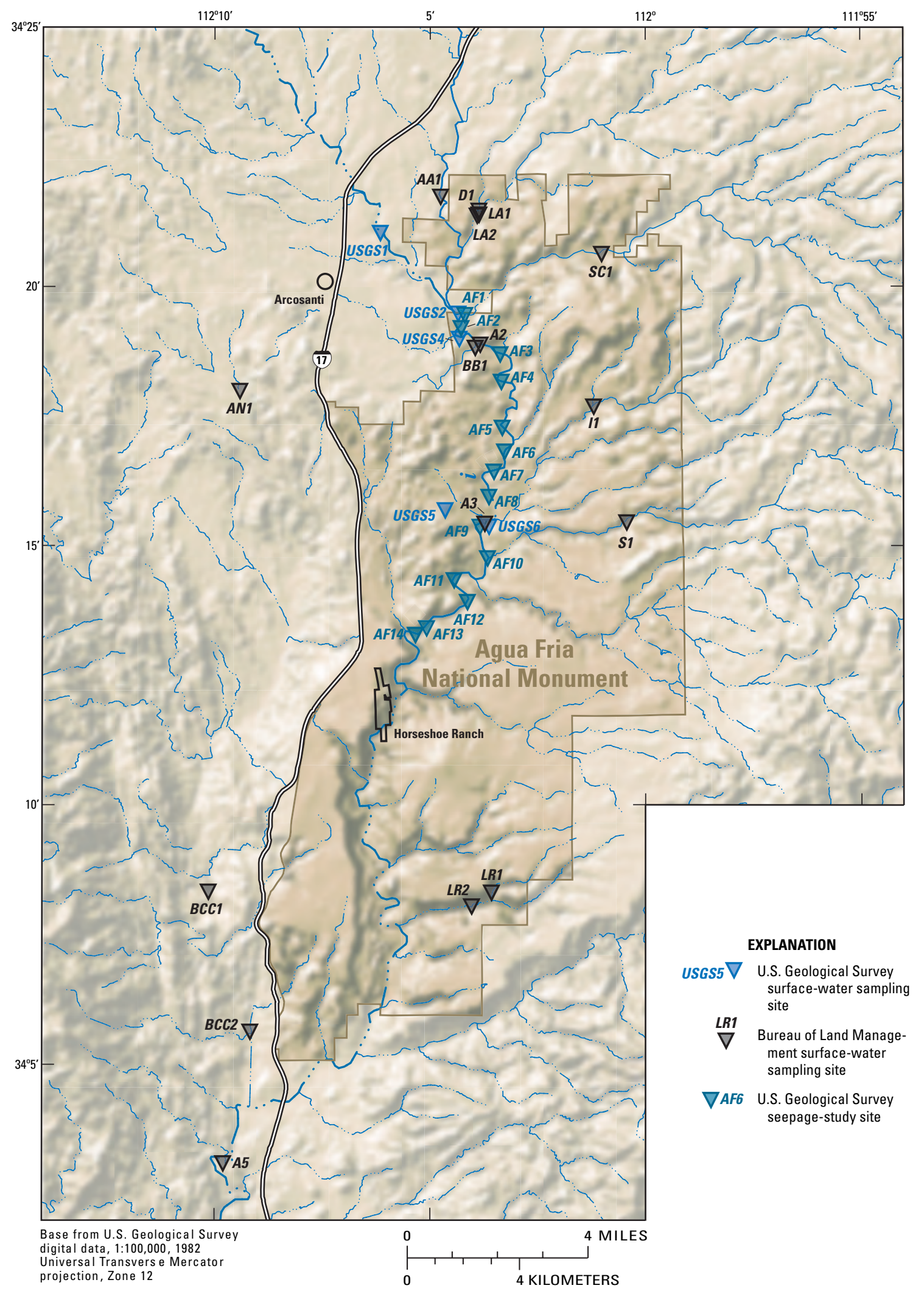

Figure 7. Surface-water sites in the Agua Fria National Monument study area, central Arizona, at which data were collected by the U.S. Geological Survey or the Bureau of Land Management, 1980-2002. 


\section{Hydrologic Characteristics of the Agua Fria National Monument, Central Arizona, Reconnaissance Study}

Table 5. Surface-water sites on the Agua Fria River in the Agua Fria National Monument study area, central Arizona, for which records were available in the U.S. Geological Survey National Water Information System, 2003

\begin{tabular}{lcccc}
\hline \multicolumn{1}{c}{ Site name } & Site identifier & Latitude/longitude & $\begin{array}{c}\text { Number of } \\
\text { records }\end{array}$ & Date of record(s) \\
\hline Agua Fria River above Arcosanti & USGS1 & $34^{\circ} 21^{\prime} 05^{\prime \prime} / 112^{\circ} 06^{\prime} 08^{\prime \prime}$ & 1 & $11 / 23 / 1980$ \\
Agua Fria River above Sycamore Creek & USGS2 & $34^{\circ} 19^{\prime} 29^{\prime \prime} / 112^{\circ} 04^{\prime} 10^{\prime \prime}$ & 2 & $11 / 24 / 1980,06 / 04 / 1981$ \\
Agua Fria River below Sycamore Creek & USGS3 & $34^{\circ} 19^{\prime} 25^{\prime \prime} / 112^{\circ} 04^{\prime} 17^{\prime \prime}$ & 2 & $11 / 24 / 1980,06 / 04 / 1981$ \\
Agua Fria River near Mayer, Arizona & USGS4 & $34^{\circ} 18^{\prime} 55^{\prime \prime} / 112^{\circ} 03^{\prime} 48^{\prime \prime}$ & 2 & $11 / 25 / 1980,05 / 22 / 1996$ \\
& $(09512500)$ & & & \\
Agua Fria River near Bloody Basin Road & USGS5 & $34^{\circ} 15^{\prime} 43^{\prime \prime} / 112^{\circ} 04^{\prime} 39^{\prime \prime}$ & 1 & $05 / 21 / 1996$ \\
$\begin{array}{c}\text { Agua Fria River below Bloody Basin Road } \\
\text { at Horseshoe Ranch }\end{array}$ & USGS6 & $34^{\circ} 15^{\prime} 28^{\prime \prime} / 112^{\circ} 03^{\prime} 46^{\prime \prime}$ & 1 & $12 / 12 / 1980$ \\
\hline
\end{tabular}

Table 6. Surface-water sites in the Agua Fria National Monument study area, central Arizona, at which streamflow and field properties were measured by Bureau of Land Management staff, June 1992 to November 1998

\begin{tabular}{lcccc}
\hline \multicolumn{1}{c}{ Location } & Site identifier & Latitude/longitude & Number of records & Period of records \\
\hline Dry Creek & D1 & $34^{\circ} 21^{\prime} 29^{\prime \prime} / 112^{\circ} 03^{\prime} 52^{\prime \prime}$ & 13 & $10 / 06 / 1992$ to $11 / 04 / 1998$ \\
Ash Creek & AA1 & $34^{\circ} 21^{\prime} 47^{\prime \prime} / 112^{\circ} 04^{\prime} 47^{\prime \prime}$ & 21 & $09 / 05 / 1992$ to $10 / 03 / 1995$ \\
Little Ash Creek & LA1 & $34^{\circ} 21^{\prime} 26^{\prime \prime} / 112^{\circ} 03^{\prime} 50^{\prime \prime}$ & 12 & $10 / 05 / 1992$ to $10 / 03 / 1995$ \\
Little Ash Creek & LA2 & $34^{\circ} 21^{\prime} 26^{\prime \prime} / 112^{\circ} 03^{\prime} 55^{\prime \prime}$ & 13 & $10 / 05 / 1992$ to $11 / 04 / 1998$ \\
Sycamore Creek & SC1 & $34^{\circ} 20^{\prime} 41^{\prime \prime} / 112^{\circ} 01^{\prime} 00^{\prime \prime}$ & 8 & $08 / 19 / 1992$ to $10 / 25 / 1995$ \\
Agua Fria River & A2 & $34^{\circ} 18^{\prime} 59^{\prime \prime} / 112^{\circ} 03^{\prime} 59^{\prime \prime}$ & 27 & $09 / 25 / 1992$ to $10 / 04 / 1995$ \\
Big Bug Creek & BB1 & $34^{\circ} 18^{\prime} 52^{\prime \prime} / 112^{\circ} 03^{\prime} 57^{\prime \prime}$ & 27 & $06 / 25 / 1992$ to $11 / 04 / 1998$ \\
Antelope Creek & AN1 & $34^{\circ} 18^{\prime} 00^{\prime \prime} / 112^{\circ} 09^{\prime} 27^{\prime \prime}$ & 8 & $09 / 30 / 1994$ to $04 / 14 / 1998$ \\
Indian Creek & I1 & $34^{\circ} 17^{\prime} 43^{\prime \prime} / 112^{\circ} 01^{\prime} 111^{\prime \prime}$ & 9 & $09 / 14 / 1992$ to $10 / 27 / 1994$ \\
Agua Fria River & A3 & $34^{\circ} 15^{\prime} 28^{\prime \prime} / 112^{\circ} 03^{\prime} 44 "$ & 20 & $06 / 25 / 1992$ to $10 / 09 / 1998$ \\
Silver Creek & S1 & $34^{\circ} 15^{\prime} 29^{\prime \prime} / 112^{\circ} 00^{\prime} 52^{\prime \prime}$ & 12 & $10 / 05 / 1992$ to $11 / 13 / 1998$ \\
Larry Creek Tributary & LR1 & $34^{\circ} 08^{\prime} 21^{\prime \prime} / 112^{\circ} 03^{\prime} 31^{\prime \prime}$ & 9 & $12 / 17 / 1992$ to $06 / 22 / 1995$ \\
Larry Creek & LR2 & $34^{\circ} 08^{\prime} 05^{\prime \prime} / 112^{\circ} 04^{\prime} 01^{\prime \prime}$ & 1 & $12 / 17 / 1992$ \\
Agua Fria River & A5 & $34^{\circ} 03^{\prime} 09^{\prime \prime} / 112^{\circ} 09^{\prime} 47^{\prime \prime}$ & 49 & $03 / 01 / 1992$ to $10 / 08 / 1998$ \\
Black Canyon Creek & BCC1 & $34^{\circ} 08^{\prime} 23^{\prime \prime} / 112^{\circ} 10^{\prime} 10^{\prime \prime}$ & 29 & $03 / 19 / 1993$ to $10 / 20 / 1998$ \\
Black Canyon Creek & BCC2 & $34^{\circ} 05^{\prime} 41^{\prime \prime} / 112^{\circ} 09^{\prime} 10^{\prime \prime}$ & 17 & $03 / 13 / 1992$ to $02 / 03 / 1993$ \\
\hline
\end{tabular}

Table 7. Surface-water sites on the Agua Fria River in the Agua Fria National Monument, central Arizona, at which streamflow, specific conductance, and temperature were measured during the seepage study in May 2002

\begin{tabular}{ccc}
\hline Site name & Latitude/longitude & Date \\
\hline AF1 & $34^{\circ} 19^{\prime} 30^{\prime \prime} / 112^{\circ} 04^{\prime} 20^{\prime \prime}$ & $05 / 20 / 2002$ \\
AF2 & $34^{\circ} 19^{\prime} 02^{\prime \prime} / 112^{\circ} 04^{\prime} 18^{\prime \prime}$ & $05 / 20 / 2002$ \\
AF3 & $34^{\circ} 18^{\prime} 42^{\prime \prime} / 112^{\circ} 03^{\prime} 22^{\prime \prime}$ & $05 / 20 / 2002$ \\
AF4 & $34^{\circ} 18^{\prime} 10^{\prime \prime} / 112^{\circ} 03^{\prime} 19^{\prime \prime}$ & $05 / 21 / 2002$ \\
AF5 & $34^{\circ} 17^{\prime} 17^{\prime \prime} / 112^{\circ} 03^{\prime} 20^{\prime \prime}$ & $05 / 21 / 2002$ \\
AF6 & $34^{\circ} 16^{\prime} 50^{\prime \prime} / 112^{\circ} 03^{\prime} 15^{\prime \prime}$ & $05 / 20 / 2002$ \\
AF7 & $34^{\circ} 16^{\prime} 28^{\prime \prime} / 112^{\circ} 03^{\prime} 30^{\prime \prime}$ & $05 / 20 / 2002$ \\
AF8 & $34^{\circ} 15^{\prime} 58^{\prime \prime} / 112^{\circ} 03^{\prime} 36^{\prime \prime}$ & $05 / 20 / 2002$ \\
AF9 & $34^{\circ} 15^{\prime} 28^{\prime \prime} / 112^{\circ} 03^{\prime} 41^{\prime \prime}$ & $05 / 20 / 2002$ \\
AF10 & $34^{\circ} 14^{\prime} 48^{\prime \prime} / 112^{\circ} 03^{\prime} 41^{\prime \prime}$ & $05 / 21 / 2002$ \\
AF11 & $34^{\circ} 14^{\prime} 24^{\prime \prime} / 112^{\circ} 04^{\prime} 27^{\prime \prime}$ & $05 / 21 / 2002$ \\
AF12 & $34^{\circ} 13^{\prime} 58^{\prime \prime} / 112^{\circ} 04^{\prime} 06^{\prime \prime}$ & $05 / 22 / 2002$ \\
AF13 & $34^{\circ} 13^{\prime} 28^{\prime \prime} / 112^{\circ} 05^{\prime} 05^{\prime \prime}$ & $05 / 22 / 2002$ \\
AF14 & $34^{\circ} 13^{\prime} 18^{\prime \prime} / 112^{\circ} 05^{\prime} 20^{\prime \prime}$ & $05 / 22 / 2002$ \\
\hline
\end{tabular}




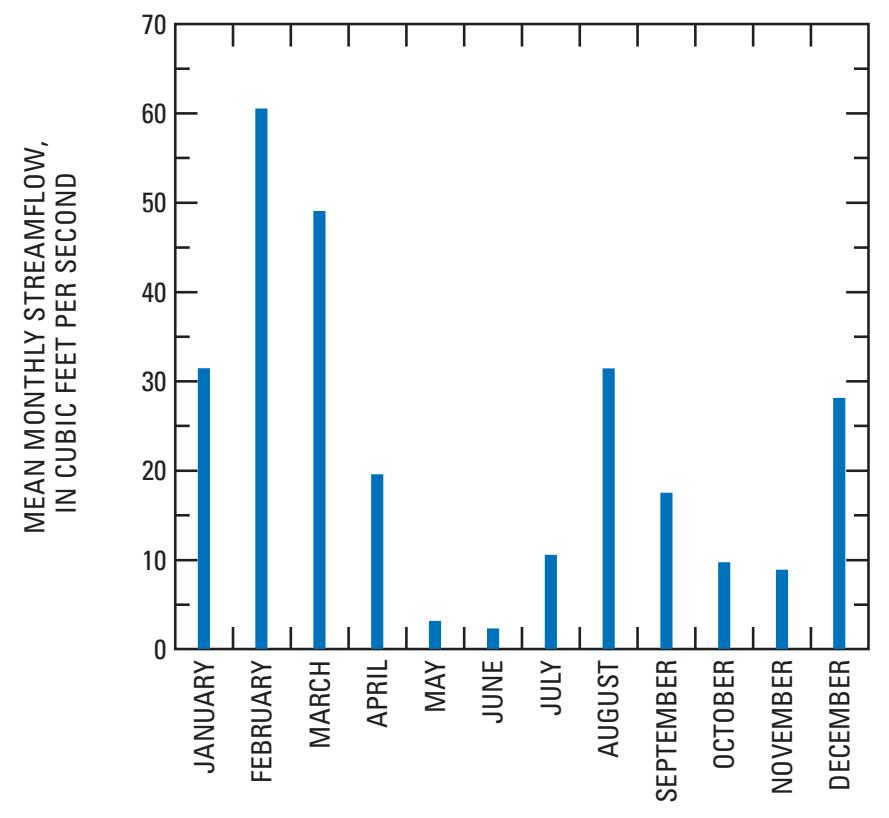

Figure 8. Mean monthly streamflow at Agua Fria River near Mayer, Arizona, 1940-2002.

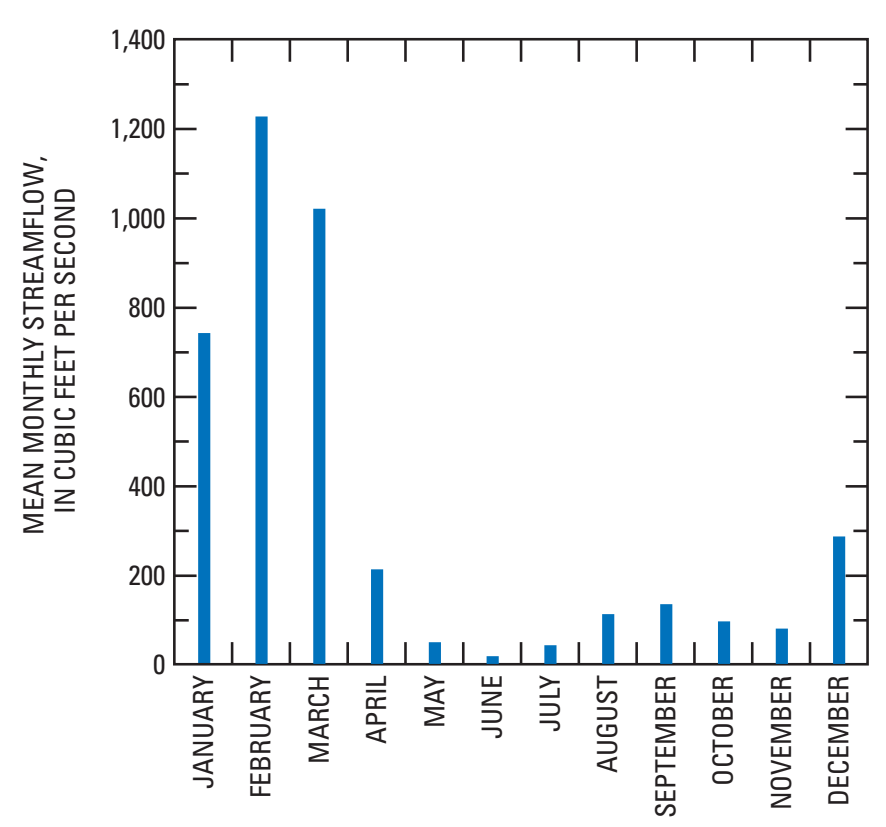

Figure 10. Mean monthly streamflow at Agua Fria River near Rock Springs, Arizona, 1970-2002.

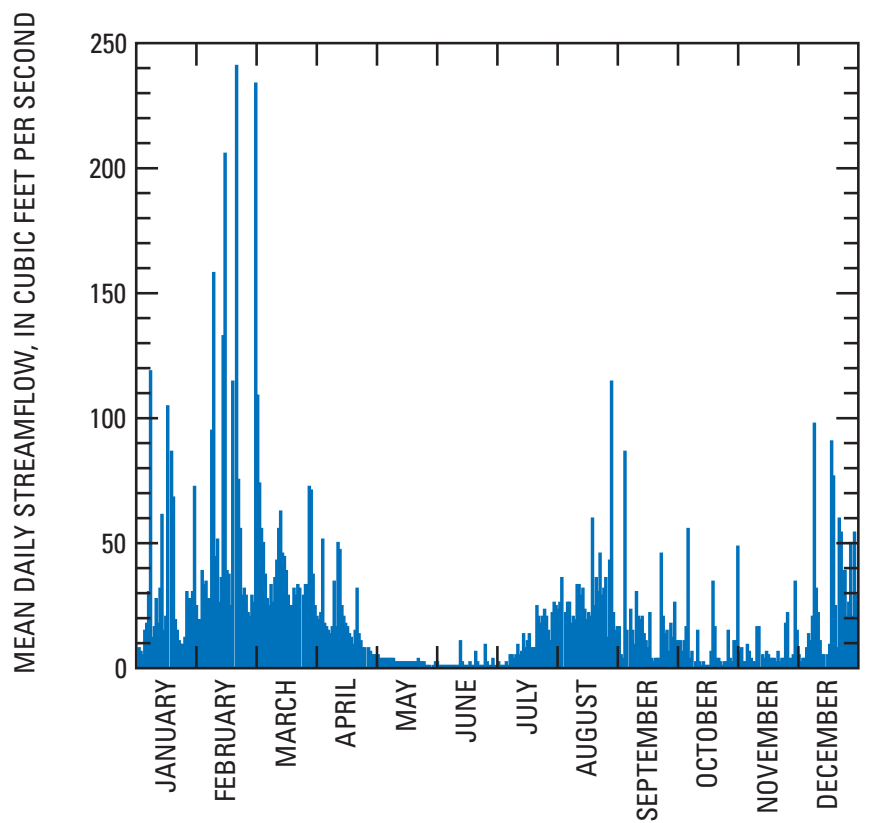

Figure 9. Mean daily streamflow at Agua Fria River near Mayer, Arizona, 1940-2002.

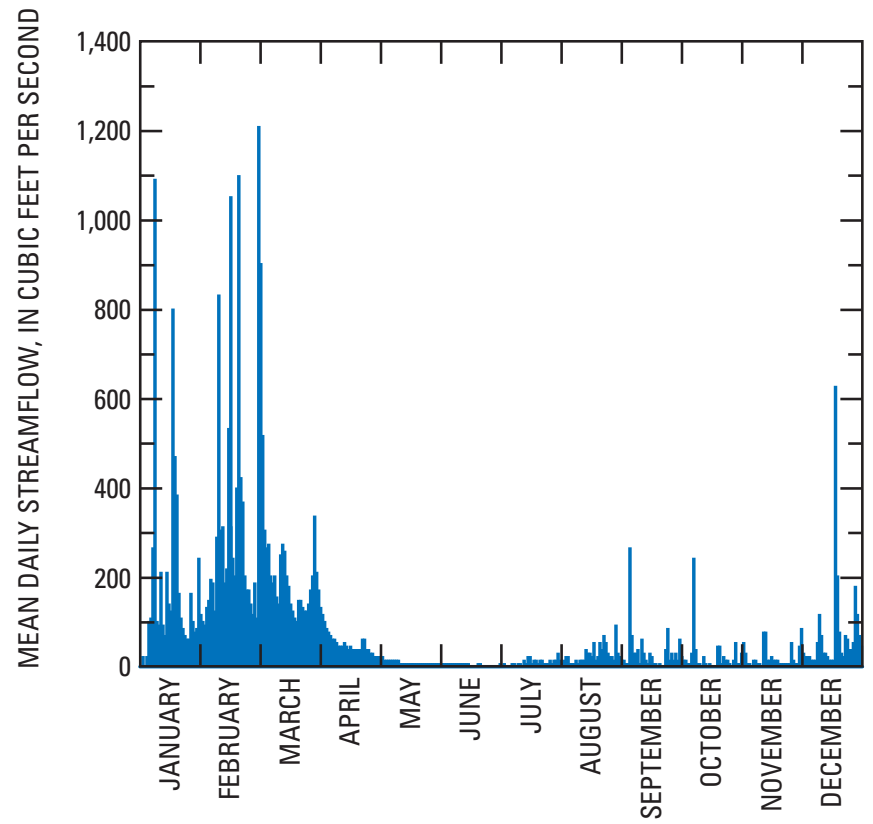

Figure 11. Mean daily streamflow at Agua Fria River near Rock Springs, Arizona, 1970-2002. 


\section{Hydrologic Characteristics of the Agua Fria National Monument, Central Arizona, Reconnaissance Study}

Monsoonal storms during the summer tend to develop rapidly and can be intense, but generally are localized and short lived. Consequently, runoff from these storms can be significant and cause rapid increases in streamflow. This is particularly true in areas where the alluvium is thin and depth to bedrock is shallow. There are several reaches of the Agua Fria River where the river canyon is narrow and deeply incised and the alluvium is thin or absent.

Records were obtained for four precipitation gages near the monument (table 8 and figs. 1 and 12). Records for two of these gages, Cordes and Crown King, were obtained from the Western Regional Climate Center Desert Research Institute (2004).

Table 8. Precipitation gages in the Agua Fria National Monument study area, central Arizona

[Altitude data from Barnett and others, 2003]

\begin{tabular}{lccc}
\hline \multicolumn{1}{c}{$\begin{array}{c}\text { Station name } \\
\text { (number) }\end{array}$} & $\begin{array}{c}\text { Altitude } \\
\text { (feet) }\end{array}$ & $\begin{array}{c}\text { Period } \\
\text { of record }\end{array}$ & $\begin{array}{c}\text { Mean annual } \\
\text { precipitation } \\
\text { (inches) }\end{array}$ \\
\hline Cordes (022109) & 3,770 & $1948-2003$ & 15.03 \\
Crown King (022329) & $1,25,920-6,000$ & $1914-1995$ & 28.47 \\
Bumble Bee & 2,500 & $1954-1979$ & 15.79 \\
Dugas 2SE & $1,24,000-4,040$ & $1920-1972$ & 17.23 \\
\hline
\end{tabular}

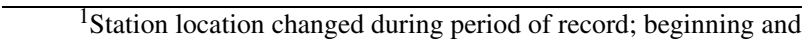
ending altitudes given.

${ }^{2}$ Station location outside of study area.
Records for the other two gages, Bumble Bee and Dugas 2SE, were obtained from the University of Arizona Institute of Atmospheric Physics (2004). Although none of these gages are within the monument, data from the Cordes, Bumble Bee, and Dugas 2SE gages likely are representative of precipitation within the monument owing to their locations and altitudes. Precipitation measured at the Crown King gage likely is greater than what would be measured within the monument because the gage is at a higher altitude than the monument.

Daily, monthly, and annual streamflow data, and streamflow statistics for Agua Fria River near Mayer and Agua Fria River near Rock Springs have been summarized in the annual Water Data Report for Arizona (such as Smith and others, 1997). Pope and others (1998) computed statistical summaries of streamflow at USGS stations in Arizona, including the two Agua Fria River stations. Data presented in this section are derived primarily from Pope and others (1998).

The highest measured streamflow at Agua Fria River near Mayer between 1940 and 2002 was 33,100 $\mathrm{ft}^{3} / \mathrm{s}$ on February 19, 1980 (fig. 13). This flow has a recurrence interval of between 50 and 100 years. The maximum annual mean flow was $143 \mathrm{ft}^{3} / \mathrm{s}$ (1993) and the minimum was $1.35 \mathrm{ft}^{3} / \mathrm{s}$ (1962; fig. 14).

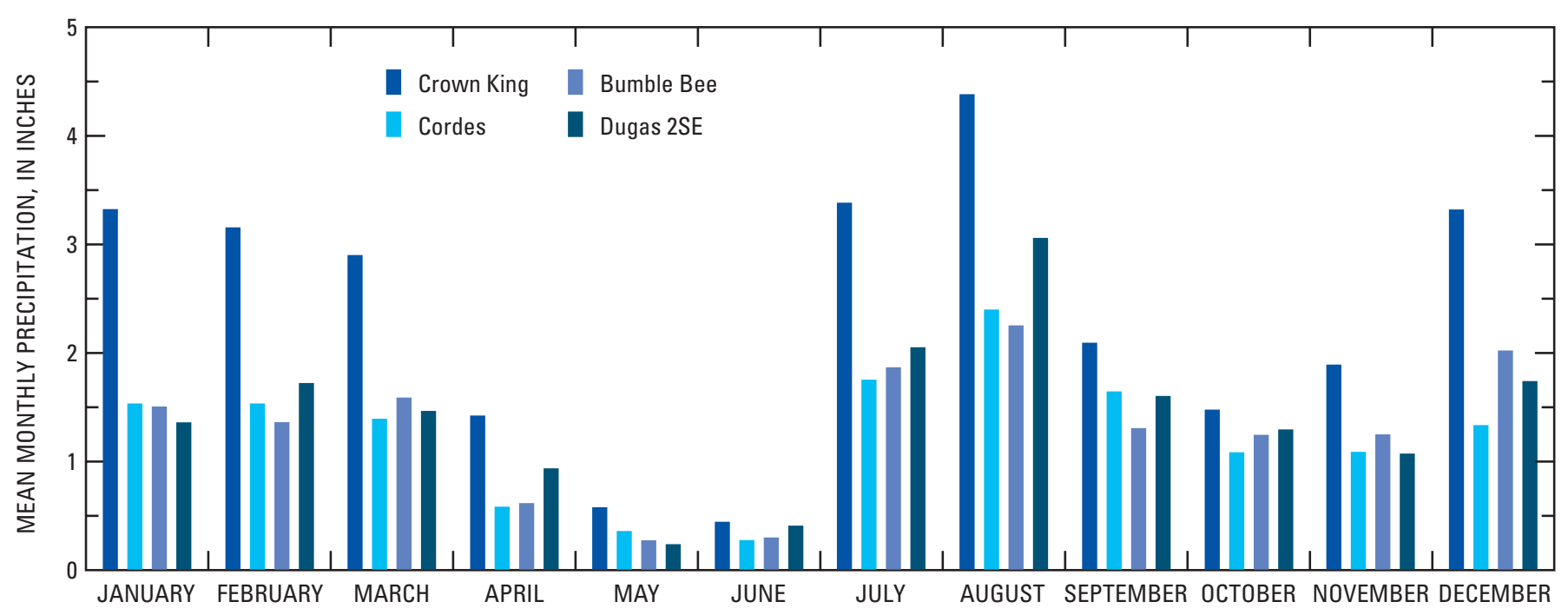

Figure 12. Mean monthly precipitation at gages near the Agua Fria National Monument area, central Arizona. 


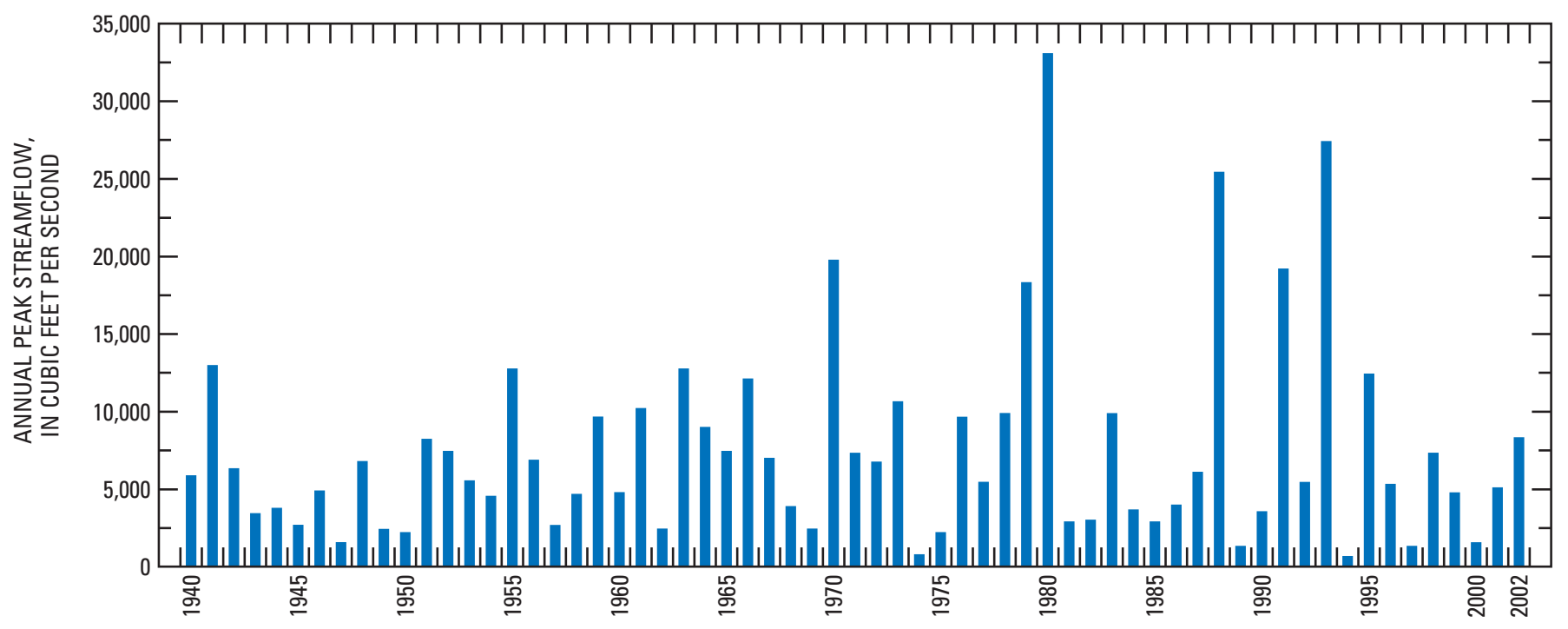

Figure 13. Annual peak streamflow at Agua Fria River near Mayer, Arizona, 1940-2002.

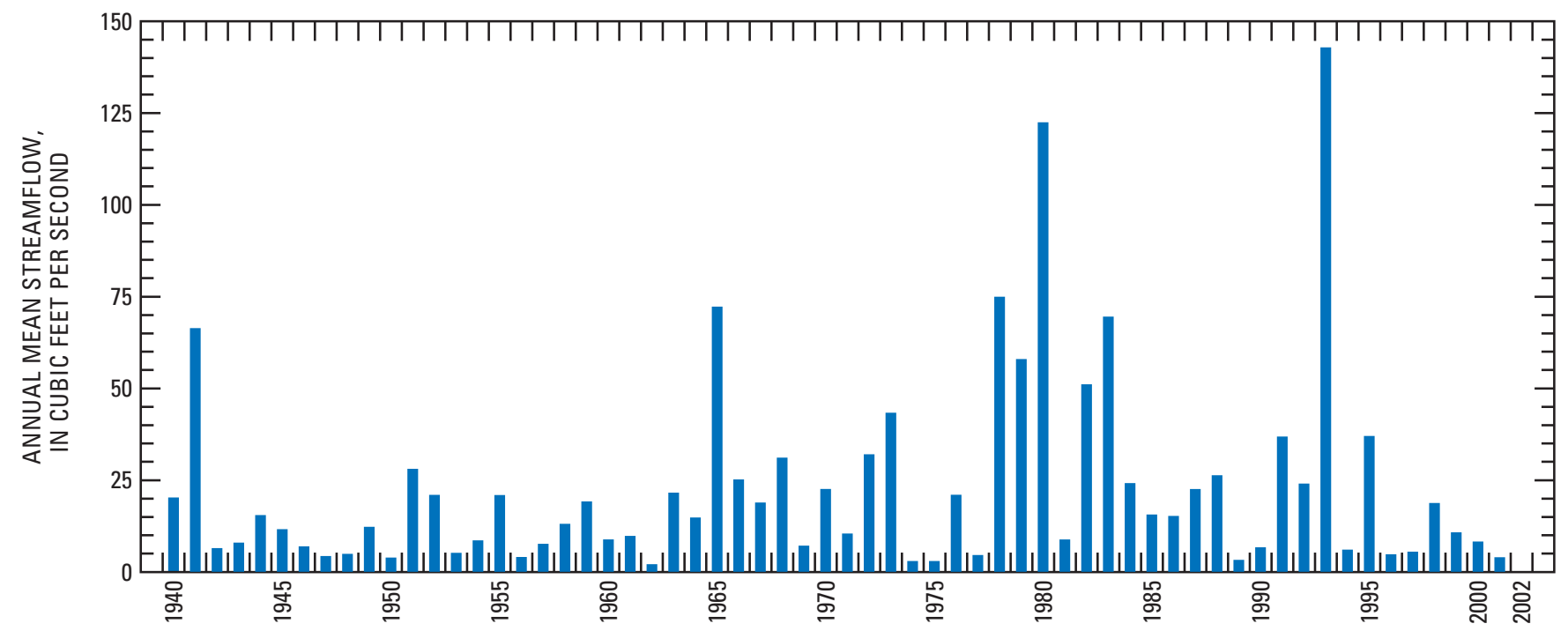

Figure 14. Annual mean streamflow at Agua Fria River near Mayer, Arizona, 1940-2001.

Between 1970 and 2002, the highest streamflow recorded at Agua Fria River near Rock Springs was $59,500 \mathrm{ft}^{3} / \mathrm{s}$ on February 19, 1980 (fig. 15). A peak flow of $85,000 \mathrm{ft}^{3} / \mathrm{s}$ was measured in 1920 before systematic recording began. These peak flows have recurrence intervals of between 10 and 25 years. The maximum annual mean flow at this site was $498 \mathrm{ft}^{3} / \mathrm{s}$
(1993), and the minimum was $2.11 \mathrm{ft}^{3} / \mathrm{s}$ (1975; fig. 16). Because streamflow measured at the Rock Springs station is derived from a larger drainage area, high flows measured at Agua Fria River near Rock Springs are higher than those measured at Agua Fria River near Mayer and are likely higher than those within the monument. 


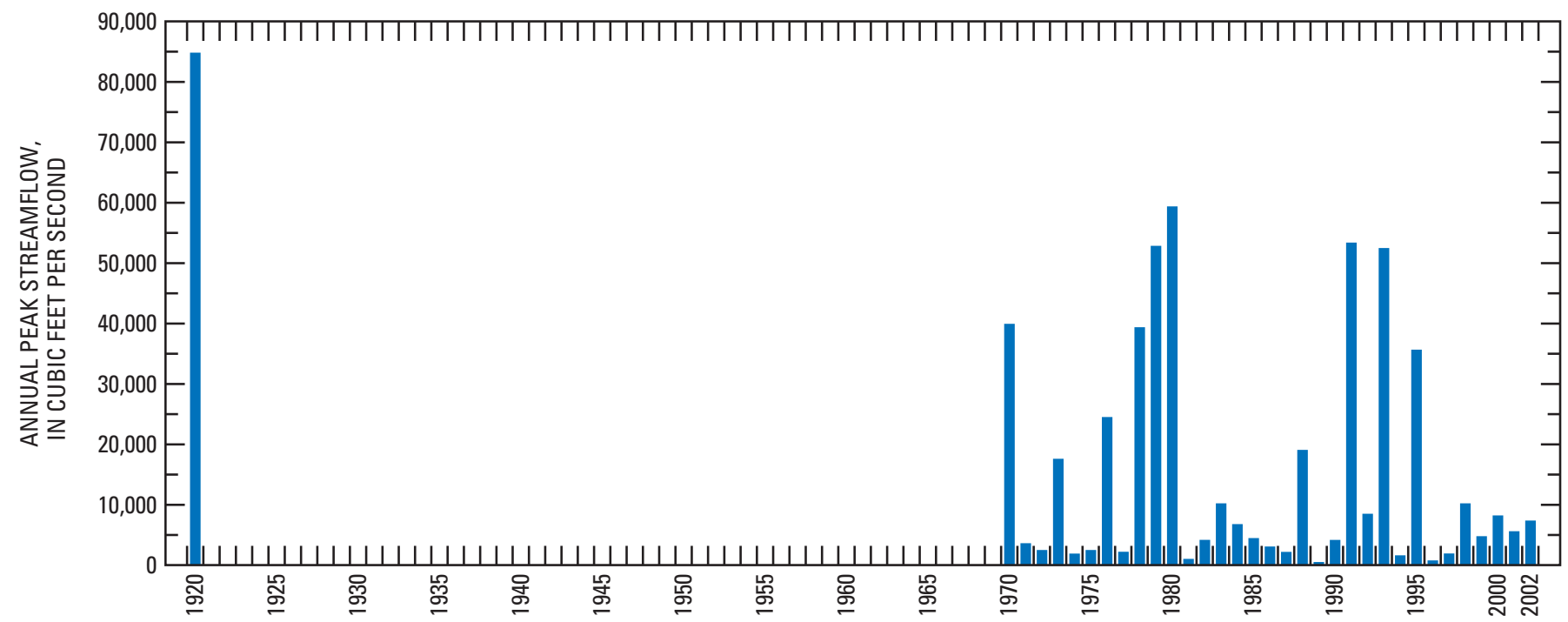

Figure 15. Annual peak streamflow at Agua Fria River near Rock Springs, Arizona, 1920-2002.

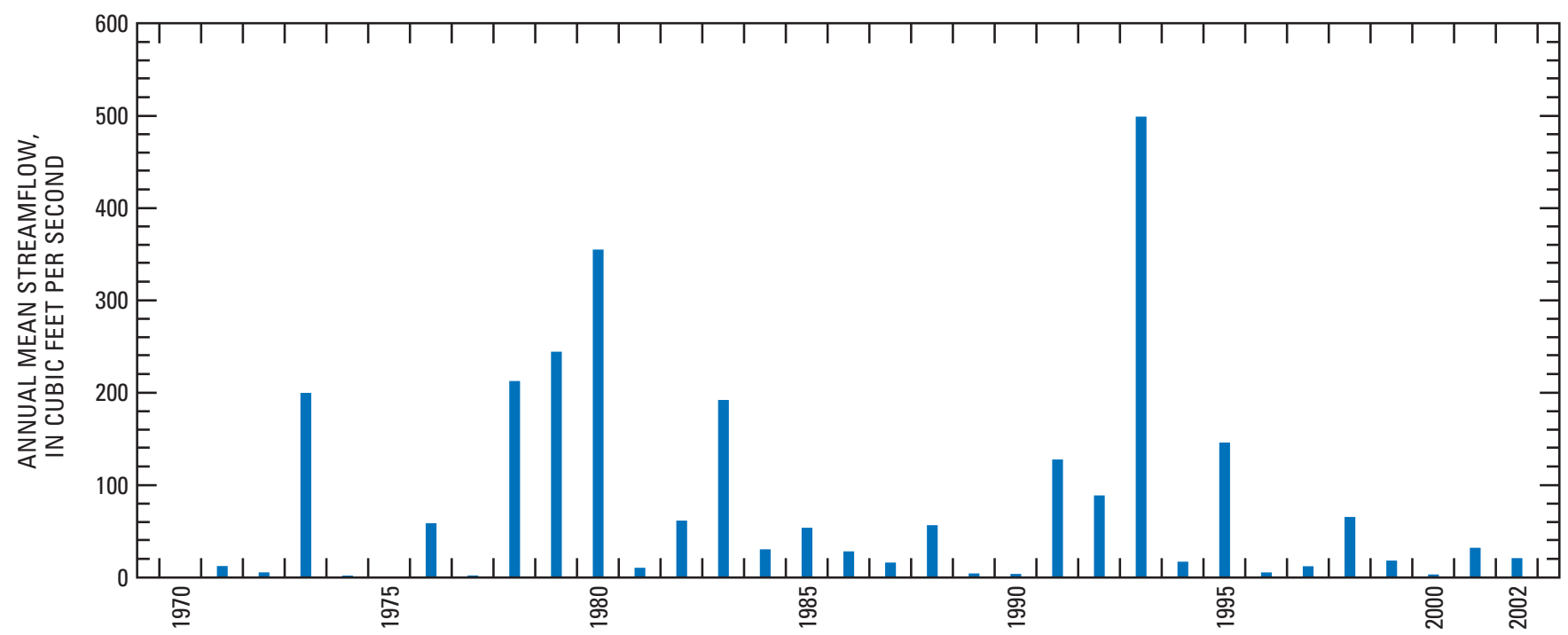

Figure 16. Annual mean streamflow at Agua Fria River near Rock Springs, Arizona, 1971-2001. 
The maximum and minimum mean monthly streamflows at Agua Fria River near Mayer occur in February $\left(60.4 \mathrm{ft}^{3} / \mathrm{s}\right)$ and June $\left(2.57 \mathrm{ft}^{3} / \mathrm{s}\right)$, respectively (fig. 8). The maximum and minimum mean daily flows occur on February $20\left(242 \mathrm{ft}^{3} / \mathrm{s}\right)$ and July $4\left(1.03 \mathrm{ft}^{3} / \mathrm{s}\right)$, respectively (fig. 9). Daily mean flow-duration data for this site indicate that for 50 percent of the time, flow equaled or exceeded $2.2 \mathrm{ft}^{3} / \mathrm{s}$ (table 9). Prior to 1978 , low and negligible flows at this streamflow-gaging station were affected by diversions to a canal. This canal has been inoperative since 1977, and water is no longer being diverted.

Table 9. Duration of mean daily flow, Agua Fria River near Mayer, Arizona, 1941-96

[Data from Pope and others, 1998. Streamflow, in cubic feet per second, which was equaled or exceeded for indicated percentage of time]

\begin{tabular}{cc}
\hline Streamflow & Percentage of time \\
\hline 408 & 1 \\
73 & 5 \\
21 & 10 \\
11 & 15 \\
7.4 & 20 \\
4.5 & 30 \\
3.1 & 40 \\
2.2 & 50 \\
1.5 & 60 \\
.92 & 70 \\
.56 & 80 \\
.32 & 90 \\
.15 & 95 \\
.10 & 98 \\
.09 & 99 \\
.00 & 99.5 \\
.00 & 99.9 \\
\hline
\end{tabular}

The maximum and minimum mean monthly streamflows at Agua Fria River near Rock Springs occur in February $\left(309 \mathrm{ft}^{3} / \mathrm{s}\right)$ and June $\left(4.34 \mathrm{ft}^{3} / \mathrm{s}\right)$, respectively (fig. 10). The maximum and minimum mean daily flows occur on March $1\left(1,211 \mathrm{ft}^{3} / \mathrm{s}\right)$ and July $6\left(1.61 \mathrm{ft}^{3} / \mathrm{s}\right)$, respectively (fig. 11). Daily mean flow-duration data for this site indicate that for 50 percent of the time, flow equaled or exceeded $3.5 \mathrm{ft}^{3} / \mathrm{s}$ (table 10).
Table 10. Duration of daily mean flow, Agua Fria River near Rock Springs, Arizona, 1971-73 and 1976-96

[Data from Pope and others, 1998. Streamflow, in cubic feet per second, which was equaled or exceeded for indicated percentage of time]

\begin{tabular}{cc}
\hline Streamflow & Percent of time \\
\hline 1,168 & 1 \\
309 & 5 \\
127 & 10 \\
61 & 15 \\
34 & 20 \\
13 & 30 \\
6.3 & 40 \\
3.5 & 50 \\
2.3 & 60 \\
1.5 & 70 \\
0.80 & 80 \\
0.32 & 90 \\
0.08 & 95 \\
0.00 & 98 \\
0.00 & 99 \\
0.00 & 99.5 \\
0.00 & 99.9 \\
\hline
\end{tabular}

For Agua Fria River near Mayer and Agua Fria River near Rock Springs, there is a 50-percent chance that the highest average streamflow in a continuous 30-day interval during a 2-year period will be greater than or equal to $84 \mathrm{ft}^{3} / \mathrm{s}$ and $219 \mathrm{ft}^{3} / \mathrm{s}$, respectively (tables 11 and 12). There is a 50-percent chance that the lowest average flow in a continuous 30-day interval during a 2-year period at these sites will be less than or equal to $0.42 \mathrm{ft}^{3} / \mathrm{s}$ and $0.97 \mathrm{ft}^{3} / \mathrm{s}$, respectively (tables 13 and $\mathbf{1 4}$ ).

Streamflow data were available for four of the six surface-water sites in the USGS NWIS: Agua Fria River above Arcosanti, Agua Fria River below Sycamore Creek, Agua Fria River below Bloody Basin Road at Horseshoe Ranch, and Agua Fria River near Mayer, (fig. 7 and table 15). Data for these sites indicate that flow increases along the reach of the river that extends from Arcosanti to below Sycamore Creek.

Streamflow was measured by BLM staff between June 1992 and November 1998 at 16 main-stem and tributary sites within and near the monument (fig. 7). Hydrographs and a listing of the streamflow measurements are given in appendix 3 . 


\section{Hydrologic Characteristics of the Agua Fria National Monument, Central Arizona, Reconnaissance Study}

Table 11. Magnitude and probability of high flow, Agua Fria River near Mayer, Arizona, 1941-96

[Data from Pope and others, 1998]

\begin{tabular}{|c|c|c|c|c|c|c|}
\hline \multirow[b]{2}{*}{$\begin{array}{l}\text { Period } \\
\text { (consecutive days) }\end{array}$} & \multicolumn{6}{|c|}{$\begin{array}{l}\text { Streamflow, in cubic feet per second, for indicated recurrence interval, in years } \\
\text { (non-exceedance probability, in percent) }\end{array}$} \\
\hline & $\begin{array}{l}2 \text { years } \\
\text { (50 percent) }\end{array}$ & $\begin{array}{c}5 \text { years } \\
(20 \text { percent) }\end{array}$ & $\begin{array}{c}10 \text { years } \\
\text { (10 percent) }\end{array}$ & $\begin{array}{l}25 \text { years } \\
\text { (4 percent) }\end{array}$ & $\begin{array}{l}50 \text { years } \\
(2 \text { percent })\end{array}$ & $\begin{array}{l}100 \text { years } \\
\text { (1 percent) }\end{array}$ \\
\hline 1 & 817 & 2,220 & 3,830 & 6,970 & 10,300 & 14,800 \\
\hline 3 & 399 & 1,090 & 1,880 & 3,460 & 5,170 & 7,490 \\
\hline 30 & 84 & 224 & 375 & 652 & 932 & 1,290 \\
\hline 60 & 53 & 144 & 243 & 425 & 611 & 847 \\
\hline 90 & 38 & 103 & 174 & 306 & 443 & 619 \\
\hline
\end{tabular}

Table 12. Magnitude and probability of high flow, Agua Fria River near Rock Springs, Arizona, 1971-73 and 1976-96

[Data from Pope and others, 1998]

Streamflow, in cubic feet per second, for indicated recurrence interval, in years (non-exceedance probability, in percent)

\begin{tabular}{ccccccc}
\cline { 2 - 6 } $\begin{array}{c}\text { Period } \\
\text { (consecutive days) }\end{array}$ & $\begin{array}{c}\text { 2 years } \\
\text { (50 percent) }\end{array}$ & $\begin{array}{c}\mathbf{5} \text { years } \\
\text { (20 percent) }\end{array}$ & $\begin{array}{c}\mathbf{1 0} \text { years } \\
\text { (10 percent) }\end{array}$ & $\begin{array}{c}\text { 25 years } \\
\text { (4 percent) }\end{array}$ & $\begin{array}{c}\mathbf{5 0} \text { years } \\
\text { (2 percent) }\end{array}$ & $\begin{array}{c}\mathbf{1 0 0} \text { years } \\
\text { (1 percent) }\end{array}$ \\
\hline 1 & 1,860 & 8,200 & 18,100 & 42,900 & 75,400 & 126,000 \\
3 & 957 & 4,390 & 9,760 & 22,900 & 39,900 & 65,600 \\
7 & 594 & 2,610 & 5,590 & 12,400 & 20,800 & 32,800 \\
15 & 347 & 1,540 & 3,300 & 7,410 & 12,400 & 19,700 \\
30 & 219 & 943 & 2,000 & 4,450 & 7,410 & 11,700 \\
60 & 145 & 623 & 1,330 & 2,980 & 5,020 & 8,020 \\
90 & 108 & 456 & 959 & 2,110 & 3,510 & 5,530 \\
\hline
\end{tabular}

Table 13. Magnitude and probability of low flow, Agua Fria River near Mayer, Arizona, 1941-96

[Data from Pope and others, 1998]

Streamflow, in cubic feet per second, for indicated recurrence interval, in years (non-exceedance probability, in percent)

\begin{tabular}{ccccccc}
\cline { 2 - 6 } $\begin{array}{c}\text { Period } \\
\text { (consecutive days) }\end{array}$ & $\begin{array}{c}\mathbf{2} \text { years } \\
\text { (50 percent) }\end{array}$ & $\begin{array}{c}\mathbf{5} \text { years } \\
\text { (20 percent) }\end{array}$ & $\begin{array}{c}\mathbf{1 0} \text { years } \\
\text { (10 percent) }\end{array}$ & $\begin{array}{c}\mathbf{2 0} \text { years } \\
\text { (5 percent) }\end{array}$ & $\begin{array}{c}\mathbf{5 0} \text { years } \\
\text { (2 percent) }\end{array}$ & $\begin{array}{c}\mathbf{1 0 0} \text { years } \\
\text { (1 percent) }\end{array}$ \\
\hline 1 & 0.24 & 0.10 & 0.06 & 0.00 & 0.00 & 0.00 \\
3 & .25 & .10 & .06 & .00 & .00 & .00 \\
7 & .27 & .11 & .06 & .00 & .00 & .00 \\
15 & .32 & .12 & .07 & .00 & .00 & .00 \\
30 & .42 & .17 & .10 & .00 & .00 & .00 \\
60 & .65 & .22 & .12 & .07 & .04 & .02 \\
90 & 1.00 & .34 & .18 & .10 & .05 & .03 \\
120 & 2.00 & .74 & .39 & .22 & .10 & .06 \\
183 & 4.50 & .17 & .92 & .53 & .27 & .17 \\
\hline
\end{tabular}


Table 14. Magnitude and probability of low flow, Agua Fria River near Rock Springs, Arizona, 1971-73 and 1976-96

[Data from Pope and others, 1998]

Streamflow, in cubic feet per second, for indicated recurrence interval, in years (non-exceedance probability, in percent)

\begin{tabular}{ccccccc}
\cline { 2 - 6 } $\begin{array}{c}\text { Period } \\
\text { (consecutive days) }\end{array}$ & $\begin{array}{c}\text { 2 years } \\
\text { (50 percent) }\end{array}$ & $\begin{array}{c}\mathbf{5} \text { years } \\
\text { (20 percent) }\end{array}$ & $\begin{array}{c}\mathbf{1 0} \text { years } \\
\text { (10 percent) }\end{array}$ & $\begin{array}{c}\text { 20 years } \\
\text { (5 percent) }\end{array}$ & $\begin{array}{c}\mathbf{5 0} \text { years } \\
\text { (2 percent) }\end{array}$ & $\begin{array}{c}\mathbf{1 0 0} \text { years } \\
\text { (1 percent) }\end{array}$ \\
\hline 1 & 0.60 & 0.00 & 0.00 & 0.00 & 0.00 & .00 \\
3 & .63 & .00 & .00 & .00 & .00 & .00 \\
7 & .68 & .00 & .00 & .00 & .00 & .00 \\
15 & .74 & .00 & .00 & .00 & .00 & .00 \\
30 & .97 & .00 & .00 & .00 & .00 & .00 \\
60 & 1.30 & .14 & .00 & .00 & .00 & .00 \\
90 & 1.70 & .40 & .13 & .02 & .00 & .00 \\
120 & 3.00 & .87 & .37 & .17 & .06 & .00 \\
183 & 5.10 & 1.8 & .95 & .55 & .29 & .19 \\
\hline
\end{tabular}

Table 15. Streamflow data from sites on the Agua Fria River in the Agua Fria National Monument study area, central Arizona, that were retrieved from the U.S. Geological Survey National Water Information System, 2002

\begin{tabular}{lccc}
\hline \multicolumn{1}{c}{ Site name } & Site identifier & $\begin{array}{c}\text { Streamflow } \\
\text { (cubic feet per second) }\end{array}$ & Date \\
\hline Agua Fria River above Arcosanti & USGS1 & 1.2 & $11 / 23 / 1980$ \\
Agua Fria River below Sycamore Creek & USGS3 & 3.8, & $11 / 24 / 1980$, \\
& & 1.2 & $06 / 04 / 1981$ \\
& USGS4 & 4.9 & $11 / 25 / 1980$ \\
Agua Fria River near Mayer, Arizona & (09512500) & 6.5 & $12 / 12 / 1980$ \\
Agua Fria River below Bloody Basin Road at Horseshoe Ranch & USGS6 & & \\
\hline
\end{tabular}

Streamflow measured during a seepage study in May 2002 was spatially variable but generally decreased from site AF2 to site AF14 (table 16 and figs. 7 and 17). During the seepage study, the river did not flow beyond AF14. It is assumed that the flow data represent base flow (ground-water discharge) because measurements were made following an unusually dry winter and spring.

\section{Surface-Water Quality}

Surface-water quality data for sites within and near the monument (tables 17-19) were obtained from USGS NWIS records, BLM records, and from measurements made during a seepage study in May 2002. USGS NWIS records contain stream-property and chemicalconstituent data. Stream-property data derived from BLM monitoring consist of specific-conductance, dissolved-solids, $\mathrm{pH}$, dissolved-oxygen, and turbidity values. Data from the seepage study in May 2002 include specific conductance and temperature.
Table 16. Streamflow of Agua Fria River at the seepage study sites, Agua Fria National Monument, central Arizona, May 2002

\begin{tabular}{llc}
\hline Site name & $\begin{array}{c}\text { Latitude/longitude } \\
\text { (cubic feet per second) }\end{array}$ & Streamflow \\
\hline AF1 & $34^{\circ} 19^{\prime} 30^{\prime \prime} / 112^{\circ} 04^{\prime} 20^{\prime \prime}$ & 0.39 \\
AF2 & $34^{\circ} 19^{\prime} 02^{\prime \prime} / 112^{\circ} 04^{\prime} 18^{\prime \prime}$ & 1.00 \\
AF3 & $34^{\circ} 18^{\prime} 42^{\prime \prime} / 112^{\circ} 03^{\prime} 22^{\prime \prime}$ & 0.72 \\
AF4 & $34^{\circ} 18^{\prime} 10^{\prime \prime} / 112^{\circ} 03^{\prime} 19^{\prime \prime}$ & 0.45 \\
AF5 & $34^{\circ} 17^{\prime} 17^{\prime \prime} / 112^{\circ} 03^{\prime} 20^{\prime \prime}$ & 0.37 \\
AF6 & $34^{\circ} 16^{\prime} 50^{\prime \prime} / 112^{\circ} 03^{\prime} 15^{\prime \prime}$ & 0.22 \\
AF7 & $34^{\circ} 16^{\prime} 28^{\prime \prime} / 112^{\circ} 03^{\prime} 30^{\prime \prime}$ & 0.06 \\
AF8 & $34^{\circ} 15^{\prime} 58^{\prime \prime} / 112^{\circ} 03^{\prime} 36^{\prime \prime}$ & 0.09 \\
AF9 & $34^{\circ} 15^{\prime} 28^{\prime \prime} / 112^{\circ} 03^{\prime} 41 "$ & 0.01 \\
AF10 & $34^{\circ} 14^{\prime} 48^{\prime \prime} / 112^{\circ} 03^{\prime} 41^{\prime \prime}$ & 0.14 \\
AF11 & $34^{\circ} 14^{\prime} 24^{\prime \prime} / 112^{\circ} 04^{\prime} 27^{\prime \prime}$ & 0.31 \\
AF12 & $34^{\circ} 13^{\prime} 58^{\prime \prime} / 112^{\circ} 04^{\prime} 06^{\prime \prime}$ & 0.27 \\
AF13 & $34^{\circ} 13^{\prime} 28^{\prime \prime} / 112^{\circ} 05^{\prime} 05^{\prime \prime}$ & 0.04 \\
AF14 & $34^{\circ} 13^{\prime} 18^{\prime \prime} / 112^{\circ} 05^{\prime} 20^{\prime \prime}$ & 0.03 \\
\hline
\end{tabular}


24 Hydrologic Characteristics of the Agua Fria National Monument, Central Arizona, Reconnaissance Study

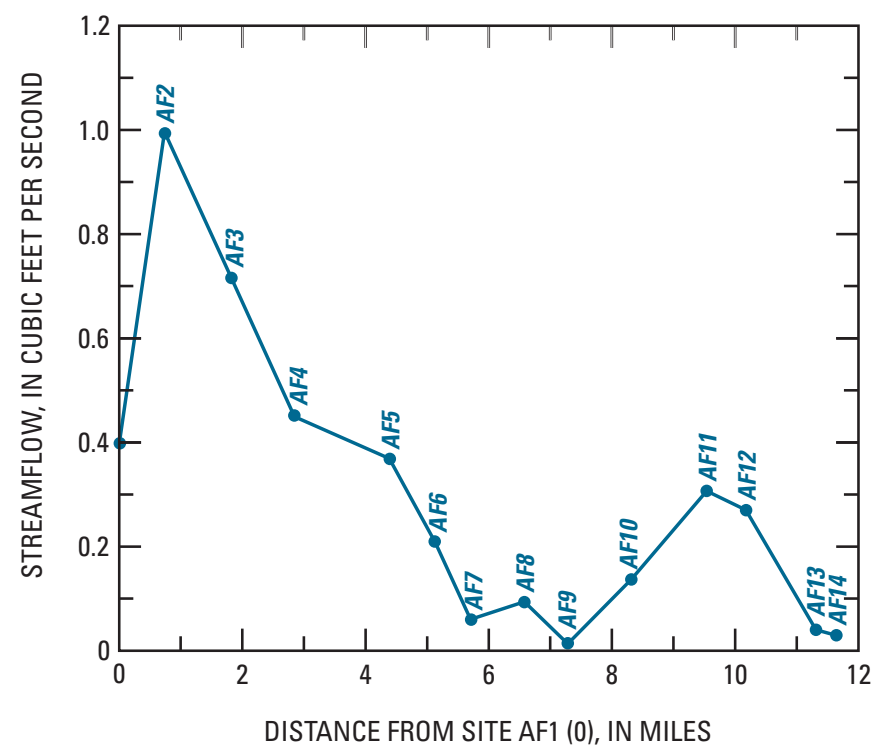

Figure 17. Streamflow of the Agua Fria River at the seepage study sites, Agua Fria National Monument, central Arizona, May 2002.

Table 17. Specific-conductance, $\mathrm{pH}$, and selected cation concentration data for sites on the Agua Fria River in the Agua Fria National Monument study area, central Arizona, that were retrieved from the U.S. Geological Survey National Water Information System, 2002

$\left[\mu \mathrm{S} / \mathrm{cm}\right.$, microsiemens per centimeter; ${ }^{\circ} \mathrm{C}$, degrees Celsius; mg/L, milligrams per liter; ---, not reported]

\begin{tabular}{lllcccc}
\hline \multicolumn{1}{c}{ Site name } & $\begin{array}{c}\text { Specific } \\
\mathbf{c o n d u c t a n c e} \\
\left(\mu \mathbf{S} / \mathbf{c m} \text { at } \mathbf{2 5}^{\circ} \mathbf{C}\right)\end{array}$ & $\mathbf{p H}$ & $\begin{array}{c}\text { Calcium } \\
(\mathbf{m g} / \mathbf{L})\end{array}$ & $\begin{array}{c}\text { Magnesium } \\
(\mathbf{m g} / \mathbf{L})\end{array}$ & $\begin{array}{c}\text { Sodium } \\
(\mathbf{m g} / \mathbf{L})\end{array}$ & $\begin{array}{c}\text { Potassium } \\
(\mathbf{m g} / \mathbf{L})\end{array}$ \\
\hline Agua Fria River above Arcosanti & 1,210 & 8.5 & 120 & 43 & 69 & 1.6 \\
Agua Fria River above Sycamore Creek & $974,1,080$ & $8.2,8.1$ & --- & --- & --- & --- \\
Agua Fria River below Sycamore Creek & 858,994 & $8.2,8.1$ & --- & --- & --- & -- \\
Agua Fria River near Mayer, Arizona & 885 & 8.6 & 78 & 35 & 47 & 2.3 \\
$\begin{array}{l}\text { Agua Fria River near Bloody Basin Road } \\
\text { Agua Fria River below Bloody Basin Road } \\
\text { at Horseshoe Ranch }\end{array}$ & ---- & --- & --- & -- & --- & -- \\
\hline
\end{tabular}


Table 18. Average stream-property values at sites in the Agua Fria National Monument study area, central Arizona, measured by Bureau of Land Management staff, June 1992 to November 1998

[ $\mu \mathrm{S} / \mathrm{cm}$, microsiemens per centimeter; NTU, nephelometric turbidity units; mg/L, milligrams per liter; ppm, parts per million; ---, not reported]

\begin{tabular}{lllccccc}
\hline \multicolumn{1}{c}{ Location } & Site identifier & $\begin{array}{c}\text { Specific } \\
\text { conductance } \\
(\mu \mathbf{S} / \mathbf{c m})\end{array}$ & $\mathbf{p H}$ & $\begin{array}{c}\text { Turbidity } \\
\text { (NTU) }\end{array}$ & $\begin{array}{c}\text { Dissolved } \\
\text { oxygen } \\
\text { (mg/L) }\end{array}$ & $\begin{array}{c}\text { Dissolved } \\
\text { oxygen } \\
\text { (percent } \\
\text { saturation) }\end{array}$ & $\begin{array}{c}\text { Dissolved } \\
\text { solids } \\
\text { (ppm) }\end{array}$ \\
\hline Dry Creek & D1 & 548 & 8.3 & 1.7 & 7.8 & 90.5 & 362 \\
Ash Creek & AA1 & 661 & 8.1 & 3.1 & 7.6 & 92.1 & 438 \\
Little Ash Creek & LA1 & 480 & 8.3 & 1.4 & 8.6 & 93.3 & 318 \\
Little Ash Creek & LA2 & 510 & 8.3 & 1.2 & 8.2 & 90.4 & 338 \\
Sycamore Creek & SC1 & 478 & 8.4 & 2.1 & 8.4 & 95.2 & 318 \\
Agua Fria River & A2 & 799 & 8.3 & 34.1 & 8.3 & 95.5 & 536 \\
Big Bug Creek & BB1 & 733 & 8.3 & 2.1 & 8.9 & 99.9 & 490 \\
Antelope Creek & AN1 & 793 & 8.2 & 1.3 & 7.6 & 86.0 & 522 \\
Indian Creek & I1 & 670 & 7.9 & 1.2 & 8.6 & 97.0 & 446 \\
Agua Fria River & A3 & 722 & 8.1 & 22.6 & 7.3 & 88.0 & 481 \\
Silver Creek & S1 & 613 & 8.3 & 1.0 & 8.4 & 96.4 & 405 \\
Larry Creek Tributary & LR1 & 596 & 8.1 & .74 & 7.3 & 86.2 & 395 \\
Larry Creek & LR2 & 775 & 8.6 & .45 & 10.6 & 102.0 & 530 \\
Agua Fria River & A5 & 623 & 8.2 & 24.2 & 7.7 & 91.5 & 411 \\
Black Canyon Creek & BCC1 & 776 & 8.4 & 1.8 & 8.3 & 97.5 & 528 \\
Black Canyon Creek & BCC2 & 283 & 8.3 &.-- & 10.0 & 102.0 & 181 \\
\hline
\end{tabular}

Table 19. Specific-conductance and temperature data for the seepage study sites along the Agua Fria River, Agua Fria National Monument, central Arizona, May 2002

$\left[\mu \mathrm{S} / \mathrm{cm}\right.$, microsiemens per centimeter; ${ }^{\circ} \mathrm{C}$, degrees Celsius; ---, not reported]

\begin{tabular}{|c|c|c|c|}
\hline Site name & Latitude/longitude & $\begin{array}{l}\text { Specific conductance } \\
\left(\mu \mathrm{S} / \mathrm{cm} \text { at } 25^{\circ} \mathrm{C}\right)\end{array}$ & Temperature $\left({ }^{\circ} \mathrm{C}\right)$ \\
\hline $\mathrm{AF} 1$ & $34^{\circ} 19^{\prime} 30^{\prime \prime} / 112^{\circ} 04^{\prime} 20^{\prime \prime}$ & 895 & 23.7 \\
\hline $\mathrm{AF} 2$ & $34^{\circ} 19^{\prime} 02^{\prime \prime} / 112^{\circ} 04^{\prime} 18^{\prime \prime}$ & 816 & 26.0 \\
\hline $\mathrm{AF} 3$ & $34^{\circ} 18^{\prime} 42^{\prime \prime} / 112^{\circ} 03^{\prime} 22^{\prime \prime}$ & --- & 26.0 \\
\hline AF4 & $34^{\circ} 18^{\prime} 10^{\prime \prime} / 112^{\circ} 03^{\prime} 19^{\prime \prime}$ & 892 & 17.0 \\
\hline AF5 & $34^{\circ} 17^{\prime} 17^{\prime \prime} / 112^{\circ} 03^{\prime} 20^{\prime \prime}$ & 891 & 20.0 \\
\hline AF6 & $34^{\circ} 16^{\prime} 50^{\prime \prime} / 112^{\circ} 03^{\prime} 15^{\prime \prime}$ & 959 & 24.6 \\
\hline AF7 & $34^{\circ} 16^{\prime} 28^{\prime \prime} / 112^{\circ} 03^{\prime} 30^{\prime \prime}$ & 1,037 & 26.4 \\
\hline AF8 & $34^{\circ} 15^{\prime} 58^{\prime \prime} / 112^{\circ} 03^{\prime} 36^{\prime \prime}$ & 945 & 24.7 \\
\hline AF9 & $34^{\circ} 15^{\prime} 28^{\prime \prime} / 112^{\circ} 03^{\prime} 41^{\prime \prime}$ & 944 & 22.0 \\
\hline AF10 & $34^{\circ} 14^{\prime} 48^{\prime \prime} / 112^{\circ} 03^{\prime} 41^{\prime \prime}$ & 1,005 & 28.0 \\
\hline AF11 & $34^{\circ} 14^{\prime} 24^{\prime \prime} / 112^{\circ} 04^{\prime} 27^{\prime \prime}$ & 958 & 24.0 \\
\hline AF12 & $34^{\circ} 13^{\prime} 58^{\prime \prime} / 112^{\circ} 04^{\prime} 06^{\prime \prime}$ & 943 & 18.7 \\
\hline $\mathrm{AF} 13$ & $34^{\circ} 13^{\prime} 28^{\prime \prime} / 112^{\circ} 05^{\prime} 05^{\prime \prime}$ & 905 & 20.0 \\
\hline AF14 & $34^{\circ} 13^{\prime} 18^{\prime \prime} / 112^{\circ} 05^{\prime} 20^{\prime \prime}$ & 908 & 22.5 \\
\hline
\end{tabular}




\section{Hydrologic Characteristics of the Agua Fria National Monument, Central Arizona, Reconnaissance Study}

The Arizona Department of Environmental Quality (ADEQ) assigns specific designated uses to reaches of major streams in Arizona (State of Arizona, 1996). Within the monument, designated uses for the Agua Fria River are domestic water use, full body contact, aquatic and wildlife (warm water fishery), fish consumption, agricultural irrigation, and agricultural livestock watering. Several tributaries, including Little Ash Creek, Sycamore Creek, Big Bug Creek, Antelope Creek, and Black Canyon Creek, have similar designations. Waterquality standards for each stream property (for example: $\mathrm{pH}$, turbidity, and dissolved-oxygen concentration) and certain chemical constituents vary by designated use.

Water-quality data for the six sites that were identified from USGS NWIS queries included values for specific conductance, $\mathrm{pH}$, and selected cation concentrations (calcium, magnesium, sodium, and potassium; table 17). The reported $\mathrm{pH}$ values are within the State of Arizona water-quality standards for the designated uses. Specific-conductance values decrease in the downstream direction.

Average values of stream properties for tributary and main-stem BLM monitoring sites did not exceed the State of Arizona water-quality standards for aquatic and wildlife (warm water fishery) use (table 18). In a few instances, however, discrete values exceeded these standards. Dissolved-oxygen concentrations did not meet the standard (minimum $6.0 \mathrm{mg} / \mathrm{L}$ and percent saturation less than 90 percent) one or more times at LA2 (Little Ash Creek), A3 (Agua Fria River), and BCC1 (Black Canyon Creek). The $\mathrm{pH}$ exceeded the maximum allowable value (9.0) on two occasions at A5 on the Agua Fria River (appendix 3). Average specificconductance values for the Agua Fria River decreased in the downstream direction. No other consistent trends, however, were noted in the other analyses.

Specific-conductance values obtained during the seepage study in May 2002 (table 19) are consistent with those from the USGS NWIS and the BLM monitoring data sets. No consistent trend is noted with respect to sampling location.

\section{Ground-Water/Surface-Water Interaction}

The duration and magnitude of streamflow within the monument are influenced by streamflow at the northern boundary of the monument, tributary inflows within the monument, hydraulic connection with the subsurface water-bearing zones, precipitation, and vegetation. On the basis of field observations, inflows to the river from tributaries are ephemeral, and the frequency and magnitude of these flows likely reflect the seasonal distribution of precipitation. The degree of bedrock fracturing and the occurrence and distribution of alluvium within the river canyon influence the efficacy of hydraulic connection with subsurface water-bearing zones. Tributary streamflow to the river and recharge to the subsurface occur as concentrated runoff and direct infiltration of precipitation. The amount of recharge represents some fraction of annual precipitation.

Inflows to the monument include streamflow and ground-water inflow at the northern boundary, ephemeral streamflow from tributary canyons in response to precipitation, and ground-water underflow from alluvium in tributary canyons. Outflows from the monument include streamflow and ground-water underflow at the southern boundary, ground-water pumpage, and evapotranspiration from riparian vegetation. Anning and Duet (1994) reported that annual ground-water withdrawals in the Agua Fria Basin for 1987-90 ranged from 3,000 to 9,000 acre-ft.

Field observations of the Agua Fria River canyon in the monument indicate that the river is most likely to be perennial where bedrock is at shallow depths below the river or constricts the canyon, because streamflow losses to infiltration in these areas are small. This tendency is moderated by the presence of riparian vegetation, which could reduce streamflow when evaportanspiration rates are high. The extent to which surface-water diversions or ground-water pumping influences streamflow is unknown.

Alluvial deposits within the river channel vary in composition and are discontinuous. In areas where streamflow tends to diminish or cease altogether, sediments generally are highly permeable, well sorted, angular to subangular, medium- to coarse-grained sand. The sediments appear to have derived from the surrounding outcrops, but much of the material could have been transported from sources upstream.

On the basis of observed flow during and following one of the driest years on record, only the most upstream portion of the river within the monument (closest to the northern boundary) appears to be perennial, and downstream reaches appear to be intermittent. Flow duration in downstream reaches is likely controlled by precipitation within the drainage area and by the lithology of surface and subsurface rocks in the drainage area, the geometry of the river channel, and the thickness of alluvial sediments underlying and adjacent to the channel. During a site visit in May 2002, streamflow 
was continuous from a point upstream from the northern boundary of the monument to below the USGS streamflow-gaging station near Mayer, Arizona. Downstream from this point, however, streamflow became intermittent as a function of downstream position and was altogether absent about $0.6 \mathrm{mi}$ upstream from the well that supplies water for a rest area on Interstate 17.

\section{Considerations for Further Study}

Currently (2004) available data provide a general overview of hydrologic conditions within the monument. The likely influence of surface-water/ground-water interactions on variations in surface-water conditions along the Agua Fria River within the monument suggest the need for additional study to better describe the hydrogeology of the area. No active studies that involve hydrologic data collection within the monument were identified. Development of programs for collection of geologic, surface-water, ground-water, and water-quality data would benefit the BLM efforts to manage the water resources in the monument.

The USGS streamflow-gaging station Agua Fria River near Mayer, Arizona, near the northern boundary of the monument has been in continuous operation since 1940 and provides measurements of surface-water inflow to the monument. A station near the southern boundary would provide measurements of surface-water outflow from the monument.

Additional measurements of streamflow that include periods of maximum and minimum evapotranspiration could be made over a period of several years to aid in quantification of water losses due to evaportanspiration. These measurements could also be used to help identify possible geologic controls that affect streamflow and identify losses to other sinks such as ground-water pumping.

A synoptic well and spring inventory could be used to gain a better understanding of the current ground-water conditions in the monument area. Data obtained from such an effort could include not only an inventory of wells and springs, but also water levels, water-quality information, and spring discharge. These data could provide useful baseline information for establishing a Federal Reserve water right for the monument.

Installation and monitoring of piezometers would provide information about vertical and horizontal head gradients adjacent to and beneath the Agua Fria River. This information would further aid in identifying areas of streamflow gains and losses. Monitoring changes in ground-water levels could also provide information on consumptive transpiration demands along selected reaches of the river. Additional water-quality samples could be collected from the piezometers in these transects.

Surface geophysical surveys could be used to determine the geometry of the alluvial aquifer to better characterize the important geologic controls affecting surface-water/ground-water interactions. Possible geophysical survey methods include seismic refraction, direct-current electrical resistivity, or electromagnetic induction. Results from these surveys could also be used to estimate the amount of ground-water flow through the study area.

\section{Summary}

Existing hydrologic and surface-water data collected during May 2002 for the reconnaissance study were used to characterize the hydrology of the Agua Fria National Monument. This information will be used by the BLM to help support future water-resource management responsibilities, including quantification of a Federal Reserve water right within the monument, and to guide potential future data-collection programs.

Currently (2004), few hydrologic and hydrogeologic data are available for the monument. The USGS streamflow-gaging station near Mayer, Arizona, has been in continuous operation since 1940 and provides measurements of surface-water inflow to the monument. Water-quality data are also available for this site. Measurements of streamflow and specific conductance were made along the Agua Fria River within the monument in May 2002. The data indicate that upstream reaches of the river near the northern boundary of the monument are perennial, and that streamflow generally decreases in the downstream direction as water infiltrates the streambed.

With the exception of a few measurements of dissolved oxygen and $\mathrm{pH}$, the surface-water quality data collected by the BLM and USGS indicate that values did not exceed State of Arizona standards. Few data are available, however, for wells and springs in the monument. Well-drillers' logs were generally in good agreement with the mapped geology.

Additional data collection and analysis would increase the understanding of hydrologic processes within the monument. This could include the construction and operation of a streamflow-gaging station near the southern boundary of the monument, a synoptic well and spring inventory, additional surface-water data collection, installation and monitoring of piezometers, and surface geophysical surveys. 


\section{Hydrologic Characteristics of the Agua Fria National Monument, Central Arizona, Reconnaissance Study}

\section{References Cited}

Anderson C.A., and Blacet, P.M., 1972, Geologic map of the Mayer quadrangle, Yavapai County, Arizona: U.S. Geological Survey Geologic Quadrangle Map GQ-996, scale 1:62,500.

Anning, D.W., and Duet, N.R., 1994, Summary of groundwater conditions in Arizona, 1987-90: U.S. Geological Survey Open-File Report 94-476, 2 sheets, scale 1:1,000,000.

Arizona Bureau of Mines, 1958, Geologic map of Yavapai County, Arizona: Tucson, Arizona Bureau of Mines, University of Arizona, scale 1:375,000.

Barnett, L.O., Hawkins, R.H., and Guertin, D.P., 2003, Reconnaissance watershed and hydrologic analysis on the upper Agua Fria watershed: Tucson, School of Renewable Natural Resources, University of Arizona, 62 p.

Brown, D.E., Carmony, N.B., and Turner, R.M., 1981, Drainage map of Arizona showing perennial streams and some important wetlands: Phoenix, Arizona Game and Fish Department, 1 sheet, scale 1:1,000,000.

Fenneman, N.M., 1931, Physiography of the Western United States: New York, McGraw-Hill, 543 p.

Halvorson,W., Thomas, K., and Graham, L. 2001, Arizona GAP analysis project vegetation map, part of the special technical report, the Arizona GAP project final report: Tucson, U.S. Geological Survey Sonoran Desert Field Station, University of Arizona.

León, Elizabeth, Ferré, T.P.A., 2003, A conceptual model of groundwater flow in the upper Agua Fria Watershed, report prepared for the Arizona Department of Water Resources, accessed January 7, 2004, at http://www.water.az.gov/ watershed/content/map/documents/AFconceptmodel.pdf

Littin, G.R., 1981, Maps showing ground-water conditions in the Agua Fria areas, Yavapai and Maricopa Counties, Arizona-1979: U.S. Geological Survey Water-Resources Investigations Report, 81-804, 2 sheets, scale 1:250,000.

Pope, G.L., Rigas, P.D., and Smith, C.F., 1998, Statistical summaries of streamflow data and characteristics of drainage basins for selected streamflow-gaging stations in Arizona through water year 1996: U.S. Geological Survey Water-Resources Investigations Report, 98-4225, 907 p.
Rantz, S.E., and others, 1982, Measurement and computation of streamflow_Volume 1, Measurement of stage and discharge: U.S. Geological Survey Water-Supply Paper 2175, $248 \mathrm{p}$.

Reynolds, S.J., 1988, Geologic map of Arizona: Arizona Geologic Survey, Map 26, scale 1:1,000,000.

Richard, S.M., Reynolds, S.J., Spencer, J.E., and Pearthree, P.A., 2000, Geologic map of Arizona: Tucson, Arizona, Geological Survey Map M-35, scale 1:1,000,000.

Sellers, W.D., and Hill, R.H., eds., 1974, Arizona climate 1931-1972: Tucson, University of Arizona Press, 616 p.

Smith, C.F., Duet, N.R., Fisk, G.G., McCormack, H.F., Partin, C.K., Pope, G.L., and Rigas, P.D., 1997, Water resources data for Arizona, water year 1996: U.S. Geological Survey Water-Data Report, AZ-96-1, 328 p.

State of Arizona, 1996, Water quality standards: Phoenix, State of Arizona, Arizona Administrative Code, Title 18, chap. 11, p. 1-60.

University of Arizona Institute of Atmospheric Physics, 2003, Arizona weather stations on land resource map, Tucson, Arizona, accessed March 12, 2004, at http://ag2.calsnet. arizona.edu/Weather/azmaps/azmap.html

Valencia, R.A., Wennerlund, J.A., Winstead, R.A., Woods, S., Riley, L., Swanson, E., and Olson, S., 1993, Arizona riparian inventory and mapping project: Phoenix, Arizona Game and Fish Department, 138 p.

Wahl, C.R., Boe, S.R., Wennerlund, J.A., Winstead, R.A., Allison, L.J., Kubly, D.M., 1997, Remote sensing mapping of Arizona intermittent stream riparian areas: Phoenix, Arizona Game and Fish Department, 58 p.

Western Regional Climate Center, Desert Research Institute, 2004, Arizona climate summaries: Reno, Nevada, accessed April 15, 2004, at http://www.wrcc.dri.edu/climsum.html

Wilde, F.D., and Radtke, D.B., eds., 1998, National field manual for the collection of water-quality data-Field measurements: U.S. Geological Survey Techniques of Water-Resources Investigations, book 9, chap. A6, v.p.

Wilson, R.P., 1988, Water resources of the northern part of the Agua Fria area, Yavapai County, Arizona: Phoenix, Arizona Department of Water Resources Bulletin 5, 109 p. 


\section{Appendix 1}

Summary of drillers' logs for wells within the Agua Fria National Monument, central Arizona

[Source: Arizona Department of Water Resources]

\begin{tabular}{cccl}
\hline Well number & $\begin{array}{c}\text { Depth from } \\
\text { (feet) }\end{array}$ & $\begin{array}{c}\text { Depth to } \\
\text { (feet) }\end{array}$ & Description of formation material \\
\hline (A-11-03)21dba & 0 & 10 & Sands \\
& 10 & 125 & Hard rock and granite \\
& 125 & 135 & Granite \\
& 135 & 210 & Hard rock and granite \\
\hline (A-11-03)28bbd & 0 & 60 & Sand and river rock \\
& 60 & 210 & Granite and cascading sand \\
\hline (A-10-02)24acc & 0 & 39 & Topsoil \\
& 2 & 160 & Cemented conglomerate \\
& 39 & 8 & Red granite \\
\hline (A-09-03)a & 0 & 206 & Surface silt and boulders \\
& 8 & 316 & Basalt and cinders \\
& 206 & 355 & Layers of altered basalt mixed with granite layers \\
& 316 & 395 & Basalt, fractured with calcite and ash \\
& 355 & 416 & Basalt, fractured (water at 385-390) \\
\hline (A-09-03)19cbc & 165 & Hard black basalt \\
\hline & 0 & 470 & Overburden-volcanic rock, sand, and gravel \\
& 165 & Volcanic rock, granite and black Malapai \\
\hline
\end{tabular}


This page left blank intentionally. 


\section{Appendix 2}

Ground-water quality data for wells in the Agua Fria National Monument study area, central Arizona

[ $\mu \mathrm{S} / \mathrm{cm}$, microsiemens per centimeter; $\mathrm{mg} / \mathrm{L}$, milligrams per liter; ---, not reported]

\begin{tabular}{|c|c|c|c|c|c|c|c|c|}
\hline \multirow[b]{2}{*}{ Well number } & \multirow{2}{*}{$\begin{array}{c}\text { Well } \\
\text { altitude } \\
\text { (feet) }\end{array}$} & \multirow[b]{2}{*}{ Sampling date } & \multirow{2}{*}{$\begin{array}{l}\text { Depth to } \\
\text { water } \\
\text { (feet) }\end{array}$} & \multirow{2}{*}{$\begin{array}{l}\text { Water level } \\
\text { altitude } \\
\text { (feet) }\end{array}$} & \multicolumn{2}{|c|}{ Zone 12} & \multirow{2}{*}{$\begin{array}{c}\text { Specific } \\
\text { conductance } \\
(\mu \mathrm{S} / \mathrm{cm})\end{array}$} & \multirow[b]{2}{*}{$\begin{array}{c}\text { Fluoride } \\
\text { (mg/L) }\end{array}$} \\
\hline & & & & & $\begin{array}{l}\text { UTM } \\
\text { Easting }\end{array}$ & $\begin{array}{l}\text { UTM } \\
\text { Northing }\end{array}$ & & \\
\hline (A-11-02)25bdd & 3,700 & $05 / 18 / 1977$ & 123 & 3,577 & 399052 & 3795675 & 490 & 0.6 \\
\hline (A-09-02)26ddd & 2,050 & 05/03/1978 & 9 & 2,041 & 396983 & 3772026 & 510 & .5 \\
\hline (A-11-02)14dac & 3,760 & 05/24/1977 & 55 & 3,705 & 397445 & 3799155 & 510 & .5 \\
\hline (A-09-02)35bcb1 & 2,040 & 04/28/1978 & 32 & 2,008 & 395542 & 3771483 & 545 & .5 \\
\hline (A-09-02)35baa & 2,030 & 05/04/1978 & 14 & 2,016 & 396173 & 3771832 & 620 & .5 \\
\hline$(\mathrm{A}-11-02) 14 \mathrm{ccd} 1$ & 3,760 & 05/25/1977 & 17 & 3,743 & 396431 & 3798781 & 620 & .6 \\
\hline (A-09-02)34dda & 2,020 & 05/04/1978 & 37 & 1,983 & 395322 & 3770649 & 705 & .6 \\
\hline (A-09-02)34daa1 & 2,020 & 05/04/1978 & 15 & 2,005 & 395322 & 3771066 & 730 & .4 \\
\hline (A-09H02)36cda1 & 2,440 & 05/19/1978 & 27 & 2,413 & 397870 & 3780290 & 740 & .3 \\
\hline (A-09-02)34dac1 & 2,010 & 04/28/1978 & 13 & 1,997 & 395059 & 3770847 & 750 & .5 \\
\hline (A-11-03)18ada & 3,555 & 05/23/1977 & 22 & 3,533 & 400854 & 3799462 & 785 & .4 \\
\hline$(\mathrm{A}-09-02) 35 \mathrm{bdb}$ & 2,020 & 05/04/1978 & 19 & 2,001 & 395968 & 3771431 & 790 & .5 \\
\hline (A-09-02)34dad & 2,020 & 05/02/1978 & 15 & 2,005 & 395344 & 3770847 & 860 & .5 \\
\hline$(\mathrm{A}-08-02) 03 \mathrm{dbd} 2$ & 2,030 & 04/20/1978 & 22 & 2,008 & 394778 & 3769469 & 870 & .5 \\
\hline (A-09-02)25bdc & 2,110 & 05/04/1978 & 17 & 2,094 & 397799 & 3772819 & 900 & .5 \\
\hline$(\mathrm{A}-09-02) 34 \mathrm{ccd} 2$ & 1,980 & $04 / 21 / 1978$ & 17 & 1,963 & 394093 & 3770429 & 950 & .5 \\
\hline (A-09-02)24dcd2 & 2,080 & 05/03/1978 & 25 & 2,055 & 398111 & 3773720 & 990 & .5 \\
\hline (A-08-02)10cba & 1,950 & 04/20/1978 & 70 & 1,880 & 394049 & 3768255 & 1,040 & .5 \\
\hline (A-11-02)12bda & 3,620 & 05/23/1977 & 25 & 3,595 & 398492 & 3801400 & 1,300 & 1.3 \\
\hline (A-09-02)28aab1 & 2,000 & 04/28/1978 & 29 & 1,971 & 393560 & 3773482 & 2,120 & 11.5 \\
\hline (A-09-02)27cba & 2,030 & 05/02/1978 & 0 & 2,030 & 393983 & 3772713 & 2,950 & 14.0 \\
\hline (A-09-02)34aba & 2,060 & 04/28/1978 & 0 & 2,060 & 394905 & 3771857 & 3,380 & 3.7 \\
\hline
\end{tabular}


This page left blank intentionally. 


\section{Appendix 3}

Bureau of Land Management field-measured water properties and streamflow data from sites in the Agua Fria National Monument study area, central Arizona

Site AA1, Ash Creek, Arizona

$\left[\mu \mathrm{S} / \mathrm{cm}\right.$, microsiemens per centimeter; ${ }^{\circ} \mathrm{C}$, degrees Celsius; NTU, nephelometric turbidity units; $\mathrm{mg} / \mathrm{L}$, milligrams per liter; ppm, parts per million; $\mathrm{ft}^{3} / \mathrm{s}$, cubic feet per second; ---, not reported]

\begin{tabular}{|c|c|c|c|c|c|c|c|c|c|}
\hline Date & Time & $\begin{array}{c}\text { Specific } \\
\text { conductance } \\
(\mu \mathrm{S} / \mathrm{cm})\end{array}$ & $\mathrm{pH}$ & $\begin{array}{c}\text { Air/water } \\
\text { temperature } \\
\left({ }^{\circ} \mathrm{C}\right)\end{array}$ & $\begin{array}{c}\text { Turbidity } \\
\text { (NTU) }\end{array}$ & $\begin{array}{c}\text { Dissolved } \\
\text { oxygen } \\
\text { (mg/L) }\end{array}$ & $\begin{array}{l}\text { Dissolved } \\
\text { oxygen } \\
\text { (percent } \\
\text { saturation) }\end{array}$ & $\begin{array}{l}\text { Dissolved } \\
\text { solids } \\
\text { (ppm) }\end{array}$ & $\begin{array}{c}\text { Discharge } \\
\left(\mathrm{ft}^{3} / \mathrm{s}\right)\end{array}$ \\
\hline $09 / 05 / 92$ & 1615 & 638 & 8.1 & $22.0 / 27.0$ & --- & 6.9 & 90 & 440 & 0.25 \\
\hline 09/25/92 & 1215 & 628 & 7.6 & $28.0 / 23.0$ & --- & 5.9 & 78 & 430 & 1.00 \\
\hline 03/18/93 & 0900 & 590 & 8.5 & $10.5 / 11.5$ & 3.10 & 10.0 & 104 & 390 & 17.80 \\
\hline 06/04/93 & 1215 & 670 & 8.1 & $24.5 / 22.5$ & 1.07 & 7.4 & 97 & 440 & 1.96 \\
\hline 08/05/93 & 1230 & 650 & 7.9 & $29.0 / 22.3$ & 0.56 & 6.9 & 90 & 430 & 1.58 \\
\hline 09/16/93 & 1000 & 720 & 8.2 & 23.0/19.0 & 3.70 & 6.7 & 83 & 480 & 1.75 \\
\hline $12 / 07 / 93$ & 1445 & 670 & 8.3 & $18.0 / 15.0$ & 1.11 & 7.2 & 81 & 440 & 1.83 \\
\hline 03/09/94 & 1110 & 640 & 8.2 & $16.0 / 14.5$ & 0.51 & 8.3 & 94 & 420 & 2.42 \\
\hline 06/07/94 & 1105 & 730 & 8.2 & $28.0 / 21.5$ & 0.69 & 7.6 & 98 & 480 & 1.45 \\
\hline 09/13/94 & 1235 & 750 & 7.8 & $26.5 / 24.0$ & 3.17 & 6.3 & 86 & 500 & 1.50 \\
\hline $12 / 20 / 94$ & 1400 & 580 & 8.6 & $19.0 / 15.0$ & 2.50 & 8.2 & 94 & 380 & 1.30 \\
\hline $01 / 13 / 95$ & 1105 & 660 & 8.3 & $15.5 / 15.0$ & 2.05 & 8.5 & 97 & 440 & 1.49 \\
\hline $02 / 08 / 95$ & 1240 & 670 & 8.2 & $17.5 / 17.0$ & 1.26 & 7.8 & 92 & 440 & 1.76 \\
\hline 03/02/95 & 1220 & 620 & 8.2 & $15.0 / 16.0$ & 16.70 & --- & --- & 410 & 7.87 \\
\hline $04 / 03 / 95$ & 1050 & 650 & 8.3 & $20.0 / 17.5$ & 2.01 & 8.4 & 100 & 430 & 3.10 \\
\hline 05/03/95 & 1330 & 670 & 8.2 & $25.0 / 25.0$ & 1.51 & --- & --- & 440 & 1.88 \\
\hline 06/01/95 & 0820 & 650 & 8.3 & 21.0/17.0 & 1.02 & 8.2 & 98 & 430 & 1.66 \\
\hline 07/12/95 & 0945 & 660 & 7.9 & $27.0 / 22.5$ & 0.97 & --- & --- & 440 & 1.50 \\
\hline 08/08/95 & 0915 & 670 & 7.9 & $28.0 / 22.5$ & 1.33 & --- & --- & 440 & 1.13 \\
\hline 09/08/95 & 0925 & 680 & 8.1 & $26.0 / 22.5$ & 13.9 & --- & --- & 450 & 1.51 \\
\hline 10/03/95 & 0945 & 680 & 8.2 & 20.0/19.0 & 2.06 & --- & --- & 450 & 1.46 \\
\hline
\end{tabular}


Site AA1, Ash Creek, Arizona-Continued

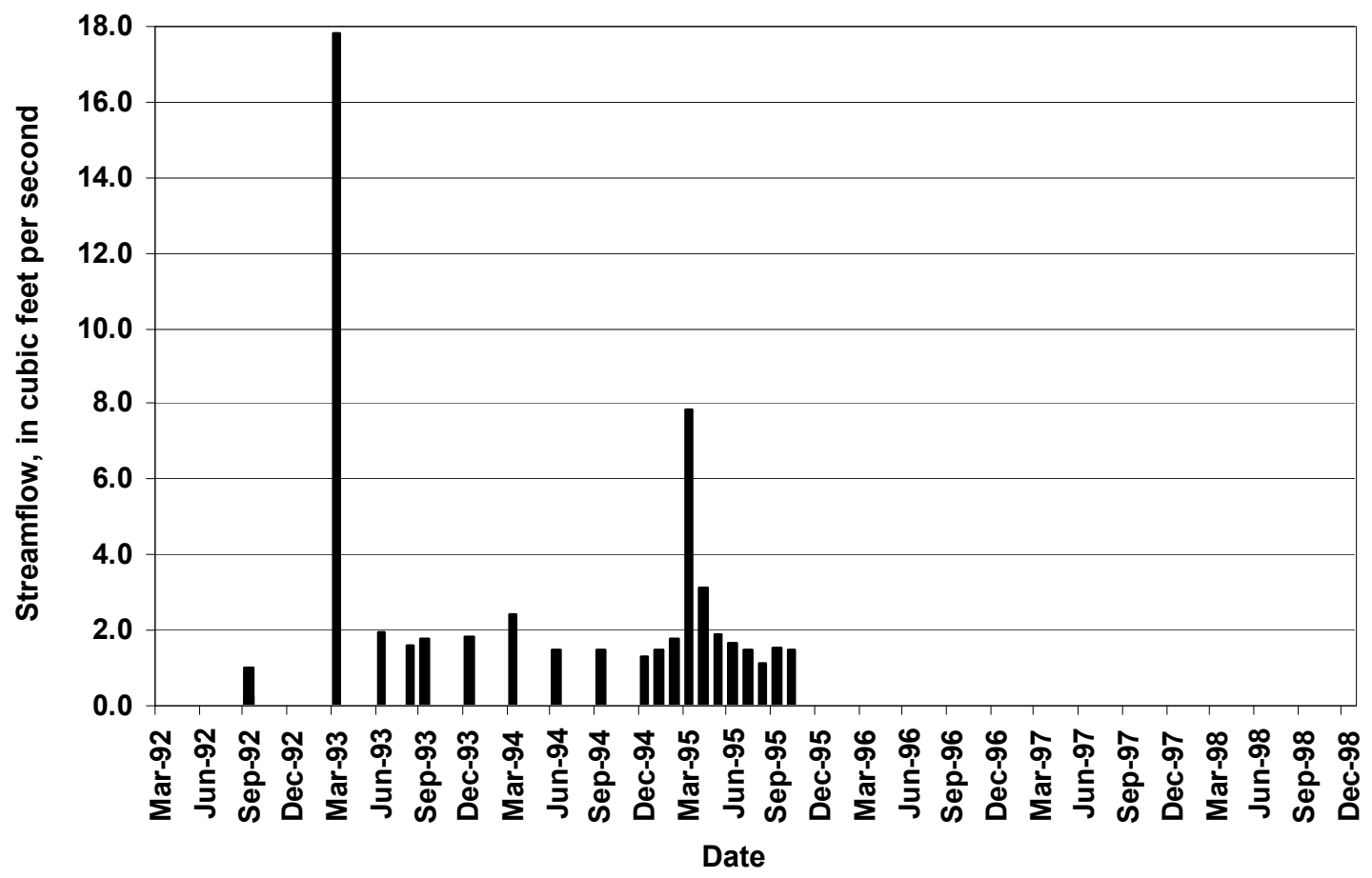


Site D1, Dry Creek, Arizona

$\left[\mu \mathrm{S} / \mathrm{cm}\right.$, microsiemens per centimeter; ${ }^{\circ} \mathrm{C}$, degrees Celsius; NTU, nephelometric turbidity units; $\mathrm{mg} / \mathrm{L}$, milligrams per liter; ppm, parts per million; $\mathrm{ft}^{3} / \mathrm{s}, \mathrm{cubic}$ feet per second; ---, not reported]

\begin{tabular}{|c|c|c|c|c|c|c|c|c|c|}
\hline Date & Time & $\begin{array}{c}\text { Specific } \\
\text { conductance } \\
(\mu \mathrm{S} / \mathrm{cm})\end{array}$ & $\mathrm{pH}$ & $\begin{array}{c}\text { Air/water } \\
\text { temperature } \\
\left({ }^{\circ} \mathrm{C}\right)\end{array}$ & $\begin{array}{l}\text { Turbidity } \\
\text { (NTU) }\end{array}$ & $\begin{array}{c}\text { Dissolved } \\
\text { oxygen } \\
\text { (mg/L) }\end{array}$ & $\begin{array}{c}\text { Dissolved } \\
\text { oxygen } \\
\text { (percent } \\
\text { saturation) }\end{array}$ & $\begin{array}{l}\text { Dissolved } \\
\text { solids } \\
\text { (ppm) }\end{array}$ & $\begin{array}{c}\text { Discharge } \\
\left(\mathrm{ft}^{3} / \mathrm{s}\right)\end{array}$ \\
\hline $10 / 05 / 92$ & 1415 & 494 & 8.4 & $27.0 / 21.0$ & --- & $19.2 ?$ & --- & 340 & 0.18 \\
\hline $01 / 25 / 93$ & 1000 & 620 & 8.3 & $9.5 / 8.0$ & 2.47 & 8.2 & 79 & 410 & 0.37 \\
\hline 06/04/93 & 1045 & 550 & 8.6 & $24.0 / 19.5$ & 2.23 & 8.1 & 100 & 360 & 0.26 \\
\hline 08/05/93 & 1630 & 570 & 8.2 & $27.0 / 24.0$ & 0.95 & 5.7 & 77 & 380 & 0.2 \\
\hline 09/22/93 & 1030 & 550 & 8.5 & $26.0 / 18.5$ & 1.14 & 7.5 & 92 & 360 & 0.13 \\
\hline $12 / 07 / 93$ & 1220 & 510 & 8.5 & $16.5 / 12.5$ & 0.52 & 9.3 & 99 & 340 & 0.26 \\
\hline 03/09/94 & 0935 & 520 & 8.4 & $12.0 / 11.0$ & 0.62 & 9.5 & 99 & 340 & 0.28 \\
\hline 06/07/94 & 0925 & 560 & 8.4 & $26.0 / 17.5$ & 2.18 & 7.9 & 94 & 370 & 0.21 \\
\hline 09/13/94 & 0950 & 620 & 8.2 & $23.5 / 20.0$ & 1.07 & 7.5 & 95 & 410 & 0.22 \\
\hline 02/09/95 & 1150 & 530 & 8.4 & $17.0 / 14.0$ & 4.67 & 7.5 & 83 & 350 & 0.19 \\
\hline 06/07/95 & 1000 & 530 & 8.1 & $21.0 / 18.5$ & 0.76 & 7.2 & 87 & 350 & 0.20 \\
\hline 10/03/95 & 1305 & 530 & 8.2 & $25.5 / 24.0$ & 2.51 & --- & --- & 350 & 0.15 \\
\hline $11 / 04 / 98$ & 1210 & 540 & 8.2 & $18.0 / 15.0$ & --- & --- & --- & 350 & 0.17 \\
\hline
\end{tabular}

${ }^{1}$ Value was marked with a "?" by the Bureau of Land Management.

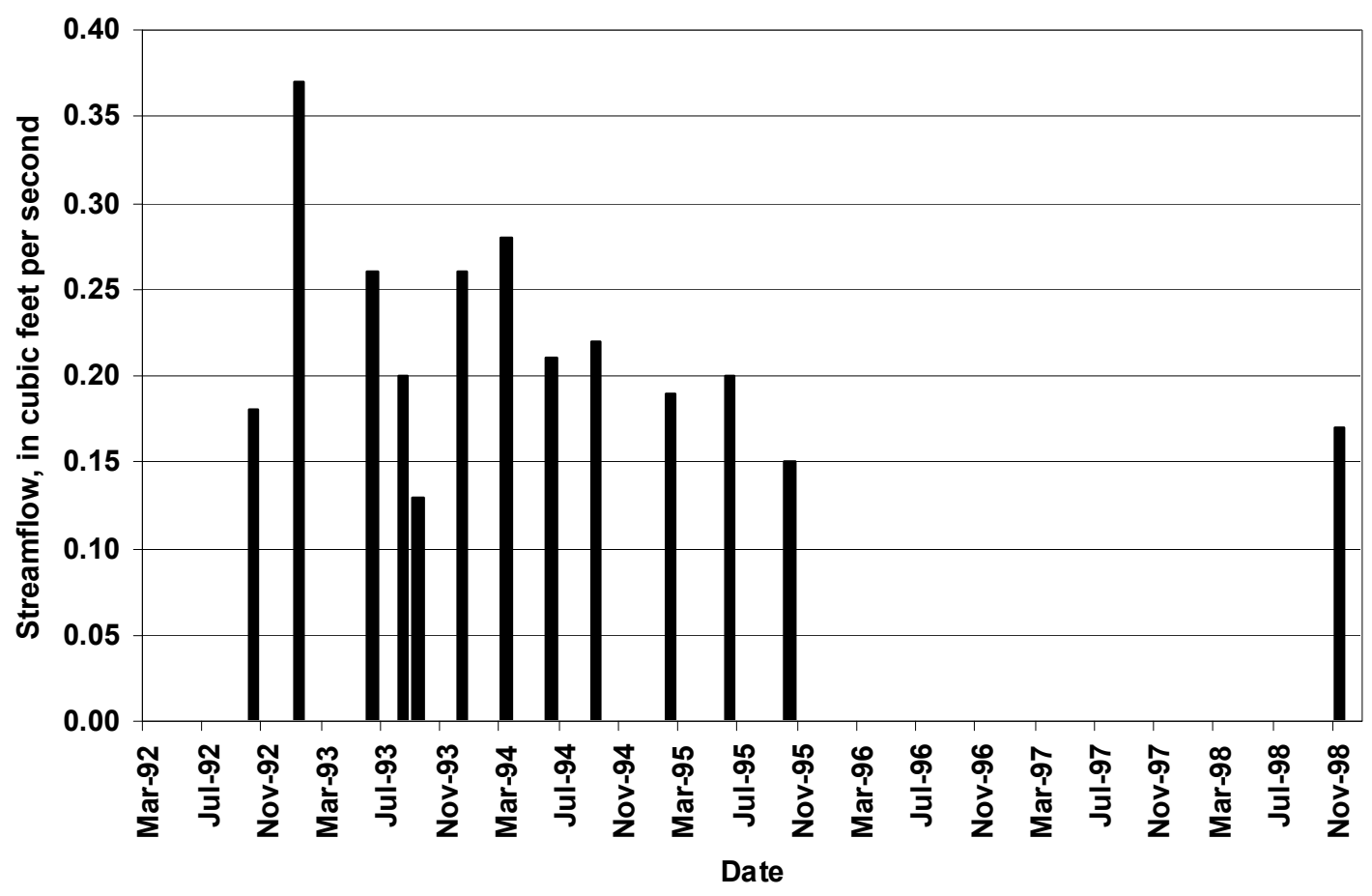




\section{Hydrologic Characteristics of the Agua Fria National Monument, Central Arizona, Reconnaissance Study}

Site LA 1, Little Ash Creek, Arizona

$\left[\mu \mathrm{S} / \mathrm{cm}\right.$, microsiemens per centimeter; ${ }^{\circ} \mathrm{C}$, degrees Celsius; NTU, nephelometric turbidity units; $\mathrm{mg} / \mathrm{L}$, milligrams per liter; ppm, parts per million; $\mathrm{ft}{ }^{3} / \mathrm{s}$, cubic feet per second; ---, not reported]

\begin{tabular}{cccccccccc}
\hline Date & Time & $\begin{array}{c}\text { Specific } \\
\text { conductance } \\
(\mu \mathbf{S} / \mathbf{c m})\end{array}$ & $\mathbf{p H}$ & $\begin{array}{c}\text { Air/water } \\
\text { temperature } \\
\left({ }^{\circ} \mathbf{C}\right)\end{array}$ & $\begin{array}{c}\text { Turbidity } \\
(\mathbf{N T U})\end{array}$ & $\begin{array}{c}\text { Dissolved } \\
\mathbf{0 x y g e n} \\
(\mathbf{m g} / \mathbf{L})\end{array}$ & $\begin{array}{c}\text { Dissolved } \\
\mathbf{0 x y g e n} \\
\text { (percent } \\
\text { saturation) }\end{array}$ & $\begin{array}{c}\text { Dissolved } \\
\mathbf{s o l i d s} \\
(\mathbf{p p m})\end{array}$ & $\begin{array}{c}\text { Discharge } \\
\left(\mathbf{f t}^{3} \mathbf{s}\right)\end{array}$ \\
\hline $10 / 05 / 92$ & 1330 & 488 & 8.4 & $26.0 / 21.0$ & --- & $19.4 ?$ & --- & 330 & 0.04 \\
$01 / 25 / 93$ & 1130 & 400 & 8.4 & $10.0 / 4.5$ & 0.51 & 9.5 & 83 & 260 & 1.80 \\
$06 / 04 / 93$ & 0900 & 550 & 8.4 & $21.5 / 19.0$ & 1.11 & 8.3 & 98 & 360 & 0.37 \\
$08 / 05 / 93$ & 1445 & 540 & 8.4 & $29.0 / 29.5$ & 0.59 & 7.0 & 104 & 360 & 0.13 \\
$09 / 22 / 93$ & 0930 & 510 & 8.4 & $25.0 / 17.5$ & 1.97 & 7.6 & 91 & 340 & 0.43 \\
$12 / 07 / 93$ & 0950 & 440 & 8.4 & $3.0 / 1.5$ & 0.49 & 12.4 & 101 & 290 & 0.88 \\
$03 / 09 / 94$ & 0755 & 420 & 8.4 & $2.5 / 5.5$ & 0.90 & 9.0 & 82 & 280 & 0.90 \\
$06 / 07 / 94$ & 0745 & 500 & 8.2 & $19.0 / 18.0$ & 1.16 & 8.2 & 99 & 330 & 0.10 \\
$09 / 13 / 94$ & 0840 & 570 & 8.1 & $23.0 / 19.5$ & 3.19 & 7.2 & 90 & 380 & 0.47 \\
$02 / 09 / 95$ & 1125 & 430 & 8.4 & $16.5 / 8.5$ & 1.60 & 9.4 & 92 & 280 & 0.90 \\
$06 / 07 / 95$ & 0935 & 470 & 8.3 & $21.0 / 21.5$ & 1.08 & 7.2 & 93 & 310 & 0.18 \\
$10 / 03 / 95$ & 1155 & 450 & 8.1 & $24.0 / 22.0$ & 2.68 & -- & --- & 300 & 0.38 \\
\hline
\end{tabular}

${ }^{1}$ Value was marked with a "?" by the Bureau of Land Management.

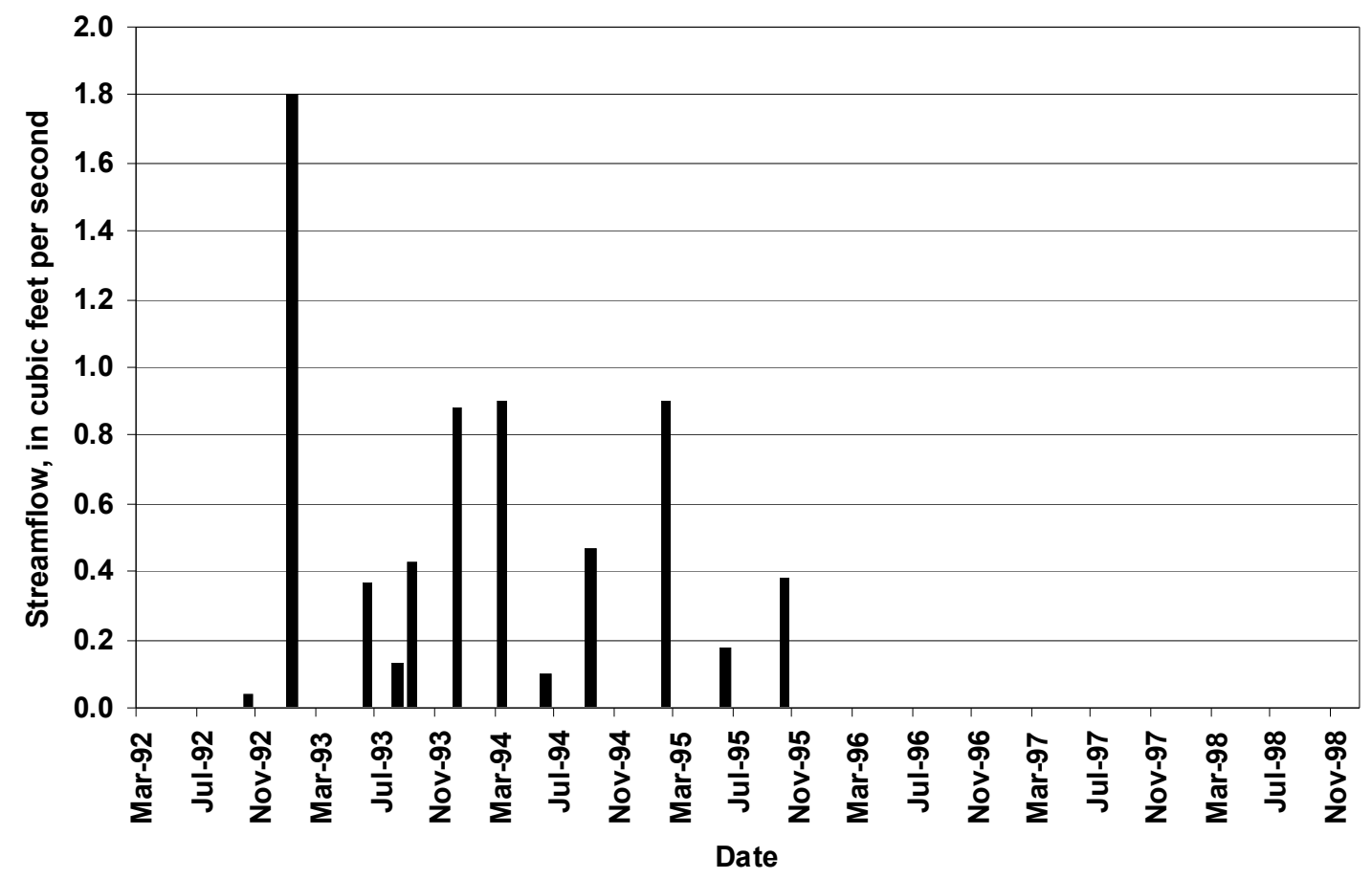


Site LA2, Little Ash Creek, Arizona

$\left[\mu \mathrm{S} / \mathrm{cm}\right.$, microsiemens per centimeter; ${ }^{\circ} \mathrm{C}$, degrees Celsius; NTU, nephelometric turbidity units; $\mathrm{mg} / \mathrm{L}$, milligrams per liter; ppm, parts per million; ft $3 / \mathrm{s}, \mathrm{cubic}$ feet per second; e, estimated; ---, not reported]

\begin{tabular}{|c|c|c|c|c|c|c|c|c|c|}
\hline Date & Time & $\begin{array}{c}\text { Specific } \\
\text { conductance } \\
(\mu \mathrm{S} / \mathrm{cm})\end{array}$ & pH & $\begin{array}{c}\text { Air/water } \\
\text { temperature } \\
\left({ }^{\circ} \mathrm{C}\right)\end{array}$ & $\begin{array}{l}\text { Turbidity } \\
\text { (NTU) }\end{array}$ & $\begin{array}{c}\text { Dissolved } \\
\text { oxygen } \\
\text { (mg/L) }\end{array}$ & $\begin{array}{c}\text { Dissolved } \\
\text { oxygen } \\
\text { (percent } \\
\text { saturation) }\end{array}$ & $\begin{array}{c}\text { Dissolved } \\
\text { solids } \\
\text { (ppm) }\end{array}$ & $\begin{array}{c}\text { Discharge } \\
\left(\mathrm{ft}^{3} / \mathbf{s}\right)\end{array}$ \\
\hline $10 / 05 / 92$ & 1345 & 490 & 8.4 & $27.0 / 20.0$ & --- & $19.2 ?$ & --- & 340 & e. 22 \\
\hline $01 / 25 / 93$ & 1200 & 420 & 8.4 & $12.0 / 7.0$ & 0.62 & 8.0 & 75 & 280 & 2.16 \\
\hline 06/04/93 & 1000 & 550 & 8.3 & $28.0 / 19.0$ & 1.28 & 8.1 & 99 & 360 & 0.69 \\
\hline 08/05/93 & 1530 & 580 & 8.0 & $27.0 / 24.0$ & 0.54 & 4.3 & 58 & 380 & 0.29 \\
\hline $09 / 22 / 93$ & 1145 & 520 & 8.5 & $31.0 / 22.0$ & 1.65 & 7.1 & 93 & 340 & 0.53 \\
\hline $12 / 07 / 93$ & 1110 & 470 & 8.6 & $16.0 / 6.5$ & 0.52 & 10.9 & 101 & 310 & 1.16 \\
\hline 03/09/94 & 0840 & 460 & 8.4 & 7.0/7.5 & 0.73 & 10.4 & 100 & 300 & 1.27 \\
\hline 06/07/94 & 0830 & 590 & 8.1 & $25.5 / 17.0$ & 0.72 & 7.5 & 88 & 390 & 0.30 \\
\hline 09/13/94 & 0905 & 610 & 8.0 & $25.0 / 21.0$ & 1.81 & 7.3 & 94 & 400 & 0.69 \\
\hline 02/09/95 & 1030 & 450 & 8.4 & $15.5 / 8.5$ & 1.73 & 10.3 & 100 & 300 & 1.16 \\
\hline 06/07/95 & 0945 & 510 & 8.2 & $21.0 / 20.0$ & 0.89 & 7.7 & 96 & 340 & 0.28 \\
\hline 10/03/95 & 1225 & 480 & 8.1 & $25.0 / 23.0$ & 2.12 & --- & --- & 320 & 0.53 \\
\hline $11 / 04 / 98$ & 1045 & 500 & 8.3 & $17.0 / 12.0$ & --- & --- & --- & 330 & 0.60 \\
\hline
\end{tabular}

${ }^{1}$ Value was marked with a "?" by the Bureau of Land Management.

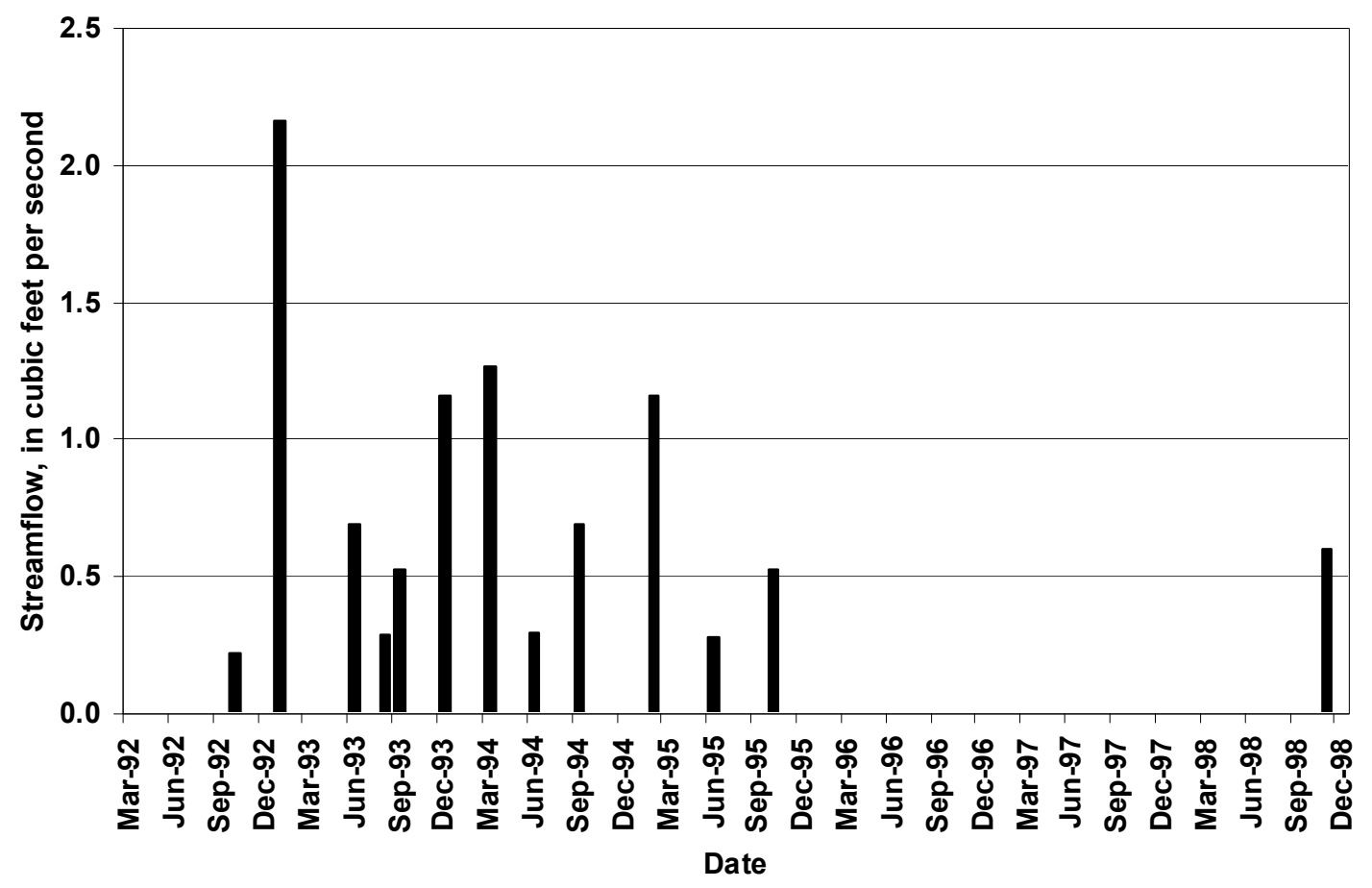




\section{Hydrologic Characteristics of the Agua Fria National Monument, Central Arizona, Reconnaissance Study}

Site SC1, Sycamore Creek, Arizona

$\left[\mu \mathrm{S} / \mathrm{cm}\right.$, microsiemens per centimeter; ${ }^{\circ} \mathrm{C}$, degrees Celsius; NTU, nephelometric turbidity units; $\mathrm{mg} / \mathrm{L}$, milligrams per liter; ppm, parts per million; $\mathrm{ft}^{3} / \mathrm{s}, \mathrm{cubic}$ feet per second; ---, not reported]

\begin{tabular}{|c|c|c|c|c|c|c|c|c|c|}
\hline Date & Time & $\begin{array}{c}\text { Specific } \\
\text { conductance } \\
(\mu \mathrm{S} / \mathrm{cm})\end{array}$ & $\mathrm{pH}$ & $\begin{array}{c}\text { Air/water } \\
\text { temperature } \\
\left({ }^{\circ} \mathrm{C}\right)\end{array}$ & $\begin{array}{c}\text { Turbidity } \\
\text { (NTU) }\end{array}$ & $\begin{array}{c}\text { Dissolved } \\
\text { oxygen } \\
\text { (mg/L) }\end{array}$ & $\begin{array}{c}\text { Dissolved } \\
\text { oxygen } \\
\text { (percent } \\
\text { saturation) }\end{array}$ & $\begin{array}{l}\text { Dissolved } \\
\text { solids } \\
\text { (ppm) }\end{array}$ & $\begin{array}{c}\text { Discharge } \\
\left(\mathrm{ft}^{3} / \mathbf{s}\right)\end{array}$ \\
\hline $08 / 19 / 92$ & 1230 & 472 & 8.2 & $33.0 / 29.5$ & --- & ${ }^{17} 7.7 ?$ & --- & 320 & 0.17 \\
\hline $01 / 28 / 93$ & 1030 & 310 & 8.3 & $13.5 / 8.0$ & 0.85 & 8.6 & 83 & 210 & 8.90 \\
\hline $08 / 12 / 93$ & 0930 & 530 & 8.4 & $30.5 / 25.5$ & 5.70 & 7.5 & 104 & 350 & 0.57 \\
\hline $12 / 09 / 93$ & 0940 & 470 & 8.7 & $8.5 / 5.0$ & 0.65 & 11.4 & 103 & 310 & 1.95 \\
\hline 05/10/94 & 0840 & 510 & 8.3 & $15.0 / 13.0$ & 2.44 & 8.4 & 92 & 340 & 1.73 \\
\hline $10 / 26 / 94$ & 1320 & 530 & 8.3 & $30.0 / 20.0$ & 2.18 & 7.3 & 92 & 350 & 0.75 \\
\hline 06/05/95 & 1015 & 460 & 8.6 & $28.0 / 24.0$ & 0.81 & 7.0 & 97 & 300 & 1.06 \\
\hline $10 / 25 / 95$ & 0950 & 540 & 8.4 & $18.0 / 14.0$ & --- & --- & --- & 360 & 0.67 \\
\hline
\end{tabular}

${ }^{1}$ Value was marked with a "?" by the Bureau of Land Management.

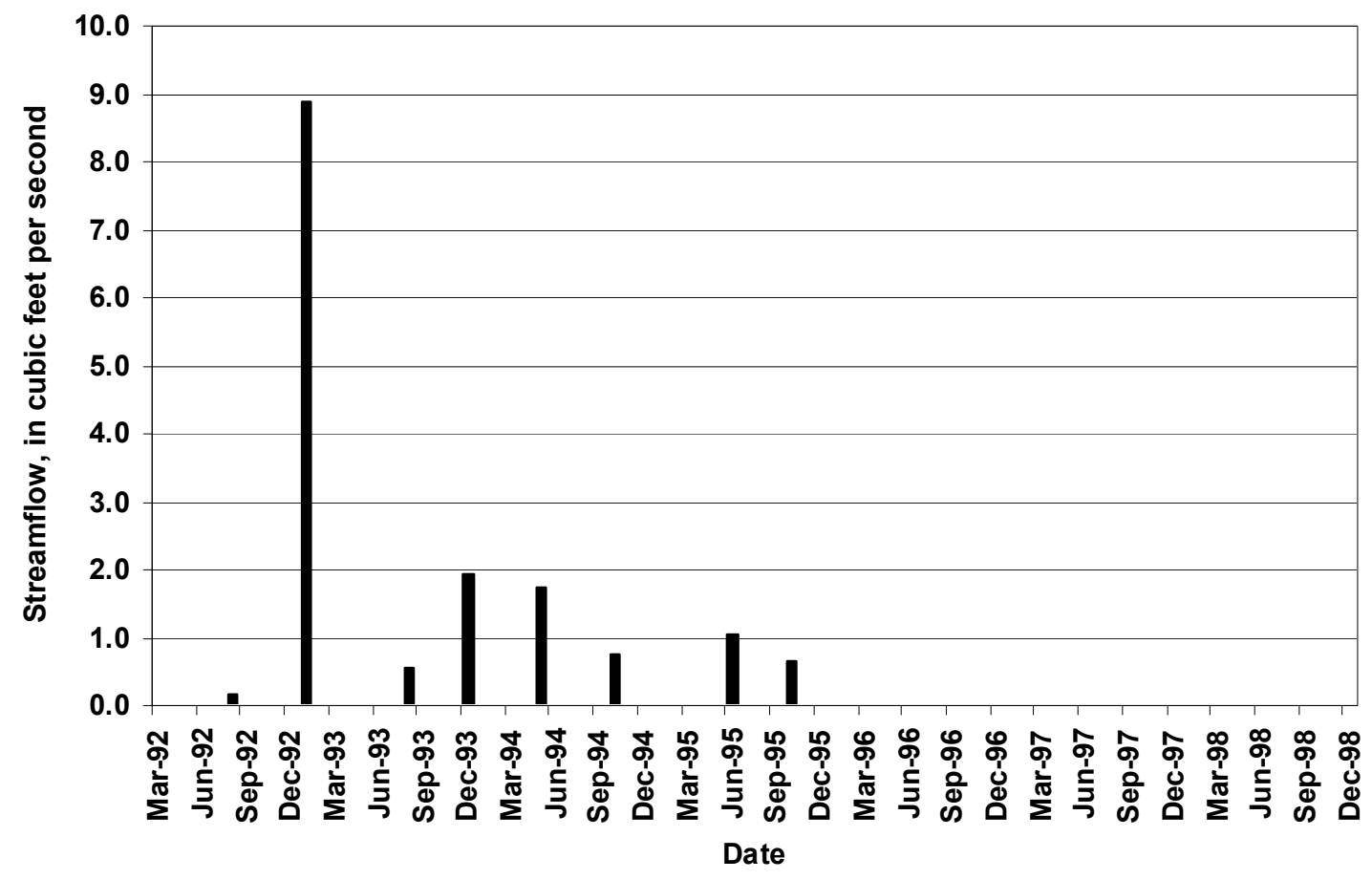


Site A2, Agua Fria River, Arizona

$\left[\mu \mathrm{S} / \mathrm{cm}\right.$, microsiemens per centimeter; ${ }^{\circ} \mathrm{C}$, degrees Celsius; NTU, nephelometric turbidity units; $\mathrm{mg} / \mathrm{L}$, milligrams per liter; ppm, parts per million; $\mathrm{ft}^{3} / \mathrm{s}$, cubic feet per second; e, estimated; ---, not reported; >, greater than]

\begin{tabular}{|c|c|c|c|c|c|c|c|c|c|}
\hline Date & Time & $\begin{array}{c}\text { Specific } \\
\text { conductance } \\
(\mu \mathrm{S} / \mathrm{cm})\end{array}$ & pH & $\begin{array}{c}\text { Air/water } \\
\text { temperature } \\
\left({ }^{\circ} \mathrm{C}\right)\end{array}$ & $\begin{array}{c}\text { Turbidity } \\
\text { (NTU) }\end{array}$ & $\begin{array}{c}\text { Dissolved } \\
\text { oxygen } \\
\text { (mg/L) }\end{array}$ & $\begin{array}{c}\text { Dissolved } \\
\text { oxygen } \\
\text { (percent } \\
\text { saturation) }\end{array}$ & $\begin{array}{l}\text { Dissolved } \\
\text { solids } \\
\text { (ppm) }\end{array}$ & $\begin{array}{c}\text { Discharge } \\
\left(\mathrm{ft}^{3} / \mathbf{s}\right)\end{array}$ \\
\hline $06 / 25 / 92$ & 1030 & 870 & 8.1 & $32.0 / 26.0$ & --- & --- & --- & 595 & 1.23 \\
\hline 07/13/92 & 0900 & 880 & 8.2 & $25.0 / 23.5$ & --- & --- & --- & 600 & 0.91 \\
\hline $07 / 31 / 92$ & 0900 & 960 & 8.2 & $26.0 / 24.5$ & --- & --- & --- & 660 & 1.1 \\
\hline 08/19/92 & 0940 & 1,015 & 8.2 & $29.0 / 27.0$ & --- & --- & --- & 694 & 1.02 \\
\hline 09/04/92 & 0815 & 785 & 8.2 & $26.0 / 20.0$ & --- & 7.7 & 96 & 539 & 2.63 \\
\hline $09 / 25 / 92$ & 0900 & 922 & 8.3 & $25.0 / 22.0$ & --- & 8.4 & 106 & 631 & 1.68 \\
\hline $10 / 20 / 92$ & 0815 & 970 & 8.3 & $18.5 / 15.5$ & --- & 9.1 & 103 & 670 & 1.50 \\
\hline $11 / 06 / 92$ & 0930 & 890 & 8.4 & $14.0 / 12.5$ & --- & 9.9 & 105 & 610 & 2.37 \\
\hline $12 / 07 / 92$ & 1100 & 670 & 8.5 & $12.0 / 11.0$ & --- & -- & --- & 460 & 5.58 \\
\hline 03/04/93 & 0930 & 530 & 8.4 & $11.0 / 9.0$ & 406.00 & 9 & 89 & 350 & e150 \\
\hline 03/18/93 & 1200 & 740 & 8.2 & 19.5/18.0 & 77.40 & 8.2 & 99 & 490 & 58.14 \\
\hline 04/19/93 & 1015 & 750 & 8.1 & $19.5 / 17.5$ & 20.30 & 7.1 & 79 & 500 & 26.61 \\
\hline 06/01/93 & 0830 & 800 & 8.4 & $22.0 / 19.5$ & 1.48 & 8.3 & 90 & 530 & 6.36 \\
\hline 07/02/93 & 1215 & 840 & 8.4 & $31.0 / 29.0$ & 1.83 & 6.7 & 99 & 550 & 2.22 \\
\hline 07/29/93 & 1430 & 840 & 8.6 & $34.0 / 28.0$ & 1.88 & -- & --- & 550 & 1.68 \\
\hline 08/31/93 & 0845 & 700 & 8.4 & $23.5 / 22.0$ & 24.00 & 8.4 & 109 & 460 & 11.4 \\
\hline $10 / 22 / 93$ & 0800 & 830 & 8.5 & $11.0 / 13.0$ & 2.79 & 9.4 & 101 & 550 & 5.58 \\
\hline $12 / 06 / 93$ & 1245 & 710 & 8.5 & $17.5 / 15.0$ & 4.34 & 8.7 & 98 & 470 & 6.73 \\
\hline $02 / 10 / 94$ & 1020 & 360 & 8.4 & $9.5 / 10.0$ & 33.00 & 9.1 & 92 & 240 & 48.29 \\
\hline $03 / 25 / 94$ & 0800 & 720 & 8.3 & $8.0 / 9.0$ & 1.02 & 10.1 & 100 & 480 & 7.14 \\
\hline 05/09/94 & 1105 & 720 & 8.2 & $19.0 / 19.0$ & 3.13 & 7.3 & 89 & 480 & 4.35 \\
\hline $06 / 15 / 94$ & 0910 & 880 & 8.5 & $26.0 / 22.5$ & 3.23 & 7.2 & 95 & 580 & 1.06 \\
\hline 08/09/94 & 0740 & 690 & 8.5 & $24.5 / 21.0$ & $>1,000$ & 6.7 & 86 & 460 & 4.92 \\
\hline $10 / 25 / 94$ & 0810 & 1,140 & 8.4 & $14.0 / 13.0$ & 2.02 & 8.0 & 89 & 750 & 1.99 \\
\hline $12 / 21 / 94$ & 1010 & 760 & 8.3 & $17.5 / 9.5$ & 1.55 & 9.0 & 90 & 500 & 3.86 \\
\hline $05 / 23 / 95$ & 1145 & 740 & 8.4 & $23.0 / 24.0$ & 1.5 & 7.1 & 95 & 490 & 4.09 \\
\hline $10 / 04 / 95$ & 0930 & 860 & 8.3 & $20.0 / 19.5$ & 1.52 & --- & --- & 570 & 3.31 \\
\hline
\end{tabular}


40 Hydrologic Characteristics of the Agua Fria National Monument, Central Arizona, Reconnaissance Study

Site A2, Agua Fria River, Arizona - Continued

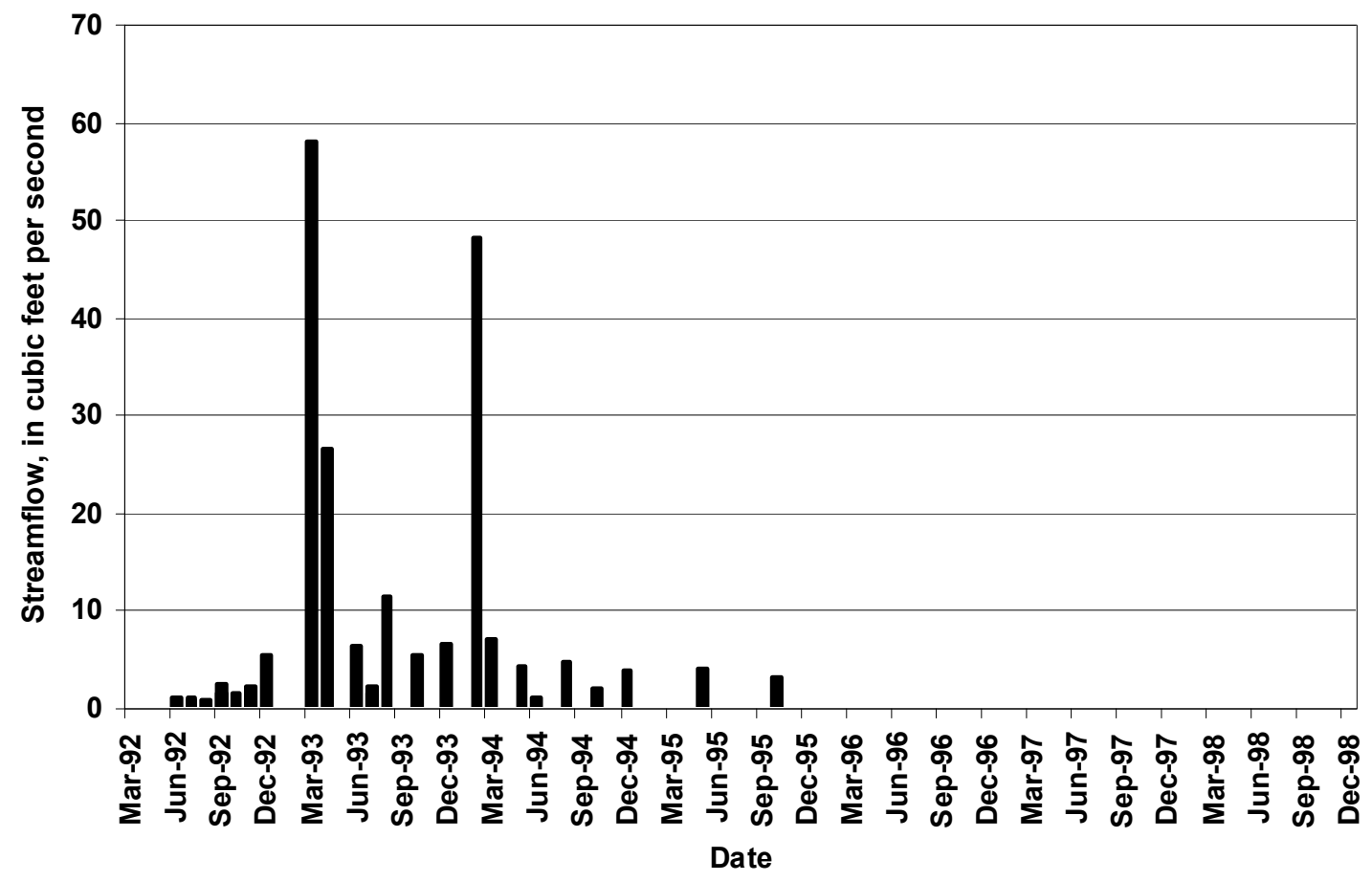


Site BB1, Big Bug Creek, Arizona

$\left[\mu \mathrm{S} / \mathrm{cm}\right.$, microsiemens per centimeter; ${ }^{\circ} \mathrm{C}$, degrees Celsius; NTU, nephelometric turbidity units; $\mathrm{mg} / \mathrm{L}$, milligrams per liter; ppm, parts per million; ft ${ }^{3} / \mathrm{s}$, cubic feet per second; ---, not reported]

\begin{tabular}{|c|c|c|c|c|c|c|c|c|c|}
\hline Date & Time & $\begin{array}{c}\text { Specific } \\
\text { conductance } \\
(\mu \mathrm{S} / \mathrm{cm})\end{array}$ & $\mathrm{pH}$ & $\begin{array}{c}\text { Air/water } \\
\text { temperature } \\
\left({ }^{\circ} \mathrm{C}\right)\end{array}$ & $\begin{array}{c}\text { Turbidity } \\
\text { (NTU) }\end{array}$ & $\begin{array}{c}\text { Dissolved } \\
\text { oxygen } \\
\text { (mg/L) }\end{array}$ & $\begin{array}{l}\text { Dissolved } \\
\text { oxygen } \\
\text { (percent } \\
\text { saturation) }\end{array}$ & $\begin{array}{l}\text { Dissolved } \\
\text { solids } \\
\text { (ppm) }\end{array}$ & $\begin{array}{c}\text { Discharge } \\
\left(\mathrm{ft}^{3} / \mathbf{s}\right)\end{array}$ \\
\hline $06 / 25 / 92$ & 1115 & 560 & 7.9 & $33.0 / 26.0$ & --- & --- & --- & 390 & 0.45 \\
\hline 07/13/92 & 0930 & 630 & 8.3 & $25.0 / 23.0$ & --- & --- & --- & 430 & 0.56 \\
\hline 07/31/92 & 0945 & 650 & 8.3 & $24.0 / 25.0$ & --- & --- & --- & 450 & 0.44 \\
\hline 08/19/92 & 1015 & 625 & 8.3 & $29.0 / 26.0$ & --- & 7.5 & 105 & 430 & 0.36 \\
\hline 09/04/92 & 0900 & 690 & 8.4 & 26.0/18.0 & --- & 8.9 & 106 & 460 & 0.56 \\
\hline 09/25/92 & 0945 & 650 & 8.3 & $25.0 / 20.0$ & --- & 8.8 & 107 & 440 & 0.30 \\
\hline 10/20/92 & 0900 & 690 & 8.5 & $17.5 / 12.0$ & --- & 9.7 & 102 & 470 & 0.29 \\
\hline $11 / 06 / 92$ & 1015 & 690 & 8.4 & $15.0 / 8.5$ & --- & 10.5 & 102 & 480 & 0.38 \\
\hline $12 / 07 / 92$ & 1200 & 650 & 8.5 & $12.0 / 8.0$ & --- & 11 & 106 & 450 & 0.36 \\
\hline 03/04/93 & 0830 & 500 & 8.4 & $11.0 / 9.0$ & 14.60 & 9.7 & 96 & 330 & 37.20 \\
\hline 04/19/93 & 1115 & 770 & 8.3 & $19.5 / 17.5$ & 0.79 & 7.8 & 93 & 510 & 5.65 \\
\hline 06/01/93 & 0930 & 820 & 8.5 & $24.0 / 18.5$ & 0.70 & 9.1 & 110 & 540 & 1.08 \\
\hline 07/02/93 & 0957 & 800 & 8.2 & $23.0 / 23.0$ & 2.76 & 8.8 & 104 & 530 & 0.77 \\
\hline 07/29/93 & 1300 & 770 & 8.7 & $29.0 / 20.5$ & 1.44 & --- & --- & 510 & 0.38 \\
\hline $08 / 31 / 93$ & 1015 & 890 & 8.0 & $24.0 / 22.5$ & 1.54 & 8.4 & 110 & 590 & 0.74 \\
\hline $10 / 22 / 93$ & 0900 & 880 & 8.6 & $12.0 / 11.0$ & 0.85 & 10.0 & 103 & 580 & 0.44 \\
\hline $12 / 06 / 93$ & 1415 & 800 & 8.4 & $17.5 / 10.5$ & 0.77 & 9.5 & 97 & 530 & 0.58 \\
\hline $02 / 10 / 94$ & 1145 & 740 & 8.4 & $12.0 / 10.0$ & 1.10 & 9.0 & 91 & 490 & 0.61 \\
\hline 03/25/94 & 0910 & 810 & 8.3 & $11.5 / 9.0$ & 1.11 & 9.2 & 91 & 530 & 0.51 \\
\hline 05/09/94 & 1145 & 790 & 8.1 & $18.0 / 18.5$ & 0.67 & 8.1 & 98 & 520 & 0.35 \\
\hline 06/15/94 & 0955 & 890 & 8.4 & $28.0 / 23.0$ & 0.88 & 7.6 & 100 & 590 & 0.07 \\
\hline 08/09/94 & 0815 & --- & --- & --- & --- & --- & --- & --- & 0.00 \\
\hline $10 / 28 / 94$ & 0840 & --- & --- & --- & --- & --- & --- & --- & 0.00 \\
\hline $12 / 21 / 94$ & 1105 & 900 & 8.3 & $18.0 / 8.0$ & 1.64 & 9.1 & 87 & 590 & 0.015 \\
\hline 05/23/95 & 1250 & 670 & 8.4 & $23.0 / 25.5$ & 1.52 & 6.5 & 90 & 440 & 0.59 \\
\hline 10/04/95 & 1040 & 760 & 8.3 & $24.0 / 17.0$ & 1.25 & --- & --- & 500 & 0.38 \\
\hline $11 / 04 / 98$ & 1430 & 700 & 8.4 & $20.0 / 20.0$ & --- & --- & --- & 460 & 0.3 \\
\hline
\end{tabular}


42 Hydrologic Characteristics of the Agua Fria National Monument, Central Arizona, Reconnaissance Study

Site BB1, Big Bug Creek, Arizona-Continued

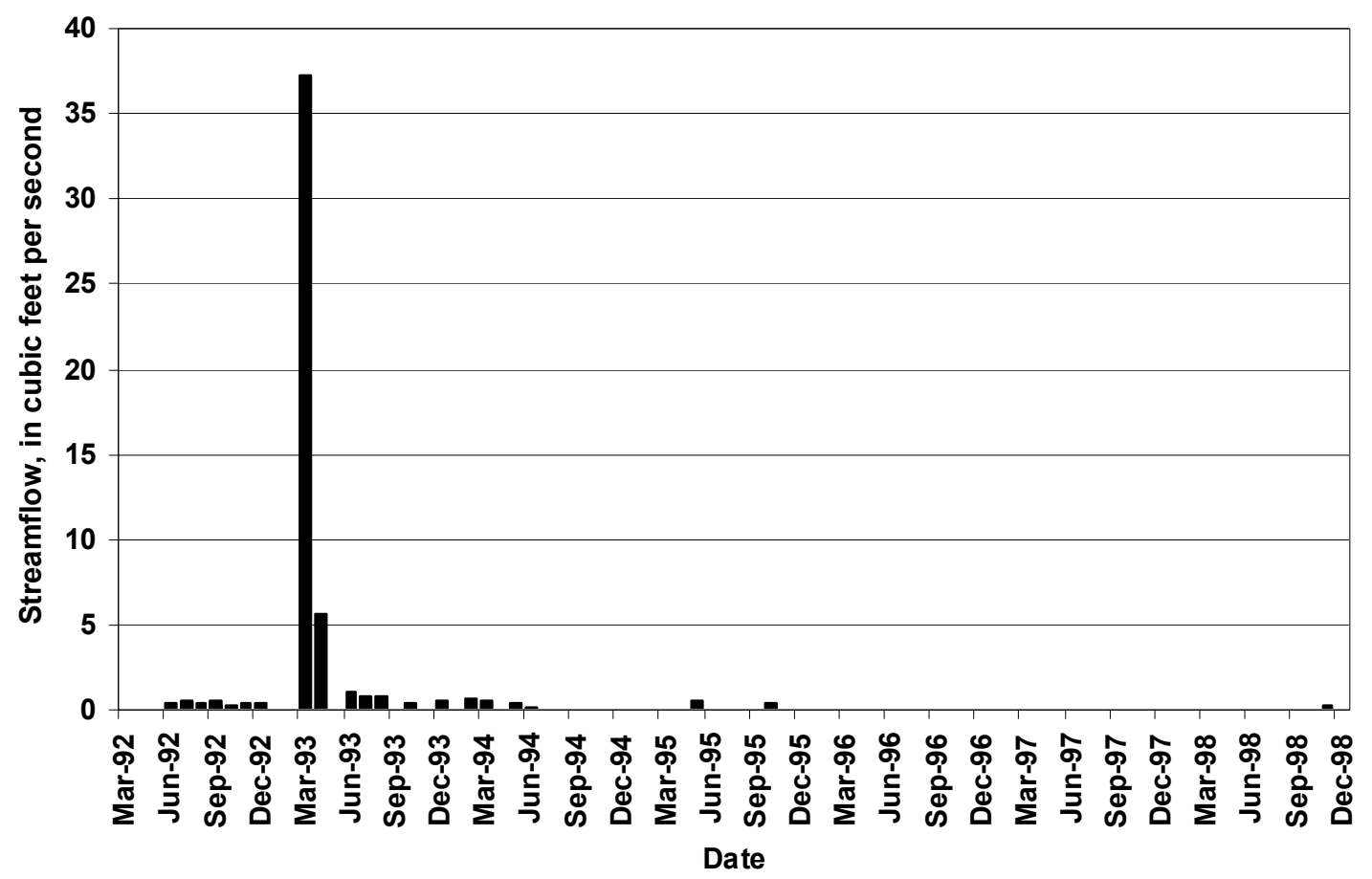


Site AN1, Antelope Creek, Arizona

$\left[\mu \mathrm{S} / \mathrm{cm}\right.$, microsiemens per centimeter; ${ }^{\circ} \mathrm{C}$, degrees Celsius; NTU, nephelometric turbidity units; $\mathrm{mg} / \mathrm{L}$, milligrams per liter; ppm, parts per million; $\mathrm{ft}^{3} / \mathrm{s}, \mathrm{cubic}$ feet per second; ---, not reported]

\begin{tabular}{|c|c|c|c|c|c|c|c|c|c|}
\hline Date & Time & $\begin{array}{c}\text { Specific } \\
\text { conductance } \\
(\mu \mathrm{S} / \mathrm{cm})\end{array}$ & pH & $\begin{array}{c}\text { Air/water } \\
\text { temperature } \\
\left({ }^{\circ} \mathrm{C}\right)\end{array}$ & $\begin{array}{l}\text { Turbidity } \\
\text { (NTU) }\end{array}$ & $\begin{array}{c}\text { Dissolved } \\
\text { oxygen } \\
\text { (mg/L) }\end{array}$ & $\begin{array}{l}\text { Dissolved } \\
\text { oxygen } \\
\text { (percent } \\
\text { saturation) }\end{array}$ & $\begin{array}{l}\text { Dissolved } \\
\text { solids } \\
\text { (ppm) }\end{array}$ & $\begin{array}{c}\text { Discharge } \\
\left(\mathrm{ft}^{3} / \mathbf{s}\right)\end{array}$ \\
\hline $09 / 30 / 94$ & 0825 & 900 & 8.2 & $23.5 / 19.0$ & 0.66 & 6.7 & 83 & 600 & 0.03 \\
\hline $12 / 21 / 94$ & 1215 & 760 & 8.3 & $19.0 / 12.0$ & 0.89 & 8.5 & 89 & 500 & 0.035 \\
\hline 02/08/95 & 1445 & 770 & 8.3 & $18.0 / 15.5$ & 1.15 & --- & --- & 510 & 0.09 \\
\hline 03/15/95 & 0840 & 810 & 8.3 & $17.0 / 14.0$ & 2.19 & --- & --- & 530 & 0.16 \\
\hline 07/13/95 & 0925 & 800 & 8.0 & $24.0 / 24.0$ & 1.85 & --- & --- & 530 & 0.024 \\
\hline $10 / 20 / 95$ & 1035 & 780 & 8.3 & $25.5 / 18.0$ & 1.50 & --- & --- & 510 & 0.056 \\
\hline 03/23/98 & 1420 & 760 & 8.3 & $27.0 / 23.0$ & -- & --- & --- & 500 & 0.055 \\
\hline $04 / 14 / 98$ & 1450 & 770 & 8.3 & $16.0 / 18.0$ & 1.03 & --- & --- & 500 & 0.099 \\
\hline
\end{tabular}

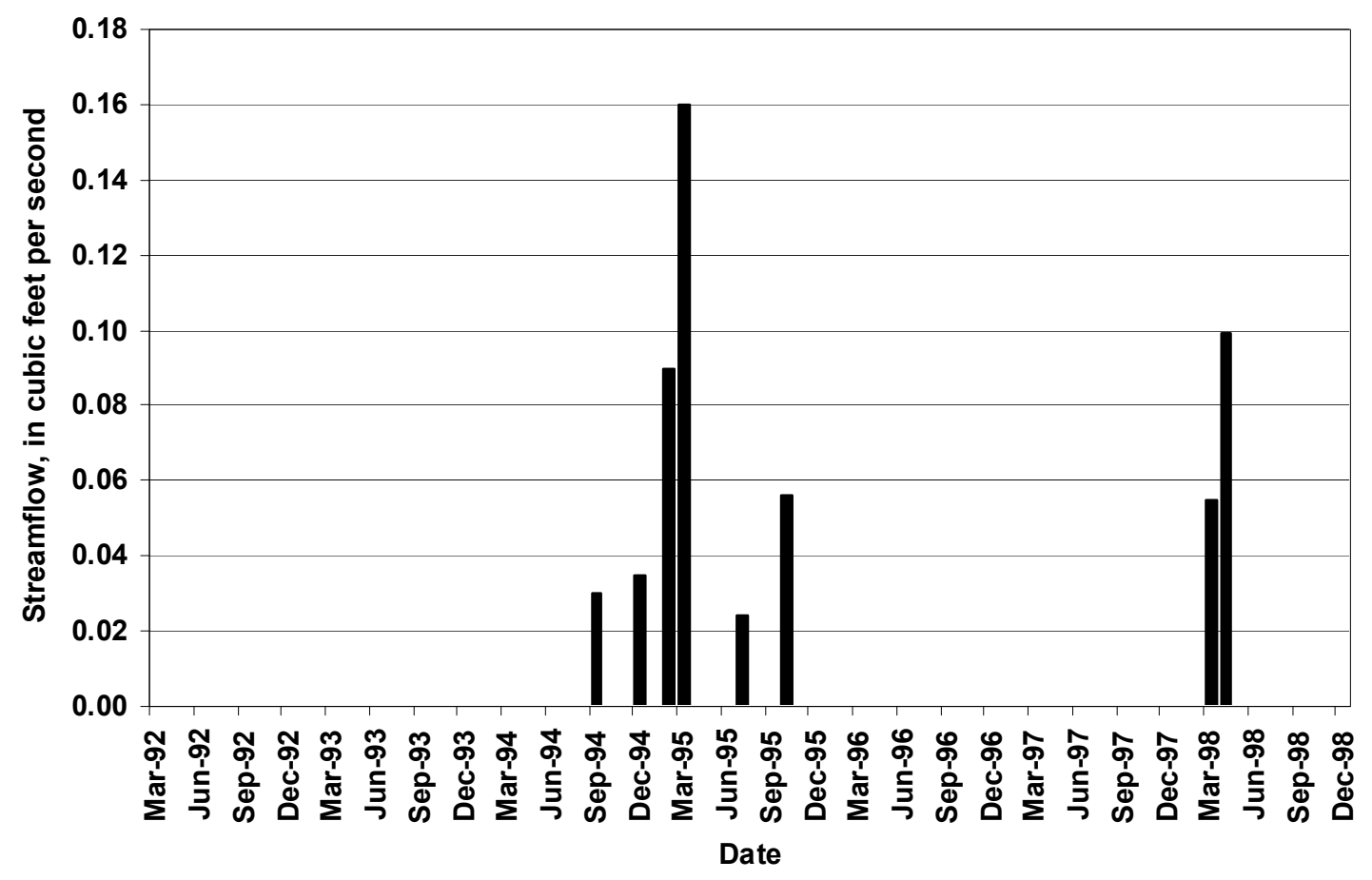




\section{Hydrologic Characteristics of the Agua Fria National Monument, Central Arizona, Reconnaissance Study}

\section{Site I1, Indian Creek, Arizona}

$\left[\mu \mathrm{S} / \mathrm{cm}\right.$, microsiemens per centimeter; ${ }^{\circ} \mathrm{C}$, degrees Celsius; NTU, nephelometric turbidity units; $\mathrm{mg} / \mathrm{L}$, milligrams per liter; ppm, parts per million; $\mathrm{ft}^{3} / \mathrm{s}, \mathrm{cubic}$ feet per second; ---, not reported]

\begin{tabular}{cccccccccc}
\hline Date & Time & $\begin{array}{c}\text { Specific } \\
\text { conductance } \\
(\mu \mathbf{S} / \mathbf{c m})\end{array}$ & $\mathbf{p H}$ & $\begin{array}{c}\text { Air/water } \\
\text { temperature } \\
\left({ }^{\circ} \mathbf{C}\right)\end{array}$ & $\begin{array}{c}\text { Turbidity } \\
(\mathbf{N T U})\end{array}$ & $\begin{array}{c}\text { Dissolved } \\
\mathbf{0 x y g e n} \\
(\mathbf{m g} / \mathbf{L})\end{array}$ & $\begin{array}{c}\text { Dissolved } \\
\text { oxygen } \\
\text { (percent } \\
\text { saturation) }\end{array}$ & $\begin{array}{c}\text { Dissolved } \\
\text { solids } \\
(\mathbf{p p m})\end{array}$ & $\begin{array}{c}\text { Discharge } \\
\left(\mathbf{f f t}^{\mathbf{3}} / \mathbf{s}\right)\end{array}$ \\
\hline $09 / 14 / 92$ & 1345 & 670 & 7.3 & $37.0 / 25.0$ & --- & --- & -- & 460 & 0.014 \\
$10 / 05 / 92$ & 1030 & 742 & 7.7 & $25.0 / 22.0$ & --- & --- & --- & 510 & 0.015 \\
$11 / 18 / 92$ & 0915 & 640 & 8.2 & $10.5 / 10.0$ & --- & 8.5 & 86 & 420 & 0.04 \\
$06 / 15 / 93$ & 0845 & 640 & 8.5 & $27.0 / 22.0$ & 1.27 & 7.8 & 102 & 420 & 0.20 \\
$09 / 02 / 93$ & 0815 & 620 & 8.3 & $23.0 / 21.5$ & 1.48 & 8.5 & 109 & 410 & 0.53 \\
$12 / 21 / 93$ & 1000 & 530 & 8.4 & $6.0 / 5.0$ & 0.53 & 11.4 & 102 & 350 & 0.58 \\
$04 / 05 / 94$ & 0840 & 580 & 8.5 & $11.5 / 12.0$ & 0.51 & 9.3 & 98 & 380 & 0.50 \\
$06 / 29 / 94$ & 0835 & 850 & 8.3 & $33.0 / 24.0$ & 1.94 & 6.5 & 88 & 560 & 0.016 \\
$10 / 27 / 94$ & 0955 & 760 & 8.3 & $20.0 / 15.5$ & 1.18 & 8.2 & 94 & 500 & 0.18 \\
\hline
\end{tabular}

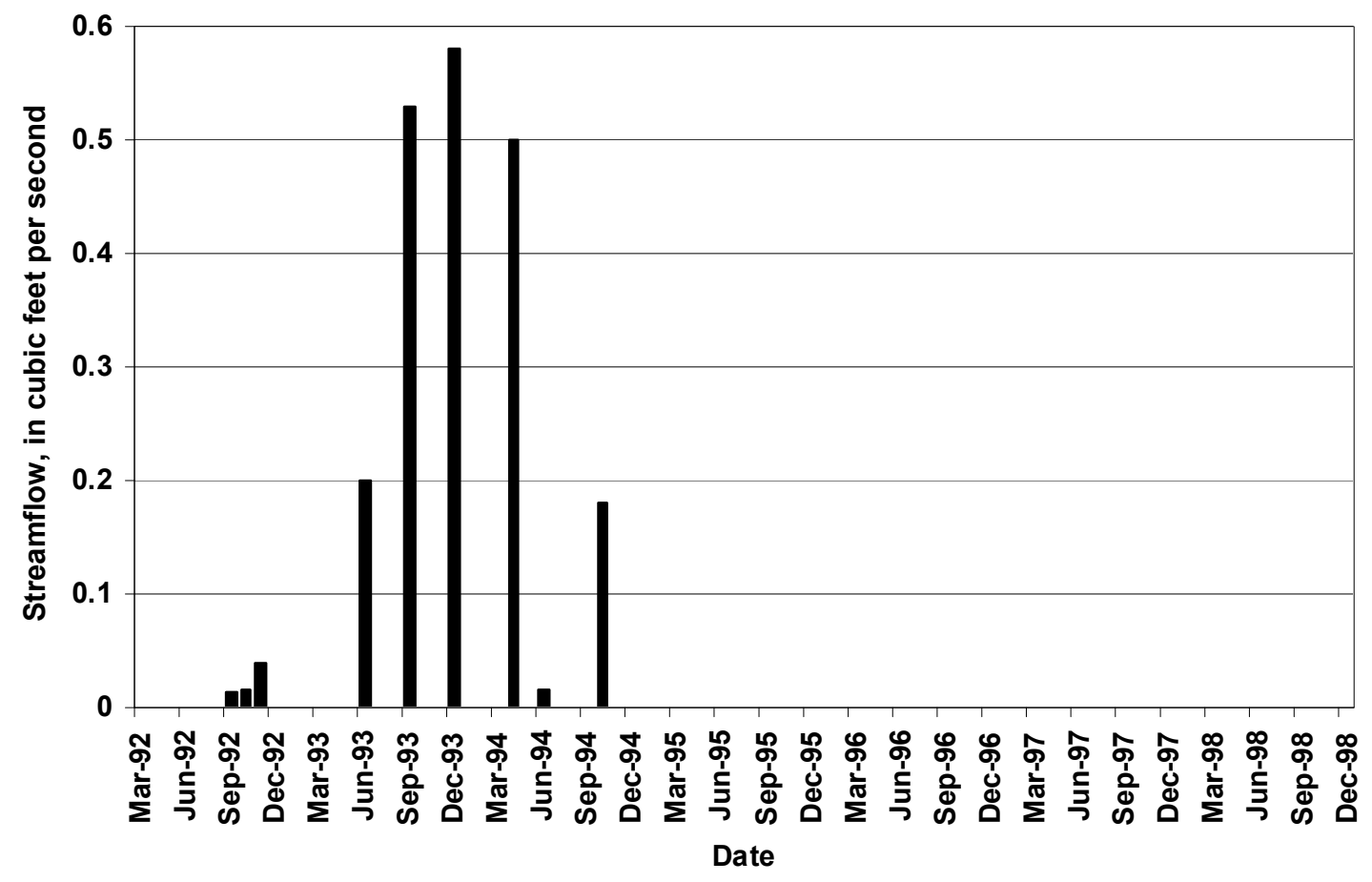


Site A3, Agua Fria River, Arizona

$\left[\mu \mathrm{S} / \mathrm{cm}\right.$, microsiemens per centimeter; ${ }^{\circ} \mathrm{C}$, degrees Celsius; NTU, nephelometric turbidity units; $\mathrm{mg} / \mathrm{L}$, milligrams per liter; ppm, parts per million; $\mathrm{ft}^{3} / \mathrm{s}$, cubic feet per second; ---, not reported; >, greater than]

\begin{tabular}{|c|c|c|c|c|c|c|c|c|c|}
\hline Date & Time & $\begin{array}{c}\text { Specific } \\
\text { conductance } \\
(\mu \mathrm{S} / \mathrm{cm})\end{array}$ & $\mathrm{pH}$ & $\begin{array}{c}\text { Air/water } \\
\text { temperature } \\
\left({ }^{\circ} \mathrm{C}\right)\end{array}$ & $\begin{array}{l}\text { Turbidity } \\
\text { (NTU) }\end{array}$ & $\begin{array}{l}\text { Dissolved } \\
\text { oxygen } \\
\text { (mg/L) }\end{array}$ & $\begin{array}{c}\text { Dissolved } \\
\text { oxygen } \\
\text { (percent } \\
\text { saturation) }\end{array}$ & $\begin{array}{l}\text { Dissolved } \\
\text { solids } \\
\text { (ppm) }\end{array}$ & $\begin{array}{c}\text { Discharge } \\
\left(\mathrm{ft}^{3} / \mathrm{s}\right)\end{array}$ \\
\hline $06 / 25 / 92$ & 1400 & 620 & 7.9 & $35.0 / 25.0$ & --- & --- & $\begin{array}{l}-- \\
\end{array}$ & 430 & 0.81 \\
\hline 07/13/92 & 1130 & 720 & 7.9 & $29.0 / 25.0$ & --- & --- & --- & 490 & 0.43 \\
\hline 08/19/92 & 0830 & 760 & 7.9 & $28.0 / 22.0$ & --- & --- & --- & 520 & 0.66 \\
\hline 09/13/92 & 1030 & 670 & 8.2 & $28.0 / 23.0$ & --- & 5.5 & 70 & 450 & 2.42 \\
\hline $10 / 20 / 92$ & 1015 & 780 & 7.8 & $24.5 / 22.5$ & --- & 5.8 & 73 & 530 & 0.51 \\
\hline 03/18/93 & 1400 & 720 & 8.3 & $20.5 / 19.5$ & 58.30 & 7.4 & 90 & 480 & 75.81 \\
\hline 04/19/93 & 1330 & 790 & 8.1 & $23.0 / 23.0$ & 20.20 & 7.2 & 94 & 520 & 39.05 \\
\hline 06/01/93 & 1200 & 820 & 8.3 & $27.0 / 25.5$ & 1.82 & 6.7 & 92 & 540 & 6.53 \\
\hline 08/04/93 & 1000 & 680 & 8.4 & $30.0 / 24.3$ & --- & --- & --- & 450 & 21.11 \\
\hline 09/16/93 & 1330 & 890 & 8.4 & $28.0 / 26.5$ & 9.76 & 6.4 & 90 & 590 & 5.03 \\
\hline $10 / 22 / 93$ & 1050 & 840 & 8.5 & $20.0 / 19.0$ & 2.50 & 7.2 & 87 & 550 & 5.92 \\
\hline $12 / 08 / 93$ & 1200 & 730 & 8.5 & $13.5 / 11.0$ & 2.59 & 9.7 & 99 & 480 & 8.93 \\
\hline $02 / 11 / 94$ & 1005 & 500 & 8.4 & $7.5 / 7.0$ & 30.50 & 10.5 & 97 & 330 & 47.10 \\
\hline $04 / 25 / 94$ & 0940 & 680 & 8.4 & $12.0 / 15.5$ & 4.51 & 8.4 & 95 & 450 & 6.16 \\
\hline 08/09/94 & 0955 & 600 & 7.8 & $30.0 / 26.0$ & $>1,000$ & 4.9 & 67 & 400 & 9.57 \\
\hline $09 / 14 / 94$ & 1225 & 970 & 8.1 & $27.5 / 28.5$ & 15.8 & 6.3 & 90 & 640 & 1.93 \\
\hline $03 / 14 / 95$ & 1405 & 480 & 8.2 & $24.0 / 20.0$ & 122 & 7.9 & 97 & 320 & 120 \\
\hline $05 / 24 / 95$ & 0930 & 720 & 8.3 & $21.5 / 20.5$ & 0.84 & 7.6 & 94 & 480 & 5.28 \\
\hline $10 / 16 / 95$ & 1455 & 790 & 8.1 & $28.0 / 22.5$ & 2.07 & --- & --- & 520 & 1.40 \\
\hline 10/09/98 & 1530 & 690 & 8.6 & $23.0 / 23.0$ & --- & --- & --- & 450 & 0.06 \\
\hline
\end{tabular}

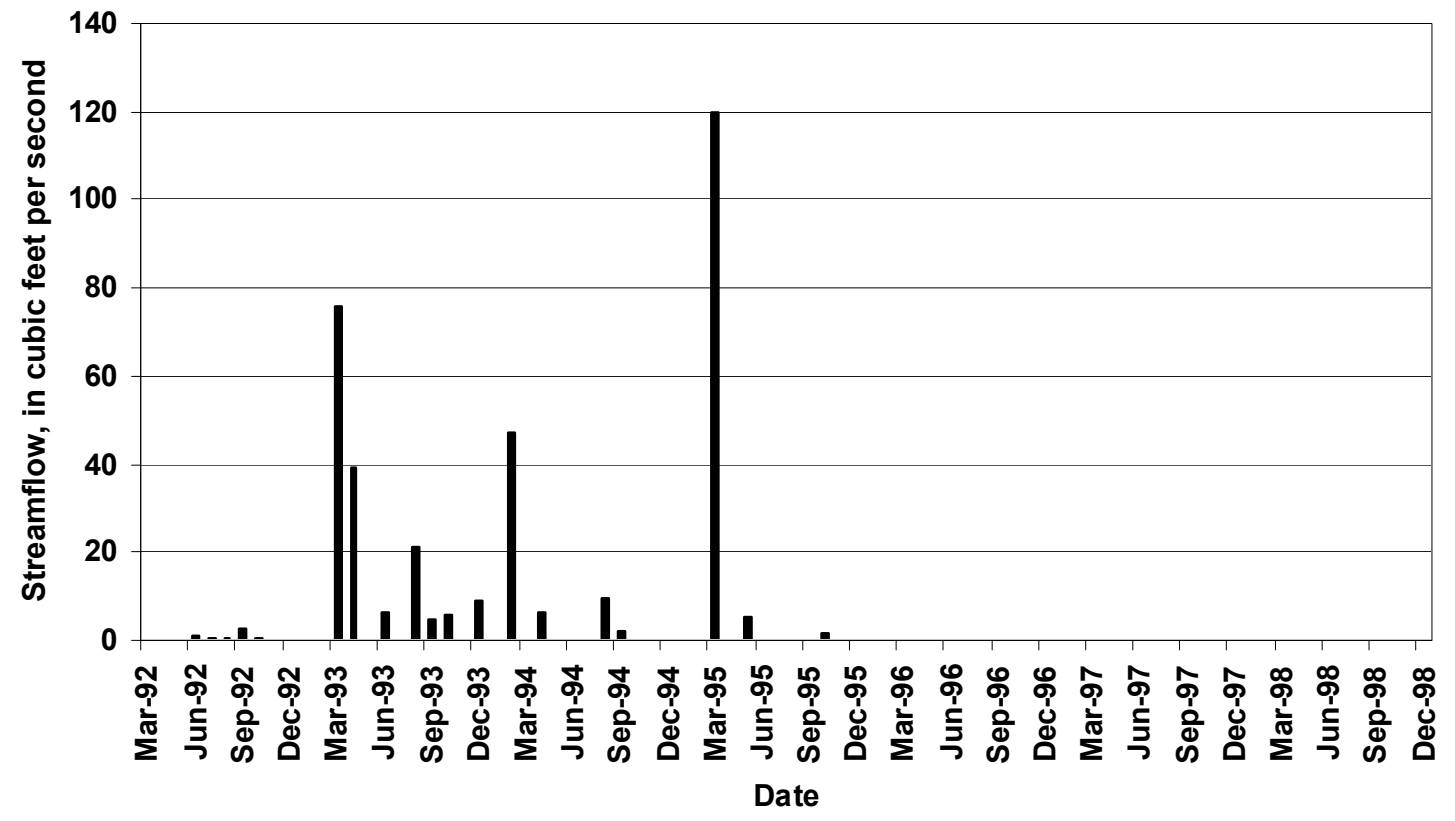


46 Hydrologic Characteristics of the Agua Fria National Monument, Central Arizona, Reconnaissance Study

Site S1, Silver Creek, Arizona

$\left[\mu \mathrm{S} / \mathrm{cm}\right.$, microsiemens per centimeter; ${ }^{\circ} \mathrm{C}$, degrees Celsius; $\mathrm{NTU}$, nephelometric turbidity units; $\mathrm{mg} / \mathrm{L}$, milligrams per liter; ppm, parts per million; $\mathrm{ft}^{3} / \mathrm{s}, \mathrm{cubic}$ feet per second; ---, not reported]

\begin{tabular}{|c|c|c|c|c|c|c|c|c|c|}
\hline Date & Time & $\begin{array}{c}\text { Specific } \\
\text { conductance } \\
(\mu \mathrm{S} / \mathrm{cm})\end{array}$ & pH & $\begin{array}{c}\text { Air/water } \\
\text { temperature } \\
\left({ }^{\circ} \mathrm{C}\right)\end{array}$ & $\begin{array}{c}\text { Turbidity } \\
\text { (NTU) }\end{array}$ & $\begin{array}{c}\text { Dissolved } \\
\text { oxygen } \\
\text { (mg/L) }\end{array}$ & $\begin{array}{l}\text { Dissolved } \\
\text { oxygen } \\
\text { (percent } \\
\text { saturation) }\end{array}$ & $\begin{array}{l}\text { Dissolved } \\
\text { solids } \\
\text { (ppm) }\end{array}$ & $\begin{array}{c}\text { Discharge } \\
\left(\mathrm{ft}^{3} / \mathrm{s}\right)\end{array}$ \\
\hline $10 / 05 / 92$ & 0830 & 630 & 8.4 & $24.0 / 16.0$ & --- & $19.3 ?$ & --- & 430 & 0.024 \\
\hline 06/01/93 & 1330 & 550 & 8.5 & $30.5 / 27.0$ & 0.69 & 7.2 & 103 & 360 & 0.48 \\
\hline $12 / 08 / 93$ & 0940 & 550 & 8.6 & $6.0 / 5.0$ & 0.30 & 11.6 & 103 & 360 & 0.47 \\
\hline 03/10/94 & 0820 & 540 & 8.40 & $6.0 / 6.5$ & 0.36 & 8.8 & 69 & 360 & 0.59 \\
\hline 06/05/94 & 0915 & 630 & 8.40 & $28.5 / 19.0$ & 0.62 & 8.0 & 98 & 420 & 0.21 \\
\hline $10 / 27 / 94$ & 1415 & 660 & 8.30 & $25.0 / 19.0$ & 1.74 & 7.6 & 96 & 440 & 0.15 \\
\hline $10 / 04 / 97$ & 1050 & 820 & 8.00 & $26.0 / 26.0$ & 3.33 & --- & --- & 540 & 0.04 \\
\hline $11 / 13 / 98$ & 1050 & 690 & 8.30 & $18.0 / 10.5$ & --- & --- & --- & 450 & 0.14 \\
\hline
\end{tabular}

${ }^{1}$ Value was marked with a "?" by the Bureau of Land Management.

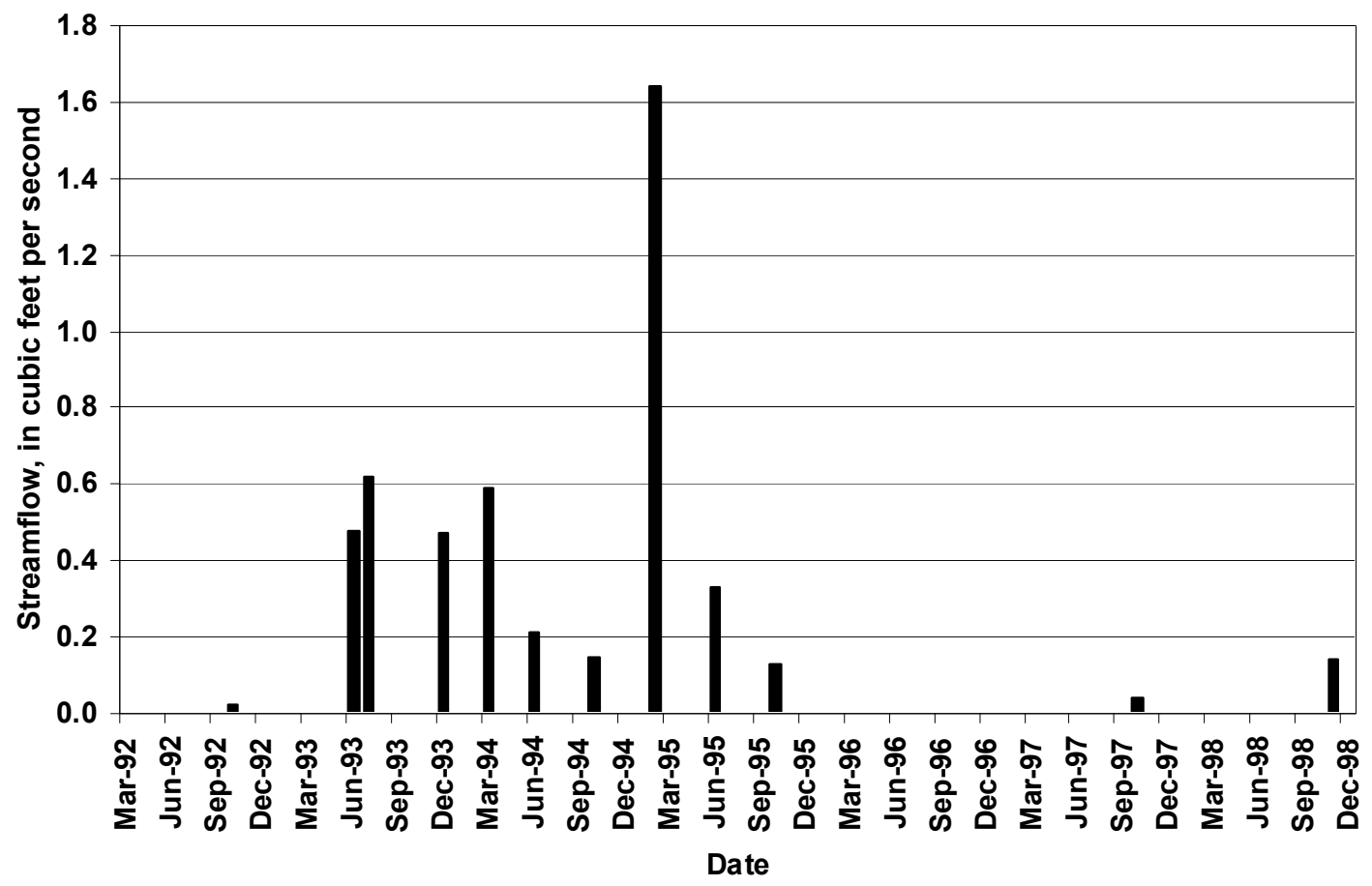


Site LR1, Larry Creek Tributary, Arizona

$\left[\mu \mathrm{S} / \mathrm{cm}\right.$, microsiemens per centimeter; ${ }^{\circ} \mathrm{C}$, degrees Celsius; NTU, nephelometric turbidity units; $\mathrm{mg} / \mathrm{L}$, milligrams per liter; ppm, parts per million; ft $\mathrm{ft}^{3} / \mathrm{s}$, cubic feet per second; ---, not reported]

\begin{tabular}{|c|c|c|c|c|c|c|c|c|c|}
\hline Date & Time & $\begin{array}{c}\text { Specific } \\
\text { conductance } \\
(\mu \mathrm{S} / \mathrm{cm})\end{array}$ & pH & $\begin{array}{c}\text { Air/water } \\
\text { temperature } \\
\left({ }^{\circ} \mathrm{C}\right)\end{array}$ & $\begin{array}{c}\text { Turbidity } \\
\text { (NTU) }\end{array}$ & $\begin{array}{c}\text { Dissolved } \\
\text { oxygen } \\
\text { (mg/L) }\end{array}$ & $\begin{array}{c}\text { Dissolved } \\
\text { oxygen } \\
\text { (percent } \\
\text { saturation) }\end{array}$ & $\begin{array}{l}\text { Dissolved } \\
\text { solids } \\
\text { (ppm) }\end{array}$ & $\begin{array}{c}\text { Discharge } \\
\left(\mathrm{ft}^{3} / \mathrm{s}\right)\end{array}$ \\
\hline $12 / 17 / 92$ & 1400 & 625 & 8.1 & $8.0 / 15.0$ & 0.20 & 5.9 & 65 & 425 & 0.07 \\
\hline $04 / 17 / 93$ & 1000 & 610 & 8.1 & $15.0 / 17.0$ & 0.85 & 7.8 & 90 & 400 & 0.33 \\
\hline $05 / 21 / 93$ & 0930 & 610 & 8.3 & $21.5 / 20.0$ & 1.16 & 7.6 & 93 & 400 & 0.18 \\
\hline 07/08/93 & 0845 & 620 & 8.0 & $26.0 / 22.0$ & 1.04 & 6.8 & 87 & 410 & 0.11 \\
\hline 09/24/93 & 0830 & 620 & 8.3 & $20.5 / 20.0$ & 1.90 & 7.9 & 97 & 410 & 0.09 \\
\hline $12 / 20 / 93$ & 1145 & 500 & 8.1 & $10.5 / 13.0$ & 0.19 & 8.9 & 94 & 330 & 0.12 \\
\hline 03/11/94 & 0830 & 540 & 8.2 & $12.0 / 15.0$ & 0.46 & 7.3 & 80 & 360 & 0.11 \\
\hline $05 / 25 / 94$ & 0830 & 590 & 8.1 & $18.5 / 18.5$ & 0.55 & 6.4 & 76 & 390 & 0.08 \\
\hline 09/14/94 & 0835 & 650 & 8.0 & $18.0 / 20.0$ & 0.47 & 7.3 & 89 & 430 & 0.05 \\
\hline $06 / 22 / 95$ & 0835 & 590 & 8.0 & $21.0 / 20.0$ & 0.62 & 7.4 & 91 & 390 & 0.06 \\
\hline
\end{tabular}

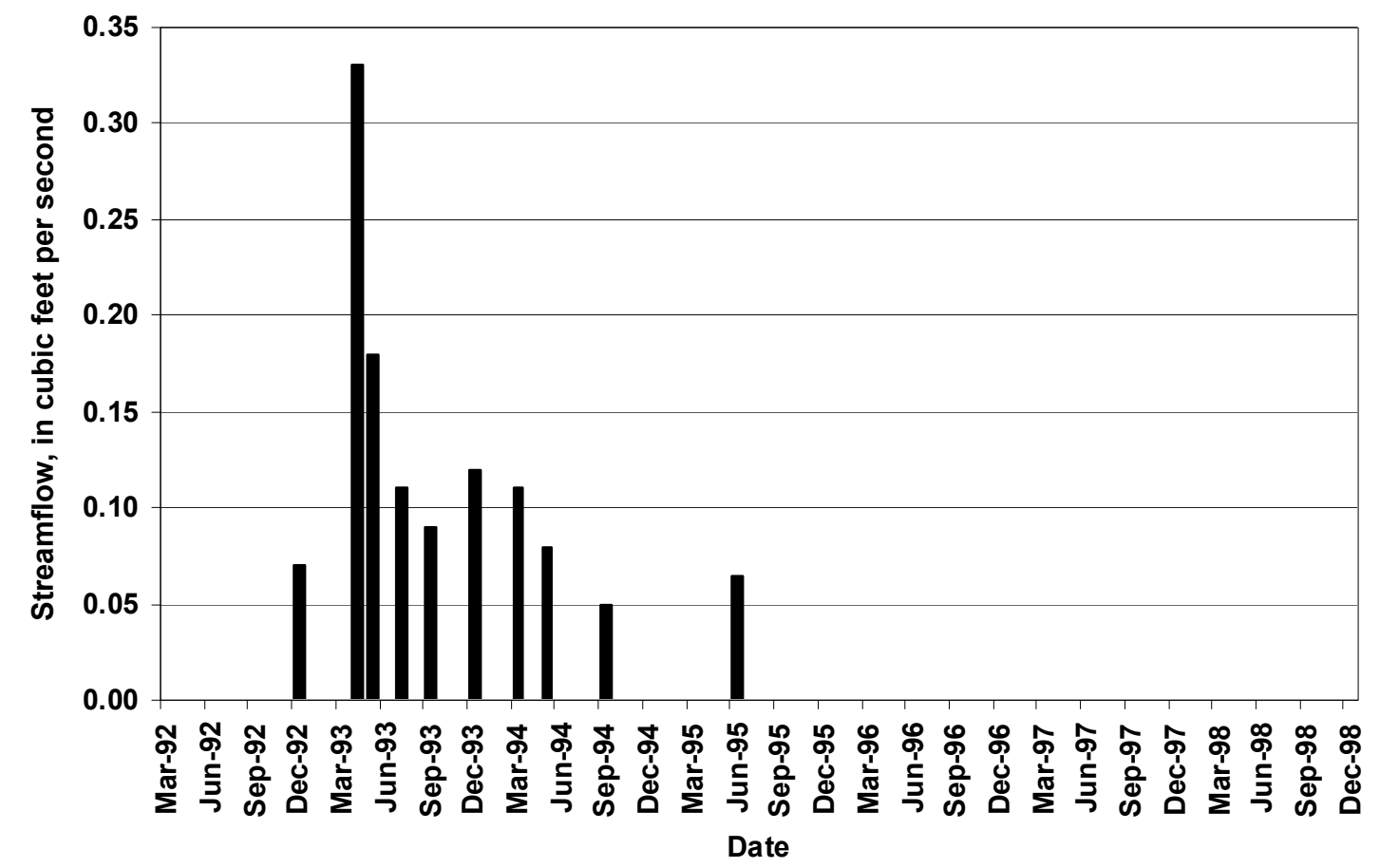


Hydrologic Characteristics of the Agua Fria National Monument, Central Arizona, Reconnaissance Study

Site LR2, Larry Creek, Arizona

$\left[\mu \mathrm{S} / \mathrm{cm}\right.$, microsiemens per centimeter; ${ }^{\circ} \mathrm{C}$, degrees Celsius; NTU, nephelometric turbidity units; $\mathrm{mg} / \mathrm{L}$, milligrams per liter; ppm, parts per million; $\mathrm{ft}^{3} / \mathrm{s}, \mathrm{cubic}$ feet per second]

\begin{tabular}{cccccccccc}
\hline Date & Time & $\begin{array}{c}\text { Specific } \\
\text { conductance } \\
(\mu \mathbf{S} / \mathbf{c m})\end{array}$ & $\mathbf{p H}$ & $\begin{array}{c}\text { Air/water } \\
\text { temperature } \\
\left({ }^{\circ} \mathbf{C}\right)\end{array}$ & $\begin{array}{c}\text { Turbidity } \\
(\mathbf{N T U})\end{array}$ & $\begin{array}{c}\text { Dissolved } \\
\mathbf{0 x y g e n} \\
(\mathbf{m g} / \mathbf{L})\end{array}$ & $\begin{array}{c}\text { Dissolved } \\
\mathbf{0 x y g e n} \\
(\mathbf{p e r c e n t} \\
\mathbf{s a t u r a t i o n})\end{array}$ & $\begin{array}{c}\text { Dissolved } \\
\mathbf{s o l i d s} \\
(\mathbf{p p m})\end{array}$ & $\begin{array}{c}\text { Discharge } \\
\left(\mathbf{f t}^{3} / \mathbf{s}\right)\end{array}$ \\
\hline $12 / 17 / 92$ & 1200 & 775 & 8.6 & $9.0 / 9.5$ & 0.45 & 10.6 & 102 & 530 & 0.015 \\
\hline
\end{tabular}

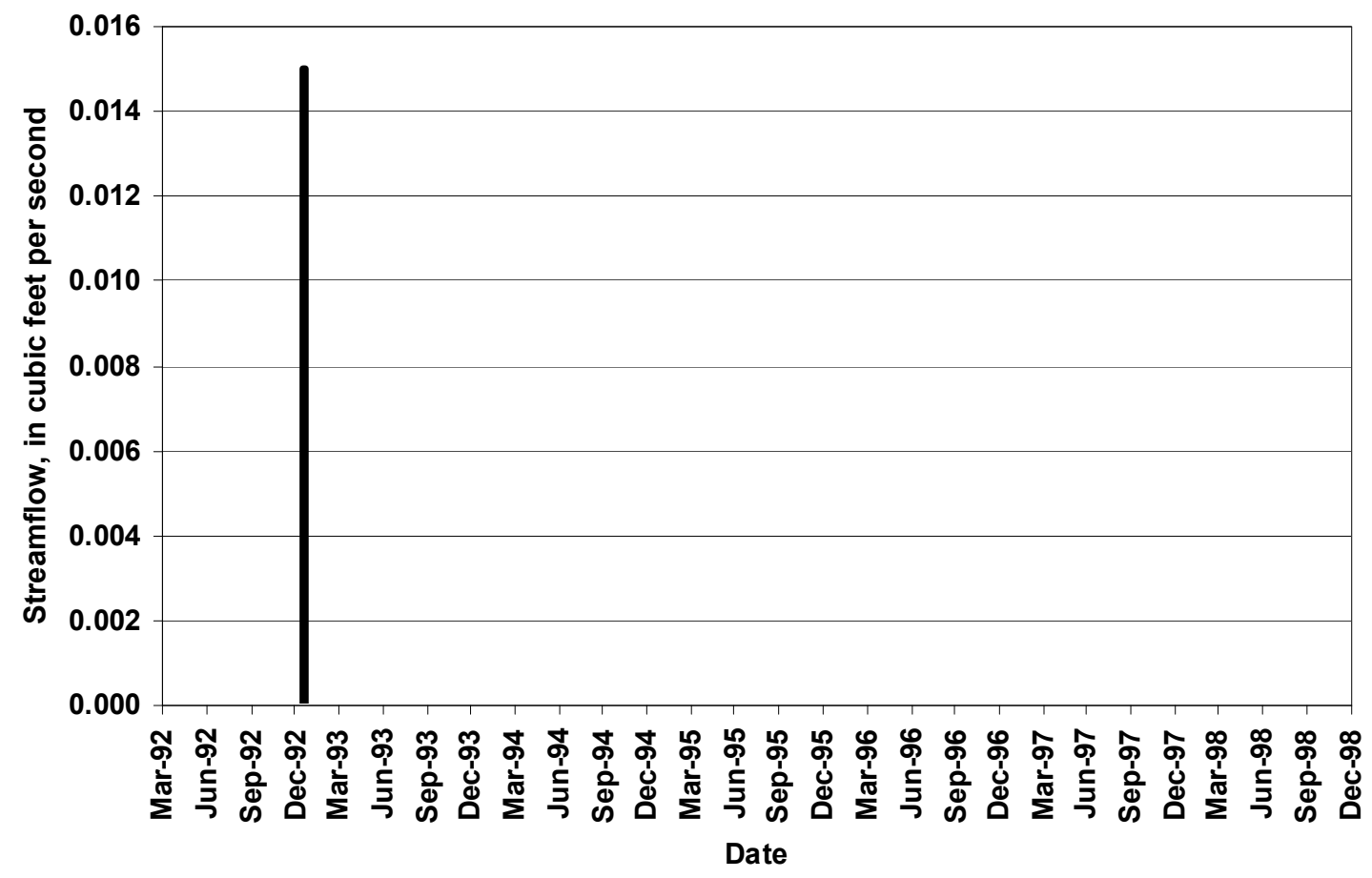


Site BCC1, Black Canyon Creek, Arizona

$\left[\mu \mathrm{S} / \mathrm{cm}\right.$, microsiemens per centimeter; ${ }^{\circ} \mathrm{C}$, degrees Celsius; NTU, nephelometric turbidity units; $\mathrm{mg} / \mathrm{L}$, milligrams per liter; ppm, parts per million; ft ${ }^{3} / \mathrm{s}$, cubic feet per second; ---, not reported]

\begin{tabular}{|c|c|c|c|c|c|c|c|c|c|}
\hline Date & Time & $\begin{array}{c}\text { Specific } \\
\text { conductance } \\
(\mu \mathrm{S} / \mathrm{cm})\end{array}$ & pH & $\begin{array}{c}\text { Air/water } \\
\text { temperature } \\
\left({ }^{\circ} \mathrm{C}\right)\end{array}$ & $\begin{array}{l}\text { Turbidity } \\
\text { (NTU) }\end{array}$ & $\begin{array}{c}\text { Dissolved } \\
\text { oxygen } \\
\text { (mg/L) }\end{array}$ & $\begin{array}{l}\text { Dissolved } \\
\text { oxygen } \\
\text { (percent } \\
\text { saturation) }\end{array}$ & $\begin{array}{l}\text { Dissolved } \\
\text { solids } \\
\text { (ppm) }\end{array}$ & $\begin{array}{c}\text { Discharge } \\
\left(\mathrm{ft}^{3} / \mathrm{s}\right)\end{array}$ \\
\hline $03 / 19 / 93$ & 1200 & 670 & 8.4 & $22.0 / 15.5$ & 0.94 & 9.1 & 99 & 440 & 78.18 \\
\hline 04/20/93 & 1130 & 770 & 8.3 & $25.0 / 19.0$ & 0.49 & 8.5 & 99 & 510 & 26.58 \\
\hline $06 / 02 / 93$ & 0835 & 850 & 8.1 & $25.5 / 20.5$ & 0.76 & 8.2 & 99 & 560 & 4.03 \\
\hline 07/01/93 & 1415 & 760 & 8.6 & $33.0 / 31.0$ & 0.98 & 7.2 & 104 & 500 & 1.33 \\
\hline 08/04/93 & 1300 & 730 & 8.9 & $31.0 / 30.2$ & 0.65 & 7.0 & 112 & 480 & 1.17 \\
\hline 09/01/93 & 1300 & 810 & 8.5 & $33.5 / 32.0$ & 3.67 & 7.2 & 106 & 530 & 2.40 \\
\hline 09/28/93 & 0930 & 800 & 8.5 & $28.0 / 19.5$ & 1.11 & 8.8 & 104 & 530 & 1.58 \\
\hline $10 / 23 / 93$ & 1200 & 860 & 8.6 & $23.0 / 18.5$ & 0.93 & 8.7 & 100 & 570 & 2.37 \\
\hline $12 / 05 / 93$ & 1430 & 780 & 8.8 & $21.0 / 13.5$ & 1.71 & 9.7 & 101 & 510 & 4.38 \\
\hline $02 / 11 / 94$ & 1155 & 400 & 8.4 & 13.0/9.5 & 14.00 & 9.9 & 94 & 260 & 42.92 \\
\hline 03/08/94 & 1115 & 710 & 8.5 & $16.0 / 13.0$ & 0.94 & 9.3 & 96 & 470 & 8.88 \\
\hline 04/01/94 & 1445 & 720 & 8.7 & $27.0 / 23.0$ & 0.69 & 8.0 & 100 & 480 & 6.80 \\
\hline 05/06/94 & 1145 & 970 & 8.1 & $27.5 / 22.0$ & 1.03 & 7.6 & 95 & 640 & 2.04 \\
\hline 06/03/94 & 0735 & 1,020 & 8.3 & $25.0 / 19.0$ & 0.97 & 7.9 & 93 & 670 & 1.70 \\
\hline 07/01/94 & 0740 & 1,190 & 8.2 & $29.5 / 25.0$ & 1.16 & 7.2 & 93 & 790 & 0.99 \\
\hline 08/04/94 & 0735 & 1,230 & 8.3 & $25.0 / 24.0$ & 2.65 & --- & --- & 810 & 1.12 \\
\hline 09/11/94 & 0720 & 1,100 & 8.2 & $22.5 / 22.5$ & 4.88 & 5.2 & 65 & 730 & 4.73 \\
\hline $10 / 02 / 94$ & 1010 & 1,170 & 8.3 & $27.0 / 19.0$ & 1.36 & 8.5 & 100 & 770 & 0.53 \\
\hline $11 / 10 / 94$ & 1635 & 1,020 & 8.3 & $22.0 / 16.5$ & 1.09 & 8.5 & 95 & 670 & 0.61 \\
\hline $12 / 14 / 94$ & 1230 & 1,010 & 8.4 & $15.0 / 10.5$ & 0.62 & 9.7 & 95 & 670 & 0.96 \\
\hline 05/24/95 & 1140 & 610 & 8.6 & $23.0 / 21.5$ & 1.56 & 8.1 & 100 & 400 & 3.00 \\
\hline 07/26/95 & 0850 & --- & --- & --- & --- & --- & --- & --- & 0.00 \\
\hline 03/24/97 & 1400 & 410 & 8.4 & $26.0 / 20.0$ & 0.97 & --- & --- & 270 & 2.58 \\
\hline $10 / 15 / 97$ & 1130 & 19 & 7.9 & 27.5/--- & --- & --- & --- & 490 & 0.03 \\
\hline $10 / 30 / 97$ & 1120 & 420 & 8.3 & $19.0 / 8.0$ & --- & --- & --- & 270 & 2.12 \\
\hline 05/07/98 & 1050 & 360 & 8.6 & $19.0 / 8.0$ & 0.43 & --- & --- & 230 & 6.61 \\
\hline 06/12/98 & 1140 & 560 & 8.1 & $28.5 / 25.0$ & 1.47 & --- & --- & 360 & 0.00 \\
\hline $10 / 20 / 98$ & 0920 & 540 & 8.7 & $20.0 / 14.5$ & --- & --- & --- & 350 & 0.00 \\
\hline
\end{tabular}


50 Hydrologic Characteristics of the Agua Fria National Monument, Central Arizona, Reconnaissance Study

Site BCC1, Black Canyon Creek, Arizona—Continued

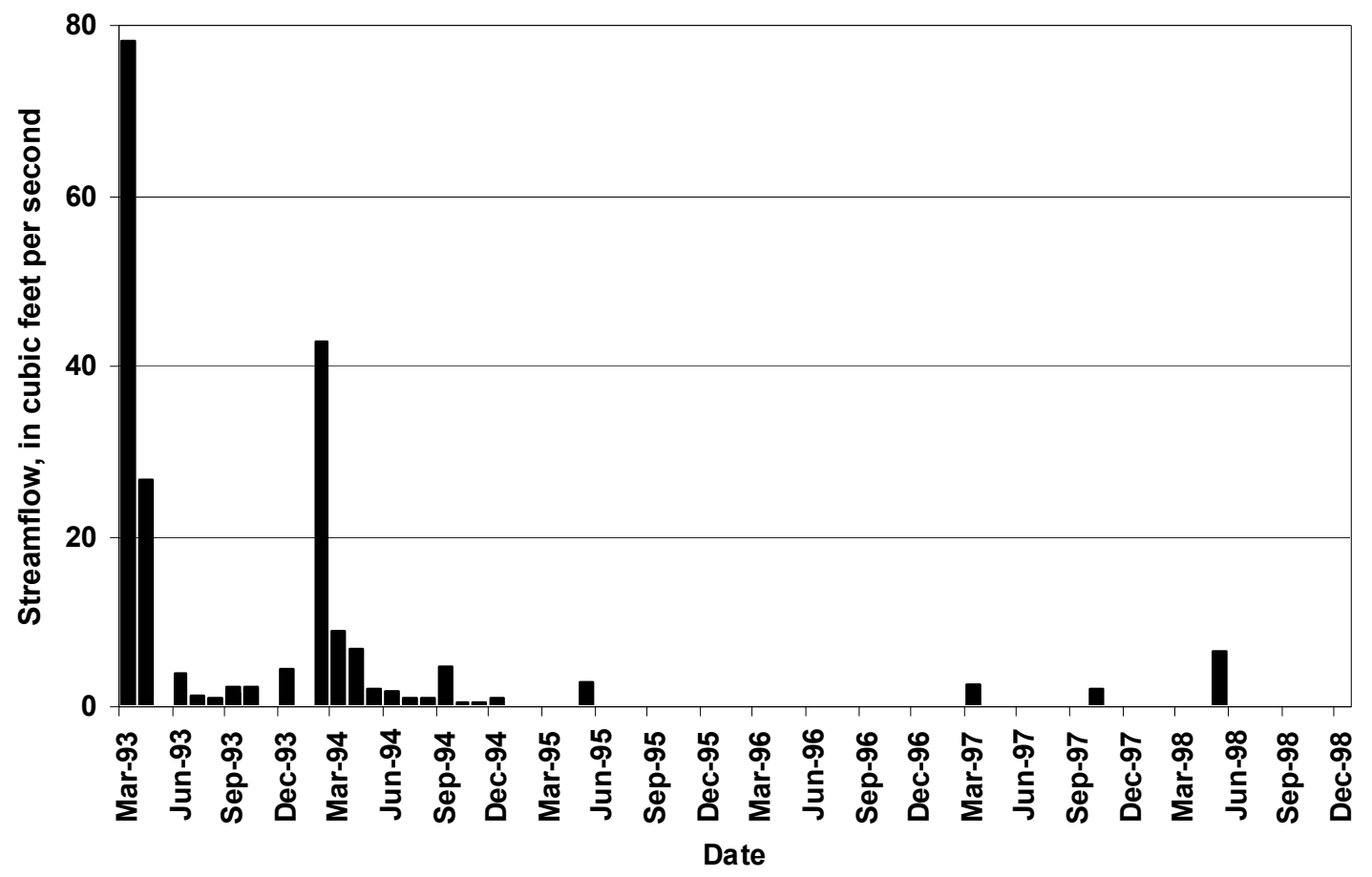


Site BCC2, Black Canyon Creek, Arizona

$\left[\mu \mathrm{S} / \mathrm{cm}\right.$, microsiemens per centimeter; ${ }^{\circ} \mathrm{C}$, degrees Celsius; NTU, nephelometric turbidity units; $\mathrm{mg} / \mathrm{L}$, milligrams per liter; ppm, parts per million; $\mathrm{ft}^{3} / \mathrm{s}, \mathrm{cubic}$ feet per second; e, estimated; ---, not reported; sl, slightly; v, very]

\begin{tabular}{|c|c|c|c|c|c|c|c|c|c|}
\hline Date & Time & $\begin{array}{c}\text { Specific } \\
\text { conductance } \\
(\mu \mathrm{S} / \mathrm{cm})\end{array}$ & $\mathrm{pH}$ & $\begin{array}{c}\text { Air/water } \\
\text { temperature } \\
\left({ }^{\circ} \mathrm{C}\right)\end{array}$ & $\begin{array}{c}\text { Turbidity }{ }^{1} \\
\text { (NTU) }\end{array}$ & $\begin{array}{c}\text { Dissolved } \\
\text { oxygen } \\
\text { (mg/L) }\end{array}$ & $\begin{array}{l}\text { Dissolved } \\
\text { oxygen } \\
\text { (percent } \\
\text { saturation) }\end{array}$ & $\begin{array}{l}\text { Dissolved } \\
\text { solids } \\
\text { (ppm) }\end{array}$ & $\begin{array}{c}\text { Discharge } \\
\left(\mathrm{ft}^{3} / \mathrm{s}\right)\end{array}$ \\
\hline $03 / 13 / 92$ & 1030 & 150 & 8.1 & $18.0 / 12.0$ & cloudy & 9.4 & 104 & 100 & 226.00 \\
\hline 03/25/92 & 0845 & 260 & 8.4 & $13.1 / 12.7$ & clear & --- & --- & 170 & 52.50 \\
\hline $03 / 31 / 92$ & 1230 & 180 & 8.3 & $13.0 / 15.0$ & clear & --- & --- & 120 & 131.70 \\
\hline 04/10/92 & 0915 & 230 & 8.2 & 19.0/16.5 & clear & --- & --- & 150 & 44.10 \\
\hline $04 / 23 / 92$ & 1340 & 360 & 8.4 & $31.0 / 25.5$ & clear & --- & --- & 240 & 8.40 \\
\hline 05/07/92 & 1105 & 350 & 8.3 & 28.5/23.0 & sl cloudy & --- & --- & 230 & 14.40 \\
\hline 05/21/92 & 1000 & --- & --- & --- & --- & --- & --- & --- & 0.00 \\
\hline 06/05/92 & 0730 & 500 & --- & $23.0 / 21.0$ & clear & --- & --- & 270 & 0.05 \\
\hline 06/25/92 & 0915 & --- & --- & --- & --- & --- & --- & --- & 0.00 \\
\hline 07/30/92 & 1600 & --- & --- & --- & --- & --- & --- & --- & 0.00 \\
\hline 08/19/92 & 0815 & --- & --- & --- & --- & --- & --- & --- & 0.00 \\
\hline 09/25/92 & 0900 & --- & --- & --- & --- & --- & --- & --- & 0.00 \\
\hline 10/20/92 & 1100 & --- & --- & --- & --- & --- & --- & --- & 0.00 \\
\hline $11 / 07 / 92$ & 1700 & --- & --- & --- & --- & --- & --- & --- & 0.00 \\
\hline $12 / 08 / 92$ & 1230 & 295 & 8.5 & $11.0 / 9.5$ & v cloudy & --- & --- & 200 & e80 \\
\hline $01 / 07 / 93$ & 1715 & 110 & 8.4 & $13.5 / 11.5$ & 896 & --- & --- & 73 & $\mathrm{e} 1,000$ \\
\hline $02 / 03 / 93$ & 1100 & 390 & 8.2 & $15.0 / 13.0$ & 4.5 & 10.6 & 100 & 260 & 102.00 \\
\hline
\end{tabular}

${ }^{1}$ Some entries are descriptive rather than NTU values.

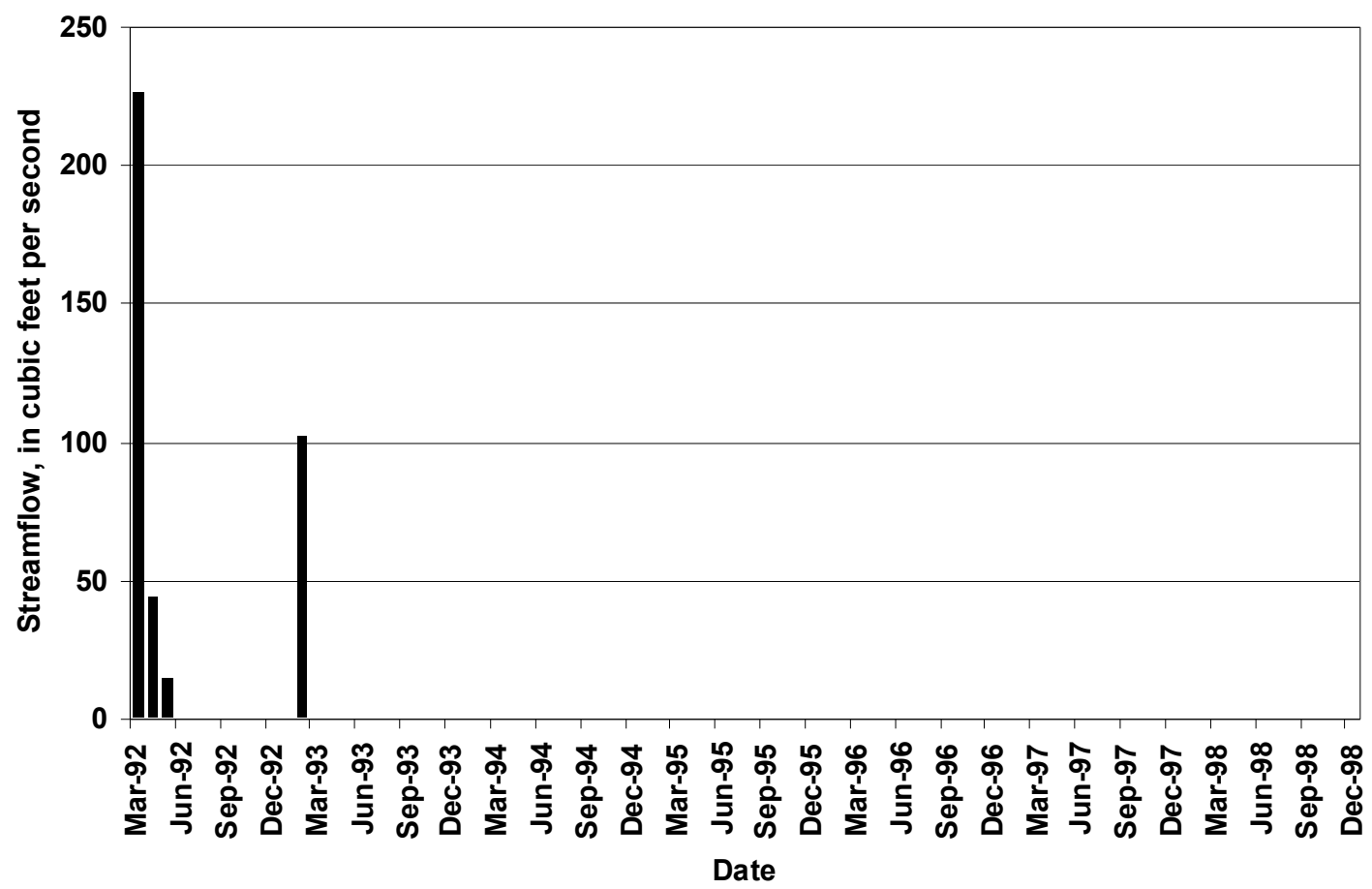




\section{Hydrologic Characteristics of the Agua Fria National Monument, Central Arizona, Reconnaissance Study}

Site A5, Agua Fria River, Arizona

$\left[\mu \mathrm{S} / \mathrm{cm}\right.$, microsiemens per centimeter; ${ }^{\circ} \mathrm{C}$, degrees Celsius; NTU, nephelometric turbidity units; $\mathrm{mg} / \mathrm{L}$, milligrams per liter; ppm, parts per million; ft ${ }^{3} / \mathrm{s}$, cubic feet per second; e, estimated; ---, not reported; sl, slightly]

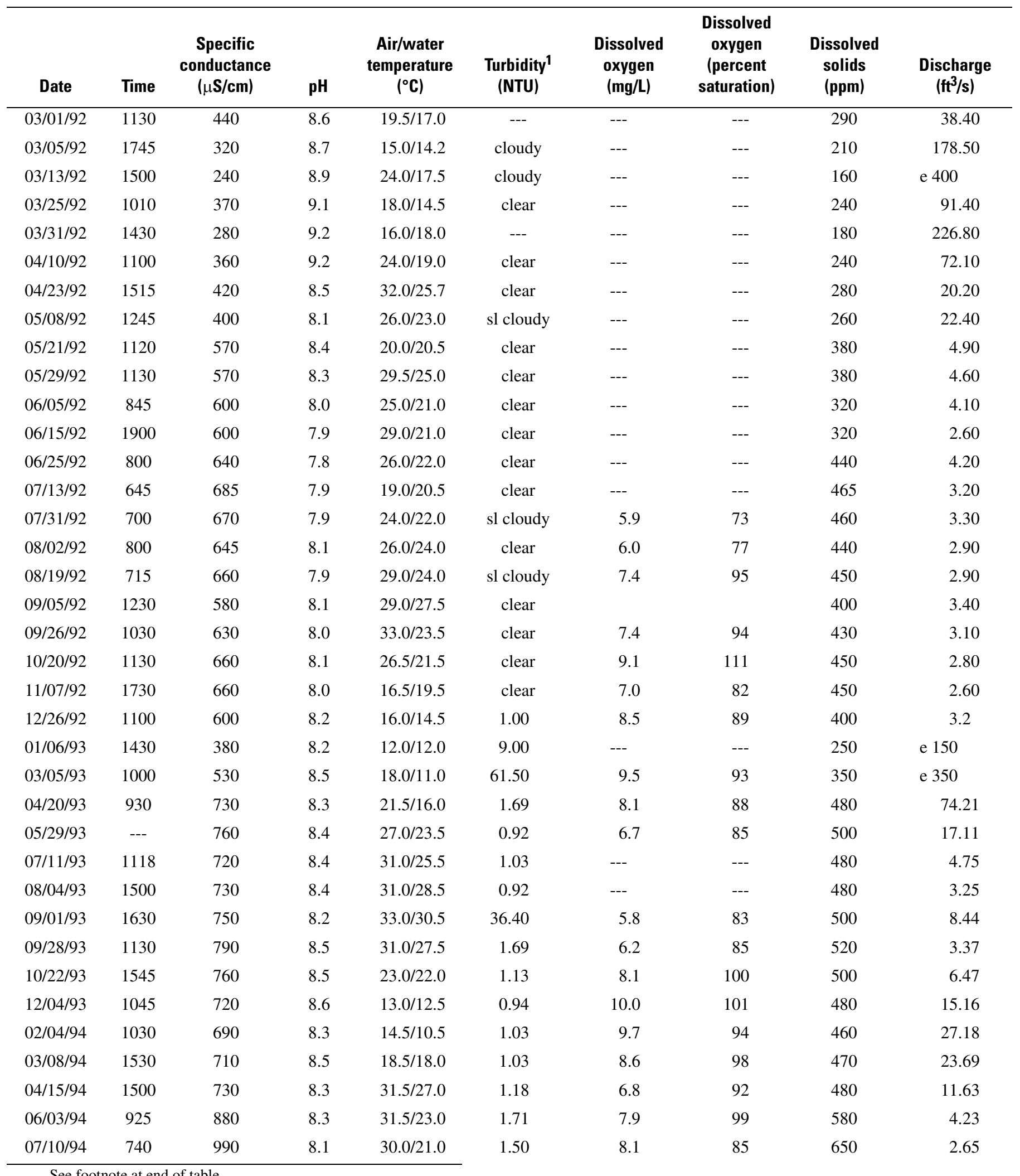




\begin{tabular}{|c|c|c|c|c|c|c|c|c|c|}
\hline Date & Time & $\begin{array}{c}\text { Specific } \\
\text { conductance } \\
(\mu \mathrm{S} / \mathrm{cm})\end{array}$ & pH & $\begin{array}{c}\text { Air/water } \\
\text { temperature } \\
\left({ }^{\circ} \mathrm{C}\right)\end{array}$ & $\begin{array}{c}\text { Turbidity }{ }^{1} \\
\text { (NTU) }\end{array}$ & $\begin{array}{c}\text { Dissolved } \\
\text { oxygen } \\
\text { (mg/L) }\end{array}$ & $\begin{array}{c}\text { Dissolved } \\
\text { oxygen } \\
\text { (percent } \\
\text { saturation) }\end{array}$ & $\begin{array}{l}\text { Dissolved } \\
\text { solids } \\
\text { (ppm) }\end{array}$ & $\begin{array}{c}\text { Discharge } \\
\left(\mathrm{ft}^{3} / \mathrm{s}\right)\end{array}$ \\
\hline $08 / 09 / 94$ & 1155 & 910 & 8.2 & $34.0 / 30.5$ & 2.30 & --- & --- & 600 & 2.59 \\
\hline 09/13/94 & 1510 & 780 & 8.0 & $33.0 / 28.5$ & 401.00 & 6.9 & 96 & 510 & e 20.5 \\
\hline $05 / 15 / 95$ & 900 & 670 & 8.6 & $24.0 / 20.0$ & 1.96 & 7.8 & 93 & 440 & 9.7 \\
\hline $06 / 27 / 95$ & 925 & 720 & 8.1 & $29.0 / 22.0$ & 1.02 & --- & --- & 480 & 4.02 \\
\hline $07 / 26 / 95$ & 1020 & 720 & 8.1 & $34.0 / 24.0$ & 1.10 & --- & --- & 480 & 2.86 \\
\hline 03/12/97 & 1415 & 410 & 8.4 & $30.0 / 22.0$ & 5.32 & --- & --- & 270 & 34.06 \\
\hline 06/09/98 & 1130 & 660 & 8.5 & $27.0 / 22.5$ & 0.43 & --- & --- & 430 & 2.41 \\
\hline $10 / 08 / 98$ & 1025 & 640 & 8.3 & $26.0 / 20.0$ & --- & --- & --- & 420 & 2.37 \\
\hline
\end{tabular}

${ }^{1}$ Some entries are descriptive rather than NTU values.

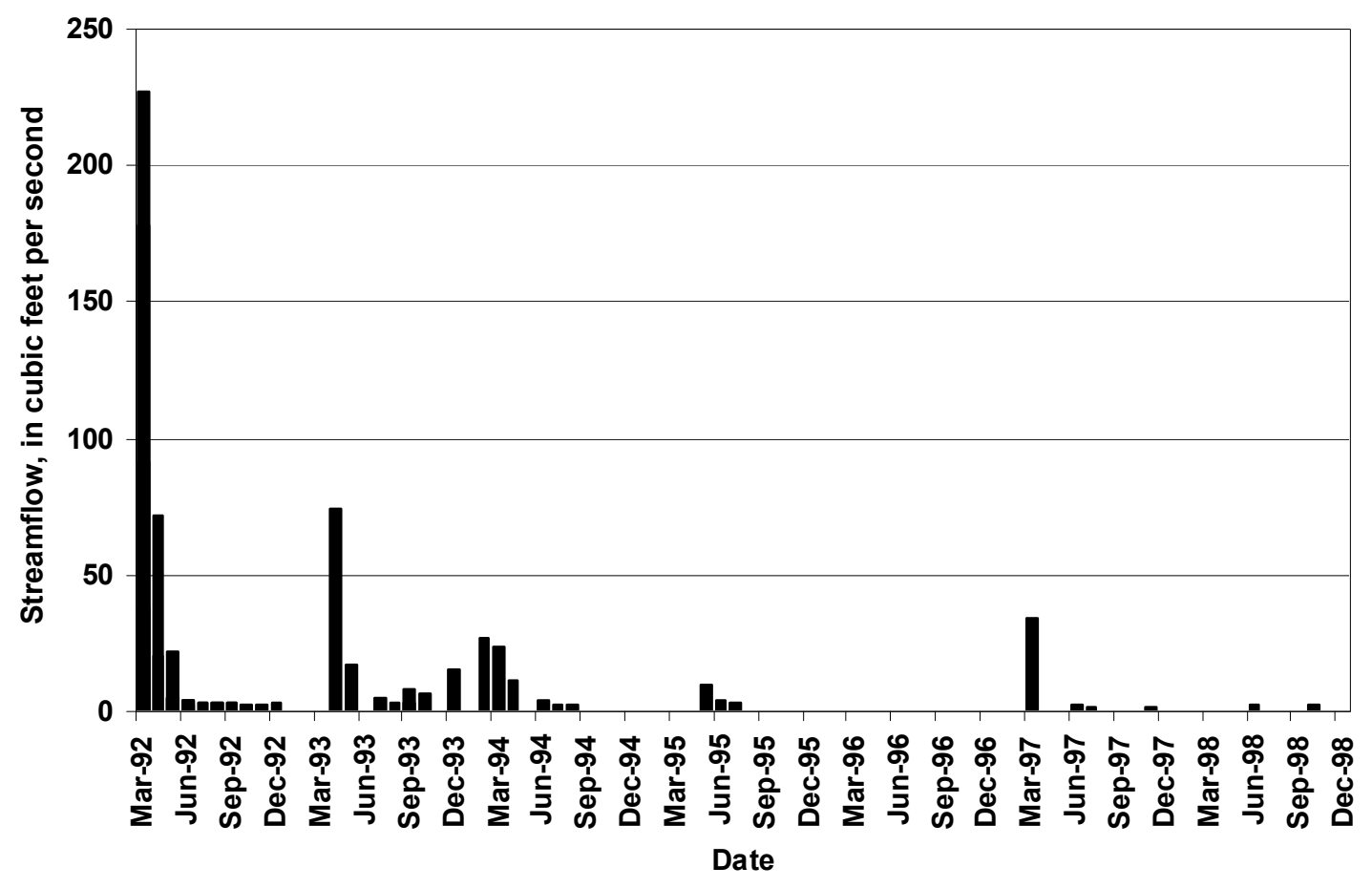


This page left blank intentionally. 
This page left blank intentionally. 


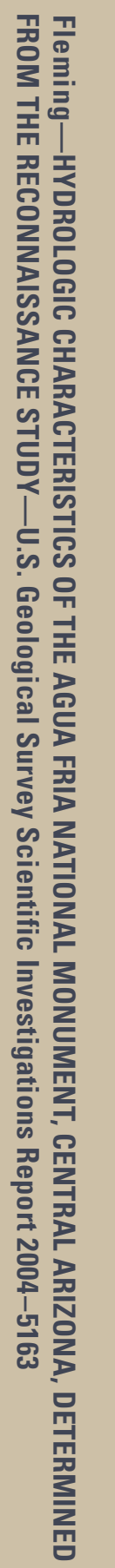

(3) Printed on recycled paper 